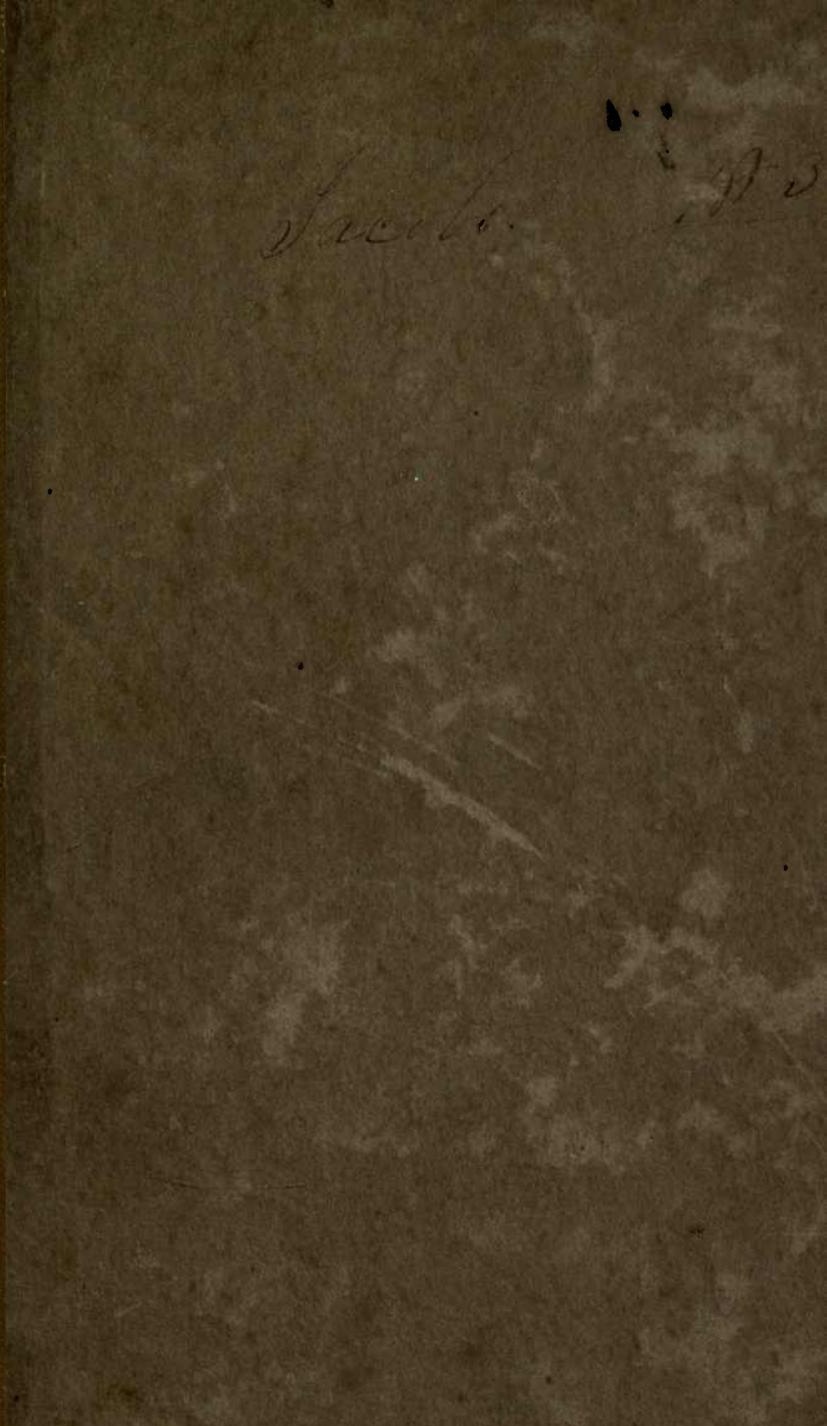

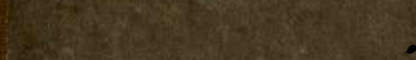




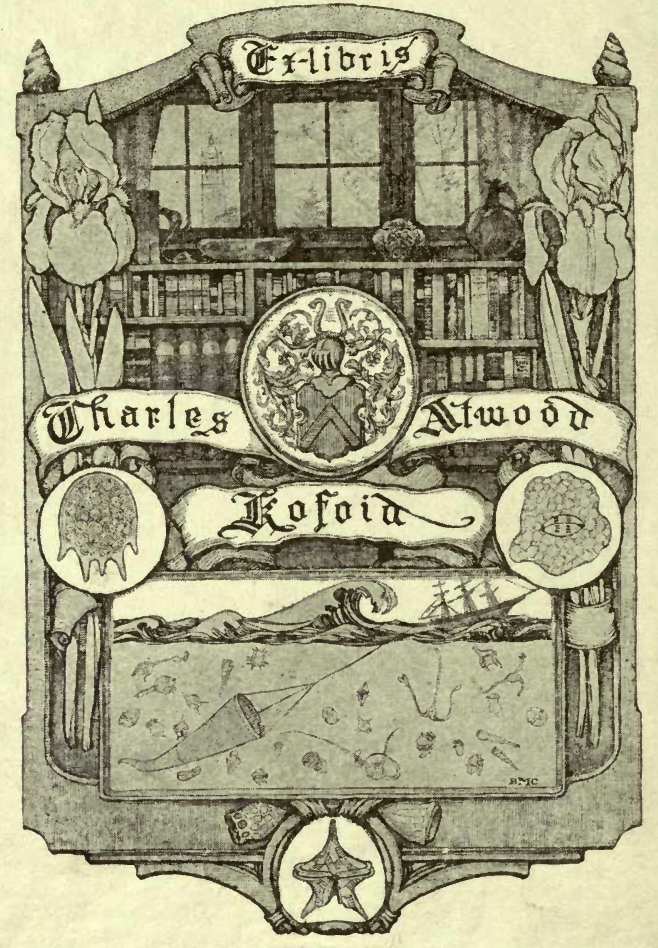


$-45-2-1912 \varepsilon_{1}$ 


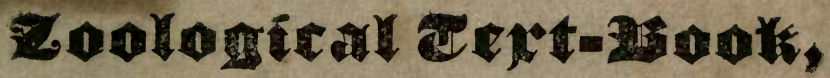

COMPRISING

CUVIER'S FOUR GRAND DIVISIONS

OF

ANIMAES:

-

ALsO,

SHAW'S IMPROVED LINNEAN GENERA,

ARRANGED ACCORDING TO THE

\section{CLASSES AND ORDERS}

OF

\section{UUVIER AND LATREILLE.}

PREPARED FOR RENSSELAER SCHOOL AND THE POPULAR CLASS-ROOH, BY AMOS EATON.

SRORT DESCRIPTIONS OF SOME OF THE MOST COMMON SPECIES IED GIVEN FOR STUDENT'S EXERCISES.

ALBAAY :

PRINTED BY WEBSTERS AND SKINNERS. 
$K-Q L 48$

Biolooy
Library 


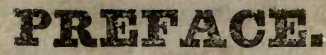

Four years ago I published the grand divis: ions, the classes and orders of Cuvier's Le Regne animal distribue d'apres son organization. Notice was given at the time, that it was my intention to publish a translation of Cuvier's genera. But soon afterwards I was assured that two or three of our best Zoologists contemplated the execution of an elementary system of Zoology. My pupils have now waited for the promised work about two years, since my edition of the classification of Cuvier has been exhausted. I was at last driven to this undertaking; which I entered upon with extreme reluctance. Not on account of love of ease, or that modest diffidence usually complained of by authors. But because it may retard the publication of the promised system of American Zoology, which, it is confidently hoped, some competent naturalist will ere long complete.

In answer to this objection it has been observed by my friends, that such a small book, presenting a familiar outline of the science, might serve as a pioneer for a full system ; as my Manual of Botany did for the enlarged works of Elliott and Torrey. More than four thousand copies of the Mantal, in the hands of botanists, awakened a 
zeal for the science, which rendered enlarged systems desirable and even necessary. So it is conjectured, that a small treatise on Zoology may inspire a degree of zeal, sufficient to encourage the publication of an enlarged work.

It will appear by the title page, that $I$ have adopted Dr. Shaw's genera, instead of Cuvier's ; though I have distributed the genera of Shaw according to Cuvier's system of classification. After comparing Cuvier's system of genera with that of Shaw, I find no other essential difference, than what arises from the numerous subdivisions of the Linnean genera made by Cuvier. The student will consequently learn nothing in using Shaw' genera, which he must unlearn if he should hereafter study animals according to Cuvier' subdivisions. Besides, it is far from being a settled point among naturalists, that the modern subdivisions of genera in the animal and vegetable kingdoms, are preferable to sulddivisions into sections of species according to the method of Linneas, which is followed by Shaw. To these remarks I must add, that Cuvier's long descriptions, which are essential upon his anatomical plan, could not be given in a small school-book. And even if given, they could not be understood in anan cases, without a competent knowledge of anatomy. The species of some of the Linnean genera are subdivided by Cuvier's divisions of 
orders. These cases are few ; and as far as $I$ have applied his orders, I can discover no material inconvenience on this account.

Cuvier's classification is certainly a great improvement upon that of Linneus, in most cases. But $I$ have not followed him in the orders of Pis. ces and of Molluscous animals. His method would undoubtedly be preferable, if we could make it convenient to dissect every animal in these classes, which comes under examination. In the study of molluscous animals, we are chiefly confined to the empty shells; it being impossible for most students to obtain the animals inhabiting the shells. And one important use of the study of Zoology is to prepare the student for geological investigations. In this department we never find the remains, or interior castings, of the soft parts of animals.

Few students will have leisure to pursue the study of Zoology for a great length of time. Therefore they will generally require a text-book, which will lead them by the shortest course to a general outline of the science. And this outline should be pursued by a method, which is adapted to the means of farther progress, which may be within their reach. The only Znglish work, to be found in our towns and villages, to which we can conveniently resort for specific descriptions, is 
Rees' Cyclopoedia. In this extensive work the genera of Cuvier are not adopted. But students will find the zoological genera of that work perfoctly in accordance with this text-book. After: the genus is found here, they may refer to the same genus in Rees by its alphabetical arrangement; where they will find the descriptions of all the species published in that work.

* Zoological articles are very meagre in Rees, before the commencement of the letter, C. The naturalist, Donovon, conducted. most of that article from $\mathbf{C}$, onwards, in a very acceptable manne. 


\section{zOOLOCY.}

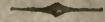

WOOLOGY is the science which treats of material organized beings, which are endowed with the sentient principle.*

It is generally true, that animals differ from regetables in possessing locomotive, as well as sentient, powers. This is a good distinction between the $o x$ and the oak. But is very deficient when applied to the isis and the sensitive plants.

Animals receive their food into an internal cavity or cavities, which is so modified as to furnish the fluids which supply the wants of the system. And probably no substance is received as the food of animals, which has not previously been in an organized state. Whereas vegetables receive inorganic matter for food, as well as that which has been organized; and their food is chiefly received through tubular radicles, or pores of leaves, which have the power to direct their courses or pores towards water, air, light and heat.

All animals have the seuse of feeling. But they have no particular organ for that sensation; it depending on papilla at the ends of nerves which terminate in every part of the skin. All vertebral animals have four organs of sense. Each organ is adapted to its particular office. One for

* "Sentient principle" is not well defined, and no definition of an an. imal bas come to my knowledge which is satistactory. "Organized being" is still wanting in a settled accurate meaning. The student is referred to large treatises on subjects of natural history, for ingenious attempts at definitions and nice distinctions. 
communicating the sensation of sight, one for sound, one for taste, and one for smell. Some of the other divisions of animals have more or less of these organs in greater or less perfection.

All animals seem to require a system of organs for digesting food, for circulating fluids through the body, and for oxydating those fluids. In vertebral animals these organs consist of stomachs, to which an alimentary caunal is attached; a heart. which is alternately compressed and expanded, to which a set of arteries and veins are attachedthe former for conveying the fluids from the heart, and the latter for returning them to the heart; lungs or gills in which the same fluids are presented to the oxygen of the atmosphere. Some animals have their fluids oxydated by means of spiracles, some by means of exterior membranous organs.

\section{SYSTEMATIC ZOOLOGY.}

Animals are distributed into groups, for the convenience of ascertaining their names and of studying their affinities. These groupes or assemblages are called Classes, Orders, Genera, Species and Varieties.

Linneus distributed all animals into six classes. 1. Mammalia, viviparous and suckling the young. 2. Aves, oviparous, having two wings and two feet. 3. Amphibia, lungs adapted to long suspended respiration. 4. Pisces, fins and gills sub. stituted for lungs. 5. Insecta, antennæ in most cases, member's articulated to an external crust. ธ. Vermes, body soft, members not articulated, or wanting.

Cuvier subdivided several of these classes.Mammalia, Aves, Amphibia and Pisces remain as. 
Linneus left them, or nearly so. Insecta is divided into three classes, to which is prefixed a class taken from Vermes. They are Annelida, Crustacea, Arachnida, and Insecta. The remainder of the class Vermes is divided into Mollusca, Echinoderma, Intestina, Acalepha, Polypi and Infusoria. The subdivisions are adopted in this text-book.

\section{GRAND DIVISIONS.}

The subjects of Zoology are distributed INTO FOUR GRAND DIVISIONS ; BECAUSE ANIMALS APPEAR TO HAVE BEEN ORGANIZED UPON FOUR GENERAL PLANS.

\section{RADIATED ANIMALS or ZOOPHYTES.}

In this division the sentient principle is lodged. in, or, in some unknown manner, attached to, a medullary globule, spheroid or ring, with radiat. ing branches.

Animals of this class are but little more complicated in thcir structure than plants. No distinct system of nerves nor any organs of sense, have been discovered. Feint vestiges of circulation are with difficulty perceived. Their respiratory organs are mostly on the surface of the body. Some receive their food through a mouth, others through pores.

Some animals of this division may be cut across, and both parts will live. This is explained by supposing the animal to consist of a column or pile of distinct animals, and that the transverse cutting produces a mere separation of a column of individuals into several shorter columns, 
The process of reproduction among this division of animals resembles that of plants with perfect flowers, Some of them may be propagated by cuttings like plants. In this, and in some other particulars, they seem to partake of the nature of plants and animals; and are therefore called zoophytes, or animal-plants. They are the most simple in their organization, and seem to have been some of the earliest inhabitants of the earth; as some of the species are found in the oldest rocks, which contain any petrifactions.

Example. Sea-hedghog, starfish, sea-nettle, corals, corallines, animalculæ, tape-worm.

\section{MOLLUSCOUS ANIMALS.}

In this division the sentient principle is lodged in a number of medullary masses, dispersed in different parts of a soft body. And though the medullary masses are not always united by nervous filaments, the organs of sense and motion are arranged more or less on two sides of a nervous axis or longitudinal series of medullary masses.

The principal medullary mass is situated upon the throat. The circulatory system is considerably complicated; much more so than that of the articulated division. The blood is dark coloured or blue. Fibrin appears more abundant than in vertebral aninsals. Their muscles are attached to many parts of the skin, forming a tissue more or less complicated and compact. By various contractions and elongations they move, swim, and perform other motions. They have considerable irratibility; the naked skin is very 
sensible and furnished with a liquid humor which issues from its pores.

Molluscous animals are generally cóvered with plates of carbonate of lime, which serve as beds or retreats from danger. These plates, usually called shells, are produced by secretion from the skin. The process of reproduction greatly re. sembles that of plants with perfect flowers ; rareiy that of diocious flowers.

Animals of this division, though more compli. cated in their digestive and circulatory system than animals of the articulated division, * seem to have been cotemporaries with the oldest of the radiated division. For we find the remains of several species of this division in the oldest transition rocks, which rarely if ever, contain any relics of the articulated or vertebral divisions.

Examples. Nautilus, snails, oysters, barni. eles.

\section{ARTICULATED ANIMALS.}

In this division the sentient principle is lodged in two long cords, swelling at intervals into knots or ganglyous, extending through a jointed body in the longitudinal direction. The organs of sense and motion are all double, and arranged on two sides of the nervous axis.

The principal ganglyon is placed near the throat. They have jointed trunks or abdomens; and all but one class, have jointed limbs articula-

* Cuvier places this division between the vertebral and articulated, on account of the greater perfection of the residence of the sentient principle. For if the bee is more active than the oyster, so the cat and pigeon are more active than man. But we have changed the order to accommodate it to the study of petrifactions and shells; for very few have the means for studying the anatomical structure of mollus ceous animals. 
ted to an external crust or to a rigid covering They draw in their food through suckers or tubes serving as mouths, in most cases. Air vessels, through which respiration is performed, open on the sides of their bodies or limbs.

They have two eyes, which may be of two kinds. The simple kind appears like a small lens. The compound kind has its surface divided into an infinite number of lenses; each answering to a fibre of the optic nerves. Excepting the classes of jointed worms and of spiders, all ar ticulated animals have antennæ ; being jointed, fie liform, flexible horns. With these they seem to effect many purposes; such as examining bodies within their reach, determining the state of the atmosphere, and to derive sensations of which we have no knowledge.

They have the sense of smell and of hearing; but it is not known in what organs these senses are placed. Some have jaws of a curious character. Often a pair of strong pincers for grasping and breaking up their food, and for defence. These are called mandibles. Two pairs within these are called levers and lips. To the levers or jaws are attached jointed filaments, called palpi or feelers, which are supposed to serve the animal for examining its food. The tongue commonly adheres to the lower lever. In some the fore feet serve in place of some of these appendages; in others the jaws are increased in number. Some have a proboscis or tube through which food is imbibed.

They are mostly produced froin eggss. Some become perfect immediately from the egg; but more are changed from the egg to the larva, (called caterpillar, worm, maggot or skipper) from 
larva to crysalis, from crysalis to the perfect insect. They are generally the most voracious while in the larva state. Some live long in the larva state, and but a short time in the state of the perfect insect. As the cicadia septendecim (American locust,) remains in the larva state sevcnteen years, and in the state of perfect insect but about a week, and eats nothing during that period. Others are in the larva state but a short time in proportion to their duration in the insect state ; as musca domestica, the common house-fly, which continues a long time and eats continually.

Animals of this division were probably created before the vertehral. For it is said that the castoff crusts of the crysalis of some species are found in older rocks than the bones of vertebral animals. I have never found any such relics. Perhaps fish are found in formations about as old as any of this division.

Examples. Angle-worn, leach, lobster, spider, beetle, cricket, bee, butterfly, gnat.

\section{VER'TEBRAL ANIMALS.}

In this division the sentient principle is lodged in a medullary substance, the basis of which is inclosed in a bony tube, composed of a column of vertebra.

To the nervous axis enclosed in a bony tube, which is called the medulla spinalis, there is an appendage at one extremity, denominated the brain. This is inclosed in a bony case, called the cranium. But animals of this division have another system of nerves, more analagous to the systems found in the other three divisions, than the 
medulla spinalis. It is that system which extends through the heart, lungs, and stomach, and is cunnected with the brain by a very ininute fibre.Nature seems to have been very solicitous to provide for the digestive, respiratory and circulatory systems, in every division of animals. The system of nerves, devoted to this object, is kept almost distinct in vertebral animals, and the medulIa spinalis, as well as the brain, seem to be but appendages.

The organs of sense and motion are all double, and are arranged on two sides of the nervous axis. To the vertebral column are attached two series of ribs, constituting the chief frame-work of the body. Strong bony limbs are bound to each extremity of the bony column, which are mostly covered by the muscles which give them motion. All the proper visera are inclosed in the head and trunk.

Both brain and medulla spinalis being peculiar to this division, the sentient principle is much more perfect in this than in the other divisions. Here we find four pair of organs of sense. Two eyes, two ears, two nostrils, and two fleshy masses constituting a tongue, or rather a pair of or. gans of taste.

These animals have red blood, hearts with alternate sistole and diastole motions, horizontal jaws adapted to the preparation of food for the digestive process. They are viviparous or oviparous, and from the commencement of their lives till death, they supply the daily waste of their bodies by masticating and passing into the stomach, aliment suited to their respective natures. A 
part of this aliment is carried into the circulatory system by lymphatic vessels.

Animals of this division being more complicated in their structure, are subject to a greater variety of diseases. They have more acute pains and more exquisite pleasures.

Examples. Man, bat, squirrel, elephant, deer, whale, eagle, humming-bird, tortoise, crocodile, viper, frog, eel, shark, salmon. 


\section{SENTIENT PRINCIPLE,}

ACCORDING TO TIE ORDER OF THE FOUR GRANB DIVISIONS OF ANIMALS.

\section{RADIATED ANIMALS.}

The sentient principle in this division of animals, is scarcely manifest. Many of them being fixed like a plant, and scarcely exhibiting any signs of irritability, are hardly distinguished from plants, or even from minerals. If they are sensible to pleasure or to pain, few of them have the means of making their sensations known to man.

\section{MOLLUSCOUS ANIMALS.}

The nervous and circulatory systems being more complicated, we infer, from analogy, that this division of animals possesses the sentient principle in greater perfection. But such is their clumsy structure, that they are incapable of evincing their superiority to the radiated divisions, if they are really superior. Some species of snail have considerable locomotive power ; and exhibit signs of fear, and retreat suddenly from danger. Some species of the bivalves change situation as their wants seem to dictate. Little, however, can be said of the sagacity of this division of animals.

\section{ARTICULATED ANIMALS.}

Though the nervous and circulatory systems are less perfect in this than in the last division of animals, their forms being better adapted to the exbibition of their pleasures, pains, and wants, they 
appear to be the more perfect. It requires the imagination to be severely disciplined by the controul of the reasoning powers, and the authority of analogy, to yield to the opinion, that the clumsy inert shapeless oyster is more intelligent than the frugal bee, the provident ant, and the revengeful wasp.

Among this division of animals, we discover instincts, which guide their actions like the wisdom. of sages. But as they have no brain, we cannot ascribe to them any of those faculties of mind, which seem to be lodged no where but in that organ.

\section{VERTEBRAL ANIMALS.}

Animals of this division are furnished with the appendage, at the anterios extremity of the medulla spinalis, denominated the brain. This appendage consists of fibrous fascicles, radiating in pairs from the end of the medulla spinalis, and terminating at the inner surface of the cranium, and inveloped in a soft ash-colored medullary substance. These fascicles are few in number in the class of fish, more in the class of amphibious animals, more still in birds, and most of all in the class mammalia, or in that class in which the young are nourished with the milk of the dam. Experience teaches us, that the sagacity of animals increases as we ascend the scale of increased fascicles.The lizard and suake are more sagacious than fish; the bird more sagacious than lizards and snakes; the $\operatorname{dog}$ and horse more sagacious than birds.

In ascending the scale of orders in the class mammalia, we find the increased number of cere. 
bral fascicles indicating higher degrees of sagacity, until we arrive at the order bimanes, in which man alone is found. Man has a different set of cerebral fascicles from any other animal. These fascicles terminate in that part of the head called the forehead, which, in most heads agrees in its boundary lines with the limits of that part of the head which is covered with hair. Many of the fascicles terminating in that part of the human head which is covered with hair, man has in common. with some other animals ; but those of the forehead are peculiar to man.

Residence of the mental faculties of man, OR PHRENOLOGY.

It is the opinion of some philosophers, that the faculties of the mind are distinct and located; also, that their particular locations may be ascertained by a long course of careful observations. The facts collected by such a course of observations, have been arranged iu systematic order; and the authors of this arrangement have denominated it the seience of phrenology. Many consider this pretended science as mere quackery, unworthy of any serious attention. Others have. treated it as a science, deserving particular attention. It was scarcely noticed by men of science in Europe or in America, excepting for purposes of burlesque and ridicule, until the opinion of the professors of the French National Institute appeared in the printed journals. Though the systen of Gall and Spurzheim was not admitted as a science, the serious manner in which it was treated by a constellation of the greatest men of this age, and their decided approbation in relation 
to some important facts, discovered in the anatomy of the brain, induced many learned men of both continents, to give the sulject a serious discussion The approbation of Sir Astley Cooper, also induced much isquiry. Whatever may be its fate, whether it is destined to die with its authors, or to be received as a science, it seems necessary at the present day, to understand the general outlines of its principles. We shall, therefore, give a few pages to the subject; merely sufficient to acquaint the stadent with its principles, without giving a detailed exposition of the anthors' arguments or applications.

The mind is supposed to be a substance totally distinct from matter, and to take its residence in the brain for a season. in a manner somewhat analagons to the residence of the electric fluid in the tinfoil which lines a Leyden vial. As the electric fluid may lie dormant here, or may be in a situation to exert its powers, without destroying it or changing its uature, so the mind may reside in the brain in a torpich or in an active state, without any essential change. As the electric fluid may at one time reside in tinfoil, again in vapor, and again in the earth, witbout any change or without partaking of the nature of the tinfoil, of the vapor, or of the earth ; so the mind or soul may at one time reside in the brain, at another in the regions beyond the grave, without any change or without partaking of the nature of the brain, \&c. And as the electric fluid will exert its powers, while in connexion with the tinfoil, \&c. to better or worse advantage, as it is more or less favorably situated, though its essential qualities willnot be altered, so the mind will exert its powersto bet- 
ter or worse advantage, while in connexion witls the brain, as it is more or less favorably situated, though its essential qualities will not be altered.

In order to ascertain on what circumstances the favorable operations of the powers of the mind depend, an extensive series of comparisons was necessary. One point was soon ascertained. The united observations of mankind for ages, has demonstrated, that all persons whose foreheads are greatly compressed are idiots, though in the best state of health. Hence a safe inference was drawn, that the developement of a duly proportioned volume of brain in the forehead, is essential to the advantageous exercise of the powers of the mind. After proving that a due developement of volume was necessary to common sense, enlarged and compressed portions of the brain were to be examined, in cases of remarkable strength or weakness in any of the faculties of the mind. If one individual possessed remarkable discriminating powers, and another was strongly predisposed to be at variance with others; and if the former had a remarkable prominent ridge in the centre of the upper part of his forehead, and the latter had an unusual prominence back of his ears, the prominent ridge in the forehead would be called the organ of discrimination, and the prominence back of the ears, the organ of combativeness. Should the same coincidence of prominences and faculties frequently occur, after twenty or thirty years of accurate observation, the location of them would be considered as the residence of such faculties; and their volume would indicate their degree of strength or weakuess. 
Upon such a course of observations, Gall and Spurzheim have constructed their system. And now they call upon the scientific world to apply their rules to all the cases which occur to each observer, in order to test their system. The following is a description of their rules in substance.We have omitted their minute subdivisions, which seem to have been the result of that excessive zeal which men often feel for a favorite theory.

\section{PHRENOLOGICAL FACULTIES.}

Order I.

The Feeling Faculties. These are located in that part of the cranium which is usually covored with hair. Some of these are found in other. animals.

\section{Order II.}

The Intellectual Faculties. These are located in that part of the cranium, which is usually destitute of a hairy covering. None of these. are found in any animals but men.

Men are said to be more strongly predisposed to be controuled by their feelings, or by their intellectual faculties, as the volumes of those twe parts of the head bear relation to each other, measuring from the passage into the ear.

\section{Genera.}

The first order is divided into

Genus 1. Propensities. This genus of faculties includes the lower part of the order. Com- 
mencing with the cerebellum, it extends forward of the ears to the boundary line of the second order.

Genus 2. Sentiments. This genus of faculties includes the upper part of the order. Commencing above the greatest prominence in the back part of the head, it extends forward to the boundary of the second order.

The second order is divided into

Genus 3. Knowing faculties. This genus of faculties includes the lower part of the order.

Genus 4. Reflecting faculties. This genus of faculties includes the upper part of the order.

N. B. In well propurtioned heads, the line of division between the first and second genera, in both orders, runs parallel to the base of the cranium, about equidistant between the top and bottom of it.

\section{Sections.}

\section{Genus 1.}

Section 1. Retiring benignity. Those facullies which dispose to love, friendship and retirement, also enable the possessor to concentrate his thoughts in the investigation of abstruse subjects.

Location. In the back part of this genus; being the part of the head near the top of the neck, and extending above the most prominent part of it.

Section 2 Invinsible self-love. Those faculties which dispose to effect our own purposes, whether controversies, secrecy, strong offensive and defensive measures, private defensive build. ings, or whatever other mcans may be required for it. 
Location. The forepart of this genus, being near the ears.

\section{Genus 2.}

Section 3. Approving justice and firmness.Those faculties which dispose to cautiousness, justice and firmness, with a consciousness of merit and a desire for approbation.

Location. The back part of this genus, being in well proportioned heads, the highest part, and extending downwards below the lateral prominences.

Section 4. Benevolent enthusiasm. Those aculties which dispose to benevolence and an enthusiastic devotedness to the happiness of others and to divine worship. It often leads to poetic reveries and fantastic hopes.

Location. The fore part of this genus beginning above the naked part of the forehead, running about half way towards the crown, and extending half way down towards the ears.

\section{Genus 3.}

Section 5. Elegant poucers. Those faculties which are adapted to music, painting, ready reckoning and eloquence.

Locality. That part of this genus which would be included under a narrow belt, crossing the eyes and extending up from the outer half of the eyes, about half way to the top of the forehead. The enlargement of the fascicles back of the eyes, is indicated by prominent eyes. In these fascicles the faculty of eloquence in particular is supposed to reside. 
Section 6. Inventive powers. Those faculties which are adapted to the invention and execution of original plans, whether they relate to forms of machinery, arranging the course of business in which one is engaged, constructing scientific systems, or whatever else requires a talent for suggesting original forms and schemes.

Location. That part of this genus which is situated at the bottom of the centre of the forehead, at the origin of the nose. The breadth of the nose at its origin and the projection of the forehead at that point, indicate the strength of the faculties of this section.

Section 7. Ready perception. Those faculties which are adapted to the ready acquisition of a superficial knowledge of objects, such as to know a human countenance after a single glance, to be able to ennumerate the individual parts of an extensive pleasure ground, of an artificial work, or of a long story or song, without study or fatigue.

Location. The centre of the lower part of the forehead, from above the origin of the nose to half the height of the forehead.

\section{Genus 4.}

Section 8. Philosophic powers. Those faculties which are adapted to the tracing of cause and effect, to making accurate distinctions, to solving mathematical problems, and to judging in all other cases where the subject is so presented to the mind as to be understood.

Location. That part of this genus which occupies the upper and middle part of the forehead, and extends about half way to the origin of the nose. 
Section 9. Comic powers. Those faculties which are adapted to the perception and performeance of mimicries, and to comic and witty sayings.

Location. The upper corners of the forehead, and extending down the outer limits of it half way to the eyes.*

\section{Remarks.}

In estimating the nine sections of the head, general dimensions should be considered in most cases ; and no head can be a fit subject for examination which has been enlarged or distorted by disease. Sections 1, 3, 4, 6 and 8 , should be estimated by considering the dimensions of the brain from the passage into the ear. Section 2, should be estimated by the diameter of the head immediately above the ears. Sections 5, 7 and 9, should be estimated by comparing their prominent or compressed state with the arljoining sections.

It is supposed that a well proportioned head indicates intellectual strength, but want of mental activity. And that a head whose sections are greatly disproportioned to each other, indicates great activity in the prominent locations. These two rules are said to be founded on many obser-

* Gall and Spurzheim have weakened their system by descending to 33 minute subdivisions. Section 1 , is divided into amativeness, philoprogenitiveness, inhabitiveness and adhesiveness. Sec. 2, combativeness, destructivencss, constructiveness, covetiveness and secretiveness. Sec. 3, cautiousness, conscienciousness, firmness, love of approbation, self-esteem. Sec. 4, benevolence, veneration, hope, ideality. Sec. 5, individuality, lecality. Sec. 6, form, size, weight, momenta. Sec. 7, colouring, order, time, number, tune, language. Sec. 8, conparison, causality. Sec.9, wit, imitation.

Those who wish to study the faculties, as here enumerated, are referred to Dr. Bell's edition of Combe's elements of Phrenology. - Dr. Caldwell, of Transylvania University, has published a work on this subject, which is said to possess great merit; but I have not been able to obtain a copy of it. 
vations. It is explained on the principle, that when all the sections are in equilibrio, the faculties correct and moderate each other; while an unbalanced faculty acts vehemently without restraint.

A weak faculty may be strengthened by exercise, and a strong one may be weakened by neglect. An amiable child may be made quarrelsome and wicked by experiencing perpetual cruelties. His faculty of combativeness is thus strengthened by use; while his faculty of benevolence becomes enfeebled for want of objects to excite it into healthy action. On the same principle evil propensities may be put down and the best sentiments strengthened by careful and discreet culture.The great diversity in the mental faculties of human individuals is ascribed to the state of society and individual elucation through many generations. Very little diversity is observed among wild animals ; while individuals of the same species of domesticated animals present heads very different in form.

The advocates for this system of phreuology suppose that it furnishes a ready solution of many operations of the mind. Insanity (which often seems to affect but one faculty of the mind, while all the others remain unimpaired) they say may be explained by supposing that pair of fascicles, in which the disordered faculty is lodged, to be so far impaired as to embarrass that faculty in the exertion of its powers. 


\section{( 27$)$ \\ PIIMITITARY PRRIMS}

EMPLOYED IN ZOOLOGY.

The science of animals was divided by Linneus into six branches, each according with one of his six classes. The French have prefixed a more general two-fold division. These divisions, however, are rather popular than scientific.

Animals are divided into

VER'TEBRAL, having back-bones.

AVERTEBRAL, destitute of back-bones.

VER'TEBRAL animals are divided into

1. QUADRUPEDS, the science of which has no popular name. It includes four fonted animals; as ox, dog, mouse.

2. Birds, the science of which is called ornithology. It includes the featherel tribe ; as pigeon, goose, wren.

3. Aмpнiвious animats, the science of which is called amphibiology. It includes those cold-blooded animals, which are capable of living on dry land or in the water; as tortoise, lizard, serpent, frog.

4. FIsH, the science of which is called ichthyology. It includes all aquatic animals, which have gills and fins; as shad, trout, sturgeon, eel.

\section{AVER'TEBRAL animals are divided into}

5. INsECTs, the science of which is called entomology It includes all animals with jointed bodies, which have jointed limbs ; as flies, spiders, lobsters.

6. VERMES, the science of which is called helminthology. It includes all soft animals of the avertebral division, which have no jointed limbs, with or without hard coverings; as angle-worms, snails, oysters, polypi, infusory animals. 
Renarks. These popular divisions are inserted for the purpose of giving the mind of the student the right direction, in regard to the language to which he has been accustomed. For the same purpose, he should be guarded against considering layva as entitled to a place among vermes. Though larva are usually ralled worms, they are insects on the Uransmigratory passage from the cgg to the winged state. Therefore the student is to consider the caterpillar, the maggot, the web-making larva, and all other common animals called worms, excepting the angle-worm, as insects.

\section{ELEMEN'TARY PARTS OF ANIMALS.}

In describing animals, their bodies are divided into ten parts. 1. Head, 2. Neck, 3. Thorax, 4. Abdomen, 5. Fore-legs, 6. Hind-legs, 7. Fore-feet, 8. Hind-feet, 9. Toes, 10. Tail. Four common appendages are included, as elementary parts. 1. Horns, 2. Noses, 3. Smellers, 4. Corering. These parts are not found as constituents or appendages of all animals; but all animals are made up of more or less of them, or of what are analagous to them.

\section{ANAIAGOUS PARTS OF ANIMAIS.}

1. Mammalia, heat-Aves, head-Amphibia, head-Pisces, head-Insects, head-Vermes, fore end.

Q. Mam. neek-Ar. neck-Am. neck-Pi. none-In. neck or none-Ver. none.

S. Mam. thorax-Av. thorax-Am. thorax-Pi. thorax -In. thorax-Ver. nothing.

4. Mam. abdomen-Av, abdomen-Am. abdomen-Pi. abdomen-In. abiomen-Ver. abdomen.

5. Mam. fore legs-Av. wings-Am. lore legs-Pi, nothing - In. wings or nothing-Ver. nothing. 
6. Mam. hind legs-Av. legs-Am. hind legs-Pi. nothing-In. legs-Ver. fleshy processes or nothing.

7. Mam. fore feet-Av. quill-feathers-Am. fore feetPi. pectoral fins-In. nothing-Ver. nothing.

8. Mam. hind feet-Av. feet-Am. hind feet-Pi. caudal fins-In. tarsi-Ver. nothing.

9. Mam. toes-Av. toes-Am. toes-Pi. rays-In. hooks -Ver. nothing.

10. Mam. tail-Av. rump and feathers-Am. tail or nothing-Pi. tail-In. tail or nothing-Ver. tail or nothing.

\section{Arpendanes.}

11. Mam. horns or nothing-Av. caruncle, crown or nothing-Am. spines or nothing-Pi. spines or nothing-In. antenna-Ver. nothing.

12. Mam. probosis or nose-Av. beak-Am. nose-Pi. nose-In. proboscis or mandibles-Ver. nothing.

13. Mam. smellers or nothing-Av. nothing-Am. nothing-Pi. tentaculæ or nothing-In. palpi-Ver. tentaculæ.

14. Mam. hair-Av. feathers-Ain. crust, shell or nothing-Pi. scales-In. crust, scales or nothing-Ver. shell, stoney tube or nothing.

\section{RELATING TO THE HEAD.}

OccrpitaI, pertaining to the back part of the head. Lores, the naked lines on a bird's head between the eyes and the base of the bill.

Auricles, ear-like feathers.

Mandibles, the upper and lower jaws of a bird's beak or bill.

Cere, membrane covering the base of a bird's bill.

Frovtuet, the part back of the base of a bird's bill, generally bristly. 
Cultrate, a beak resembling a pruning-knife or coulter.

WatTLES, fleshy appendages under the chin.

Missme-tongue, which may be thrust far out of the mouth.

Nictitant-Membrane, a semi-transparent eye-lid.

ExSERT, teeth, \&c. projecting out.

Incrsors, front, or cutting teeth.

Cuspidates, canine teeth, next to Incisor's.

MoLAREs, grinders, the teeth farthest back in the month. VIBrissae, smellers, hair of the nostrils.

Protrusine, when the heal may be thrust out. Retractue, when the head may be drawn in. Erfuse, with a pouring outlet, like a pitcher nose in the mouth of some shells, as cyprea.

Byssus, silky fibres at the hinge or head of some shells. BEARD, tendril-form appendage to mouths of fish.

Grut-covers, the bony or cartilagenous substance placed on the gill-membrane.

GiLl-Membrane, the meinbrane covering the gills. Bronchiat, pertaining to the gills. Stramiata, small lucid globules resembling eyes, on the top of the head; generally three in number.

\section{RELATING TO THE NECK.}

SCRAG, back of a bird's neck.

InDistinct, when the head and breast grow in one piece.

III. RELATING TO THE THORAX OR BREAST. Ventricles, the larger cavities of the heart. Auricles, the smaller cavities, above the larger, and resembling ears in appearance. 
LATERAL-IINe, the side-line of many fish, dividing the back from the belly.

Dorsat, relating to the back.

Dorsal Fins, any back-fiu between the head and tail-fin. Pectoral- fins, a pair girowing on each side the breat. Porsers or Hatícers, globules on slender stems under the wings of some two-winged insects. Scutel, or Escutcheor, a piece between the bases of the upper wings, un the backs of insects. Hyaline Scutel, \&c. glass-like.

IV. RELATING TO THE ABDOMEN OR BELLY.

Nayant, fluating in water.

Turbinatre, shaped like a top.

Phosphorescent, emitting light in the dark.

Aboominal, relating to the belly.

ABDominaL-RINGS, annulas, or ring-form segments of the belly of insects ; generally 5 .

Cloaca, a general vent, where eggs, urine and foeces are evacuated.

VENT, the aperture in fish where foces, \&c. are discharged.

ANaL-Fins, one or more between the vent and caudal fins.

Abdominal-rins, any where under the fish, between the head and rent.

V. RELATING TO FORE-LEGS AND WINGS: AULULET, (spurious wing, a tuft of 3 or 5 feathers on the outer fore-joint of a bird's wing.

Tecrrics, (wing-coverts, the longest feathers in a wing, next above the quills.

Minor-Tectrics, (lesser wing-coverts, the wing-feathers above the tectrics. 
Articulated, united by a joint.

Euxtra, the upper sbelly wings of insects.

Truncate, appearing as if abruptly cut off at the end. RETuse, ending in an obtuse sinus, or rounded notch. Dersex, wings bent down arch-wise.

Uceliate, eye-form spots.

\section{RELATING TO THE HIND LEGS.}

LEGs of insects are always 6 or more; and are divided into thigh, shank and tar'sus.

Fettered Legs, partly involved in the intigunem of the abdomen, or bent back, so as to be unfit for walking with facility.

VII. RELATING TO FORE-FEET, \&c.

Primary Remiges. (quill-feathers, the outer and lapgest quills of the wings.

Secondary Remiges, smaller quills, adjoining the primaries.

Tertals, inner smallest quills, adjoining the secondaries.

Pectoral-rins, on each side of the breast, behind the gills.

RAYs, the fibres or bony spines of fins and gill membranes.

VIII. RELATING TO THE HIND-FEET.

Natant, feet and appendages formed for swiming.

Gressorax, feet formed for running or walking, with three toes forward and one back; the two outer toes mostly jointed haif way.

Scansoniax, feet formed for climbing ; two toes forward and two back.

Perching, grasping, hawk-like.

Chemate Claws, forcipated foremost feet in some insects, as lobster. 
TArsus, * the ancle or foot of an insect, generally long and many-jointed.

Caudat-fins, on the end of fishes tails.

\section{RELATING TO THE TAIL.}

Premensule, formed for coiling around, and holding by, substances.

RUMP, the cordate process supporting the tail of a bird. Tam-Feathers, the large feathers of the tail, generally 12 , sometimes $10,18,20,24$.

Expansiue, capable of being spread.

Tait-coverts, the clump of feathers next above the rump.

UropygraI, (or hypochondriac,) several long feathers above on each side the tail, differing in form from the others.

\section{RELATING TO THE HORNS, ANTEN-}

N $\mathrm{EE}$, \&c.

ANTENN Es, the horns or jointed processes on the heads of insects, generally forward of the eyes. They are short, when not so long as the body; long, when longer ; moderate, when about equal.

Setaceous Antennas, shaped like a bristle, tapering from base to point.

Fusiform, spindle-form, being largest near the middlo and tapering both ways.

LAMINATED, consisting of several thin flat portions.

Fmiform, thread-form, of nearly equal size through its whole length.

Clavate, club-form, thickening at the end, sometimes ending in a knob.

* In numbering the joints, the last cylindrie one is reckoned, leaving nothing out of the number but minute claws at the very tip. 
Perforiate, knobs or joints flattened into circular plates, so that the antenna seems to pass through their centre.

Moniliform, joints more or less globular, so that the whole in some manner resembles a string of beads. -Serrate, joints so formed that the sides of the antennæe resemble saw-teeth.

Pectivate, comb-form, numerous fine processes along one or both sides, pointing somewhat towards the tip. Barbate, processes pointing backward.

Fissice, split at the tip into several flat separations.

Prismatic, having two or more flat sides.

Drffracted, twice bent; first outwardly, then forward, as in ants.

Caruncle, fleshy protuberance on the heads of some birds, as turkies.

XI. RELATING TO PROBOSCES, NOSES, TENTACULA, \&c.

Proboscrs, elongated tubular snout or sucker.

Tentacula, the arms, or feelers, of insects and vermes. Palpi, the feelers attached to mouths of insects.

Lenticular, resembling small lentils which are somewhat the form of the convex glasses in spectacles.

XII. RELATING TO HAIR, FEATHERS, \&c.

Cineraous, greyish, colour of ashes.

Scapulars, feather's descending down each side of the back.

INTERSCAPULARs, the back-feathers, between the bases of the wings.

Marlen, covered with a kind of long hard armor. Cataphracted, callous skin, ol cartilagenous scales. 
Muricate, clothed with sharp rigid points.

Echinate, covered with prickles, as hedge-hog.

Torose, knobbed, like a toad.

Paprlaose, covered with fleshy pimples.

Lacunose, covered with small pits.

Pruinose, covered with frost-like meal.

Pelifcid, clear, transparent.

\section{RELATING TO REPRODUCTION.}

VIVIPaRous, bringing forth young without eggs, being first produced alive.

Oviparous, young from eggrs.

STOLoniferous, produced by cions or shoots.

Ovum, the egg as first produced from the animal. LARVA, animal in the caterpillar or maggot state.

Pupa, (aurelia, nymph, chrysolis,) quiescent state of an insect after passing from the larva.

Ima Go, the perfect, full-formed insect. 
$x^{3}$

Sis.

6

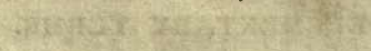

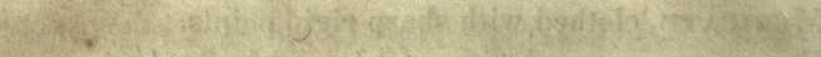

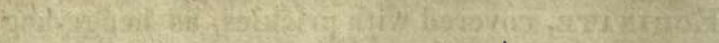

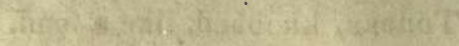

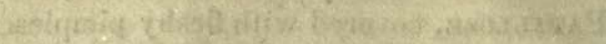

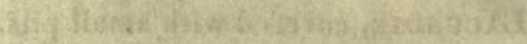

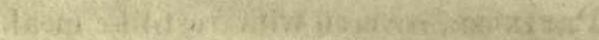

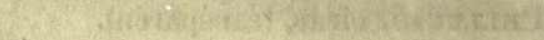
WowT-gen

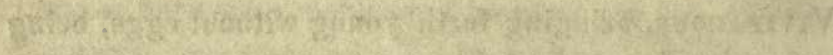

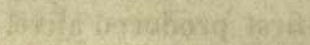

-

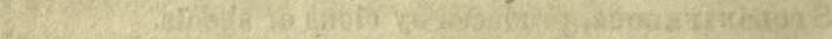

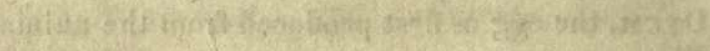

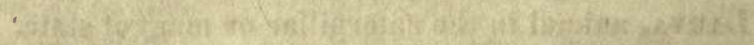

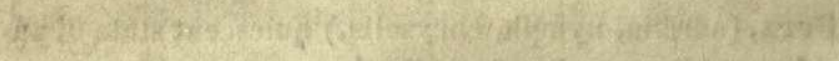

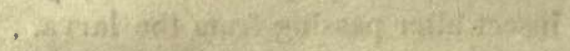

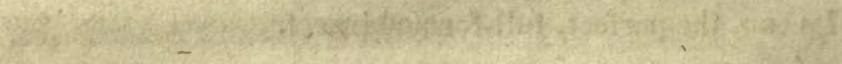
32

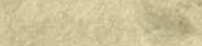
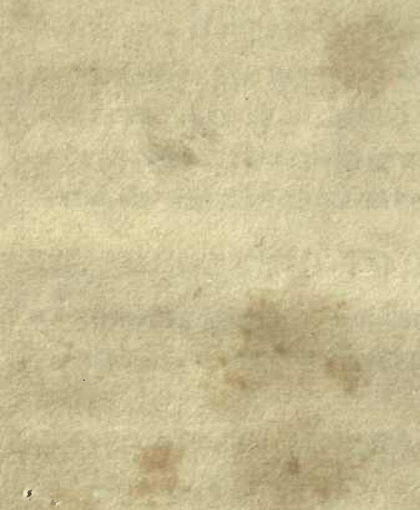

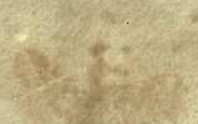




\section{$(87)$ \\ CLASSIFICATION OF ANIMALS.}

Having considered the animal kinglom with peference to the succession of animals in the order of creation, and the sentient principle; we now commence with a system of classification, udapted to the analysis of animals, for the purpose of ascertaining generic and specific names.

The vertebiral animals are distributeb INTO FOUR CLASSES.

1. Mammalia, viviparous and the young nour. ished by the milk of the dam.

Heart with two ventricles and two auricles.Lungs respire alternately.

Examples. Man, ape, bear, beaver, sloth, horse, ox, whale.

2. Aves, oviparous, having two wings and two feet.

Heart with two ventricles and two auricles, covering imbricate feathers. Lungs ventilated by alternate contractions and expansions of air cells below them ; not by their own motion. Jaws, or mandibles, naked and without teeth. Ears without auricles.

Examples. Hawk, swallow, parrot, hen, crane, goose.

3. Aмpнiвis, capable of suspending respiration a long time, without impeding the circulation of the blood.* Oviparous or viviparous, without fins.

Heart with one ventricle. Cold-blooded, covered with strong scales or with a naked skin.

* Cuvier and several other zoologists substitute reptilia for amphibia. Cuvier's own definition is founded on the amphibious nature of this class; while the lizard and frog are not reptilious. 
Examples. Tortoise, lizard, snake, frog, sal. amander, proteus, siren.

4. Pisces, oviparous, having fins, and no feet.

Heart with one ventricle, blood cold, gills substituted for lungs, covering imbricate scales.

Examples. Sturgeon, sunfish, pipefish, shad, bullhead.

\section{ARTICULATED ANIMALS}

ARE DIVIDED INTO FOUR CLASSES.

5. Annelida, without a bony skeleton and having red blood Body soft, elongated; covering divided into numerous transverse rings.

Mostly living in water. Some of them secrete calcareous matter, which forms a stony, tubular covering.

Examples. Earth-worm (angle-worm) seapipe, leech, hair-snake.

6. Crustaced, animals with jointed limbs, which are articulated to a hard calcareous crust. They respire by a kind of gills.

Their gills are pyramidal, marle up of plates, or bristly with threads, plumes or simple plates. They generally occupy the base of the feet. They have mostly four antennæ, ten feet and six jaws: one under lip is always wanting.

Example. Lobsters, crabs, horse-hoofs.

7. Arachinda, animals with jointed limbs, without antenne. They respire by little openings at or near the termination of the thorax, which lead to organs resembling lings; or by little trachea or pipes distributed over the whole body.

The head and thorax are blended together. They have mostly six or eight eyes, and eight 
feet. They feed chiefly upon living animals. They do not pass through any material change after they are produced, as insects do.

Examples. Spider, grey-beard.

8. Insecta, animals with jointed limbs, and antena. They respire by two principal trachea or pipes ruming parallel to each other through the whole body: which throw off at intervals many branches to the surface of the body, through which air is admitted.

The head and thorax are distinct, antenna two. They are mostly winged, having; one or two pair; a few are without wings. They have six feet, excepting that some of the wingless genera have znore : their mouths consist of six pieces, disposed in pairs, but do not all move in the sa me direction. One pair is sometimes called the mouth or mandibles, another the lips, another is a kind of cloven tongue. In some insects the mandibles become a kind of beak. Most insects pass through several states of transmigration. 1. 'The egg, 2. the larva, 3. the chrysalis, 4 . the perfect insect.

Example. Thousand-leg, flea, grasshopper, butterfiy, miller, house-fly.

\section{MOLLUSCOUS ANIMALS}

ARE INCLUDFD IN ONE* CLASS.

9. Mollusca, bodies soft without internal skele. ton, external crust or jointed limbs. Covering, a soft skin without rings; sometimes defended by stony plates.

Blood white or bluish. Their muscles being attached to the skin without any solid supporters;

* Cuvier divides them into six classes. But it appears to be more convenient to make orders of such obscure classes. 
their motions consist in various curviliuear contractions, contortions and elougations.

Examples. Snail, slug, oyster, clam.

\section{RADIATED ANIMALS}

ARE DIVIDEB INTO FIVE CLASSES.

10. Echinonerma, spine covered animals. They have intestinal organs of respiration and for a partial circulation.

Their organized structure is more complicated than that of any other class of this division.

Examples. Sea-star or star fish, sea-hedgehog.

11. Intestina, animals inhabiting the bodies of other animals. They have no discoverable organs for respiration or for circulation.

They are generally oval, long, terete or compressed ; with their orgaus longitudinally arranged. Some have an intestinal canal, others have none. They generally inhabit the intestines,* glands, or cellular integuments of other animals.

Examples. Tape-worm, hydatids.

12. Acalepha, circular radiated animals, without organs of respiration or circulation.

They are the largest of the Zophytes. They differ from the class Polypi by the developement of the tissue of their organs.

Examples. Sea-anemone, zoanthus, kraken?

13. Poly PI, small gelatinous animals with mouths surrounded by tentacula. The conducting tube, passing into the stomach, simple or passing down in the form of vessels.

* Cuvier says, the most efficacions vermifuge is animal oil mixed with oil of turpentine. 
This class embraces that numerous tribe of compound animals which inhabit or rather compose, fixed stems, often called marine plants.

Examples. Corals, sponges, sea-fans.

14. Infusoria, animals which abound in stagnant liquids only; and which cannot be discovered without the microscope.

Most of these animals are gelatinous without any organized viscera. But some of them are more or less complicated in their structure ; having a stomach and organs for motion.

Examples. Vibrio, volvox.

\section{CLASS MAMMALIA}

IS DIVIDED INTO EIGHT ORDERS.

1. Bimani, having two hands and cuspidate teeth.

Example. Man.

2. QuADlumaxi, having four hands and cuspidate teeth.

Examples. Ape, ourang-outang.

3. Carnivori, having cuspidate teeth, toes with nails and no thumbs.

Examples. Bat, hedgehog, shrewmouse, mole, bear, martin, dog, wolf, weazle, cat, leopard, seal, opossum.

4. Arrosores, (rongeurs) gnawers, or animals having incisors in both juws and no cuspidate teeth; toes with nails; feeding almost wholly on vegetable substances.

Examples. Beaver, rat, squirrel, hare.

5. EDentata, animals without incisors, and with hoof-like nails. 
Examples. Sloth, armadillo, duckbill.

6. Pachyderma, thick-skin animals, with hoofs and without clavicles.

Examples. Elephant, mastodon (extinct) hippopotanus, hog, rhinoceros, palentherium (extinct,) tapir, horse, zebra.

7. Ruminantes, animals which chew the cud, have incisors below only, and feet with cloven hoofs.

Examples. Camel, musk, deer, giraff, antelope, goat, sheep, ox.

8. CETE, aquatic animals, without any hind feet ; and whose fore feet are degenerated into fin-like limbs.

Examples. Whale, dolphin, porpoise, narwhal, physeter.

\section{CLASS AVES}

\section{IS DIVIDED INTO STX ORDERS.}

1. Accipitres, birds of prey. with strong hooked beaks and claws. They have jour toes; the thumb-toe, and the inner one of the other three are targest.

They are carnivorous; feeding on other birds, or small quadrupeds, reptiles, \&c.

Examples. Vulture, hawk, buzzard, eagle, owl.

2. Passenes, sparrou-like birds ; including all which are not swimmers, waders, or runners, climb. ers, birds of prey, or of the gallinaceous kind.

Examples. Grackle, fly-catcher, thrush, crow, oriole, warbler, wren, swallow, hum-bird, kingbird or bee-eater, king-fisher, lark, sparrow, robir, paradise-bird. 
3. Scansores, (grimpeurs,) climbers ; including those birds whose outer toe is directed backwards with the thumb-toe, by which they are supported in climbing and in fastening themselves to trunks of trees.

Examples. Woodpecker, wryneck, cuckoo, barbet, parrot, parrakeet.

4. Gallinaces, including all gallinaceous or henlike birds. Forward toes united partially at the base and jagged along their edges.

Examples. Peacock, turkey, pheasant, hen, grous, patridge, quail, pigeon.

5. Grallatores, (echassiers,) large-stepping birds, mostly with the two outer toes partially united.

They either wade in water or run on dry land. The strong-billed kind mostly live on fish; those with slender bills feed on insects.

Examples. Ostrich, lapwing, plover, oystercatcher, crane, stork, heron, boat-bill, ibis, spoonhill, woodcock, curlew, sand-piper, screamer, rail, coot, water-hen, fla mingo.

6. Anseres, (palmiperles,) feet palmate, mostly having the toes connected by membranes, and formed for swimming:

Examples. Diver, merganser, auk, penguin, petrel, albatross, gull, tern, skimmer, pelican, goose, duck, swan.

\section{CLASS AMPHIBIA}

IS DIVIDED INTO FOUR ORDERS.

1. Chelonia, reptiles with two auricles to the heart; having back shells and four feet. 
Examples. Tortoise, turtle, matmata.

2. SaURIA, reptiles having two auricles to the heart; covered with scales and having four feet.

Examples. Crocodile, lizard, basalisk, dragon, chamelion.

3. OpHidia, reptiles with two auricles to the heart, and destirute of feet.

Examples. Serpents or suakes, hydra and viper.

4. Batrachia, reptiles with one aurcle to the heart, body naked. and having four or two feet.

Examples. Frog, toad, tree-toad, salamander, proteus, siren.

\section{CLASS PISCES}

IS DIVIDED INTO SIX ORDERS.

1. A PODEs, * gill-membranes (if any) with long rays; ventral fins none.

Examples. Eel, sword-fish.

2. Jugulares, gill membranes with bony rays; ventral fins before the pectoral.

Examples. Corlfish, blenny.

3. Thoracici, gill membranes with bonyrays; zertebral fins under the pectoral.

Examples. Bullhead, flounder, hollibut, mackerel.

4. Abdominales, gill-membranes with long: rays; ventral fins buck of the pectoral.

Examples. Salmon, trout, sea-pipe, shad, carp.

* I adopt the orders of Linneus in this class; because, in my opin. ion, they are preferable to those of Cuvier, and will eventually be retoined. 
5. Branchrostegus, skeleton cartilaginous, without ribs; having gill membranes; with or without gill-covers.

Examples. Sucker, mullet, sun-fish.

6. Chondropterygious, skcietun cartilagenous, without ribs; gill-membranes wanting ; with or without gill-covers.

Examples. Lamprey, ray, shark, sturgeon.

\section{CLASS ANNELIDA}

IS DIVIDED INTO THREE ORDERS.

1. Tubicola, articulated, semi-mulluseous animals, with red blood, encased in calcareuns tubes.

Examples. Serpula or sea-pipe, amphitrite, tooth-shell or dentalium.

2. Dorsibranchia, back-gilled. Their respiratory organs ure distributed all along the body towards one side, called the back.

Ixamples. Nereis, aphrodite.

3. Abranchia, having no gills or other respiratory organs; but their respiration is performed by the entire surface of the skin.

Examples. Angle-worm, leech or blood-sucker, nais, gordius or hair snake.

\section{CLASS CRUSTACEA}

IS DIVIDED INTO FIVE ORDERS.

1. Decapodia, ten footed. Head confounded with the truni; eyes moveable; mandibles with palpi or feelers.

The gills are situated at the outer base of the feet. A numerous order.

Example. Crabs, lobsters. 
2. Stromapodia, body.footed. Head distinct from the trunk, and divided into two purts; and the fore part bears the antenna and the moveable eyes; mandibles bearing palpi.

The gills are plume-like.

Example. Crawish.

3. Amphifodia, feet all the length of the body. Head distinct from the body, being one piece only; cyes immovable; mandibles bearing palpi.

The gills or respiratory organs are vesicles situated at the interior base of the feet.

Example. Gammarus.

4. IsOPODIA, equal fooied. Head generally distinct from the irunk; mouth composed of several jaws; mandibles rvithout palpi, but the two lower jaus resemble a lip bearing tro palpi.

Gills or respiratory organs generally situated on the under side of the trunk.

Examples. Oniscus, sowbug.

5. BRanchirobrs, gills or respirable organs on the fin-like feet. Mouth is sometimes in the form of a beak, other times composed of many jaws ; no palpi.

Examples. Limulus, cecrops, cyclops.

\section{CLASS ARACHNIDA}

IS DIVIDED INTO TWO OLDLRS.

1. Pulmonalia, having pulmonary or respiratory sacks.

Examples. Aranea or proper spider, mygale, tarantula, scorpion.

2. Trachenia, respiratory organs are trachez. or radiated and branched tubes. 
Examples. Galeodes, shepherd or phalangita, mite or acorus.

\section{CLASS INSECTA}

IS DIVIDED INTO TWELVE ORDEIS.

1. Mrriapodia, many-footed. Wingless.

The number of their feet above six, disposed along the whole extent of the body upon a succes. sion of rings, one or two pair to each ring; the first and sometimes the second make part of the mouth.

Examples. Julus or round centipede, polydesmus, scolopendra or flat centipede.

2. Thysanoura, fringed. Wingless.

They walk upon but six feet; but they have other particular organs of movement along the sides or at the extremity of the body, giving it somewhat the appearance of being fringed or beset with bristles.

Examples. Lepisma, porlura.

8. Parasita, parasites, crazvling upon other animals. Wingless.

They have two smooth eyes; a snout enclosing a retractile sucker.

Examples. Pediculus or louse, ricinus or bird louse.

4. Sutorid, suckers. Wingless. The beak consists of a sucker enclosed in a cylindric sheath of. two articulated pieces.

Example. Pulex or flea.

5. Coleoptera, sheath-winged. Having four wings; the outer pair (called elytra) being crustaceous cases, and the inner pair folded trunsversely. 
They are the most numerous and best known of all insects. They are easily preserved, and make 2 beautiful appearance in cases under glass.

Examples. Cicindela, carabus, dytiscus, gyrimus, elater or taupin (the snap-bug) ptinus, hister, silpha, dermestes, (leather-chaffer) hydrophilus, (diver) scarabeus, (beetle) lytta, (blistering fiy) cerambyx, (goat-chaffer) coccinella, (lady-bird.)

6. Orthopters, strait-winged. Having four wings; the outer pair being generally coriaceous, and the inner pair paited longitudinally.

Their mandibles and jaws formed for mastication. They are all dry-land insects.

Examples. Forficula, (ear-wig) blatta, (cockroach) mantis, (soothsayer) phasma, (spectre) phyllum, (walking-leaf) gryllus, (grass-hopper locust.)

7. Hemiptera, half-ivinged. Having four wings; the upper part of the outer pair generally crustaceous, and the lower part membranaceous, and almost always crossing each other.

They have no jaws, but a sucking beak.

Examples. Cimex, (bug) nepa, (water-scorpion) notonecta, (boat-fly) fulgora, (fire-fly) thrips, aphis, (plant-louse) coccus, (cochineal.)

8. Neuruptera, nerve-winged. Having four naked membranaceous wings, finely reticulated; the inner pair as large as the outer, or larger one way.

Their mandibles and jaws are formed for mastication. Outer and inner wings alike.

Examples. Ephemera, (day-fly) panorpa, (scorpion-fly) myrmeleon, (lion-ant) hemerobius, (golden eye) raphidia, termes, (ticking insect) phryganea, (cadow-fly.) 
9. Hyminopter a, membrane-rvinged. Having four naked membranaceous wings ; the inner or pos. terior pair smaller than the others.

Their mandibles and jaws are formed for mas. tication. Outer wings less nerved than those of the neuroptera.

Examples. A large order.

Tenthredo, (saw-fly) cymbex, urocerata, (tailed-wasp) ichneumon, sphex, (solitary wasp) cynips, (gall-fly) chrysis, (golden. wasp) formica, (ant) vespa, (wasp) apis, (bee) libellula.

10. Lepidopter, scaly-rvinged. Having four membranaceous wings covered with small scales resembling dust.

They have a double coiled hollow tongue substituted for jaws. An elegant and extensive order.

Examples. Papilio, (butterfly) sphinx, (hawkmiller) phalæena, (candle-miller.)

11. Rhiptera, thrust-rvinged. Having two membranaceous wings plaited into a fain, with two small elytra-like or irustuceous moveable bodies near the origin of the membranaceous wings at the poste. rior part of the corslet.

They have two simple jaws in the form of bristles, with two palpi. These rare insects live between the scales on the bodies of some insects of the order of Hemiptera.

Examples. Xenos, stylops.

12. Diptera, truo-winged. Having two wings, mostly with poisers, being two moveable bodies, itn. der them.

The wings are membranaceous. They have no jaws, but have bristle-form suckers. 
Examples. Tipula, (crane-fly) culex, (guat) asilus, (hornet-fly) empis, boubilius, musca, (house-fly) tabanus, (great horse-fly) conops, oestrus, (gad-fly) hippobosca, (common horse-fly.)

\section{Class MOLLUSCA}

IS DIVIDED INTO FOUR ORDERS.

1. Nudata, destitute of a shell.

Examples. Slug or naked snail, cuttle-fish.

2. Multivalva, having shells with more than two valves.

Examples. Barnacles, acorn-shells.

3. Bivalva, having shells with two valves.

Examples. Clams, oysters, scollops.

4. Univalva, having shells with single valves.

Examples. Snails, conk-shells.

\section{CLASS ECHINODERMA}

IS DIVIDED INTO TWO ORDERS.

1. Pedicella, having stem-like organs, which are applied by the animals for the purpose of locomotion.

Examples. Asterias, (star-fish) echinus, (seahedgehogg) holothuria.

2. Apona, having no organs for locomotion.

Examples. Siponculus, molpadia, minyas.

\section{CLASS INTESTINA}

IS DIVIDED INTO TWO ORDERS.

1. Cavitoris, having internal cavities and a mouth. 
Examples. Ascaris, strongylus, lernæa, (gill. worms.)

2. Parenchymata, destitute of internal cavities and of mouths ; having pores for imbibing nutriment.

Examples. Fasciola (fluke) planaria, tænia, (tape-worm) scolex, ligula.

\section{CLASS ACALEPHA}

IS DIVIDED INTO TWO ORDERS.

1. Afrixata, fixed at their bases, at pleasure, though not often moving far.

Examples. Actinia (sea-anemone,) lucernaria.

2. Liberata, not fixed ; but swimming or floating from place to place.

Fixamples. Medusa (sea-nettle) berœ, cestrum.

\section{CLASS POLYP1}

IS DIVIDED INTO TWO ORDERS.

1. Nudata, naked polypi.

Examples. Hydra, (brachial polypus,) vorticella (flower polypus.)

2. Polypetra, stone-cased polypi.

Examples. Tubipora (tubipore coral,) sertularia (sea-moss, flustra (sea-mat,) cellepora, (cellepore coral,) corallina (coralline,) antipathos (seafan,) isis (jointed coral,) madrepora (madrepore coral,) millepora (many-pored coral,) retepora (net-mesh coral,) pennatula (sea-pen,) alcyonium. (fungus coral,) spongia (sponge.) 


\section{CLASS INFUSORIA}

IS DIVIDED INTO TWO ORDERS.

1. Rotipera, roundish or oval and having mouth and limbs.

Examples. Trichoda, brachionus, vorticella.

2. Homogenia, having neither mouth nor limbs, nor any viscera.

Examples. Cerearia, vibrio, monas, volvox. 


\section{$(58)$ \\ CLASS I. MAMMALIA.}

Remarks. This class is not entirely dependant on instinct ; for every animal of this class possesses faculties which enable it to accommon date its views to necessitous or restricted circumstances. Their lungs are divided into two lobes; and their trunks are divided transversely by a diaphragm. The part above the diaphragm contains the heart and lungs; the part below contains. the stomach and all that part of the alimentary canal, which is below the apper opening into the stomach.

The animals of this class have the most complicated structure and the most delicate sensations; consequently are subject to the greatest variety of disease. Their desires are multifarious; and while seeking their gratification, they bring into operation and greatly perfect all their various functions. Their brains are larger than those of other classes which have brains; and a slight derangement of the brain destroys life.

\section{The class MAMMALIA is bIVIDed inte} EIGHT ORDERS.

\section{ORDER 1. BIMANE.}

Having two hands and cuspidate teeth. Feeding on animal and regetable substances.

Hомо, (man) body erect, and sustained upon two feet; face nearly vertical, or forming an angle of more than seventy degrees with the basis of the cranium. 


\section{ORDER 2. QUADRUMANI.}

Having four hands and cuspidate teeth.

Simia, (ape, monkey, ourang-outang,) front teeth four in each jaw, placed near together ; canine teeth solitary, longer than the others, distant from the remaining teeth or grinders ; grinders obtuse.

LEMur, (macauco ape,) front teeth in the upper jaw four, intermediate ones remote : in the lower jaw six, longer, stretched forward, compressed, parallel, approximated ; canine teeth solitary, approximated; grinders several, somewhat lobed, the foremost somewhat longer and sharper.

Remarks. This order of animals approaches the first order in some particulars. But they are decidedly quadrupeds; as they al ways walk upon four legs. They have four hands, though they walk upon them. For the thumb is always placed opposite to the other fingers, as in the human hand-never parallel to them like the first toe of a foot.

The brain differs widely from the human brain. The cerebrum is divided on each side into three lobes, whereas the human brain consists of one lobe only on each side.

\section{ORDER 3. CARNIVORI.}

Having cuspidate teeth, and toes with nails, but no thumbs; feeding more or less on animal substances.

Sec. A. Wing-footed animals.

Vespertilio, (bat, flying-mouse, teeth erect, sharp-pointed, approximated, hands palmated 
with a membrane surrounding the body, giving the animal the power of flying.

Gallopithecus, (flying-cat,) front teeth in the upper jaw none ; in the lower one 6, short, broad, distinct, pectinated; canine teeth very short, triangular, broad, sharp, serrated ; grinders 4, truncated and muricated, with conical protuberances; flying skin surrounding the body, limbs, and tail.

Sec. B. Insect-eaters, issuing out in the night in search of food; walk slow.

Erinaceus, (hedge-hog,) front teeth 2, both above and below; those of the upper jaw distant; of the lower approximated ; canine teeth on each side, in the upper jaw.5, in the lower 3 ; grinders on each side 4 , both above and below ; body covered on the upper part with spines.

Sorex, (shrew-mouse,) front teeth in the upper jaw 2, long and bifid; in the lower 2 or 4 , the intermediate ones shorter ; canine teeth several on each side ; grinders cuspidate.

Talpa, (mole,) front teeth in the upper jaw 6 , unequal; in the lower jaw 8, canine teeth one on each side, the upper ones largest; grinders 7 in the upper jaw, 6 in the lower.

\section{Sec. C. Proper flesh-eaters.}

Ursus, (bear, badger, raccoon,) front teeth 6 , above and below, the two lateral ones of the lower jaw longer than the rest and lobed, with smaller or secondary teeth at their internal bases ; canine teeth solitary; grinders 5 or 6 on each side, the first approximating to the canine; tongue smooth ; snout prominent; eyes furnished with a nictitating membrane. 
Lutra, (otter,) incisors 6, sharpish ; caniue teeth longer ; feet webbed.

Canis, (dog, wolf, fox, hyena, incisors in up. per jaw 6 ; latteral ones longer, distant ; intermediate ones lobated; in lower jaw 6 ; lateral ones lobated; canine teeth solitary, incurved; grinders 6 or 7 , (or more than the other genera of this order.)

Viveria, (weesel, skunk, civit,) incisors 6, sharpish; canine teeth longer; tongue in some smooth, in others aculeate backwards ; body of a lengthened form.

Feuis, (cat, lion, tiger, panther, lynx, front teeth 6 ; intermediate ones equal; grinders three on each side ; tongue aculeated backwards ; claws retractile.

Sec. D. Amphibious carnivorous animals.

Phoca, (seal,) fore-teeth in the upper jaw 6, pointed, parallel; exterior larger ; in lower jaw 4, bluntish, parallel, distinct, equal ; canine teeth, one on each side, in both jaws, large, pointed; upper ones distinct from the incisors, the lowes ones distinct from the grinders; grinders 5 on each side above, 6 below, obtusely tricuspidate.

Trichechus, (morse, sea-cow, sea-horse, walrus, ) fore teeth (in the full grown animal) none, either above or below ; tusks solitary in the upper jaw; grinders with wrinkled surfaces; lips doubled; hind feet at the extremity of the body, unit ing into a fin.

Sec. E. Pouched carnivorous animals.

Didelphis, (oppossum, front teeth small, rounded ; superior 10, the two middle ones longer; 
inferior 8 , the two middle ones broader and very short; canine teeth long; grinders deuticulated; tongue ciliated with papillæ; teats (in most species) contained in an abdominal pouch.

Macropus, (kangureo,) front tecth in upper jaw 6, (in young ones 8,) emarginated ; in lower jaws 2, very large, long, sharp, and pointed forward ; grinders 5 on each side, both in upper and lower jaw, distant from the other teeth; fore legs very short; hind legs very long; the female having an abdominal pouch.

\section{ORDER 4. ARROSORES.}

Having incisors in both jaws and no cuspidate teeth ; toes with nails ; feeding almost wholly on vegetable substances. They are the proper gnawers.

Castor, (beaver, incisors in the upper jaw truncated and excavated with a transverse angle ; in the lower jaw transverse at the tips; grinders on each side 4 ; tail long, depressed and scaly; has collar bones.

Mus, (rat, mouse, upper incisors wedge-form; grinders 3 on each side, rarely 2 ; having collar bones.

Mroxus, (dormouse, incisors 2, upper wedgeform, lower compressed; grinders 4 in each jaw ; vibrissæ long; tail cylindric, villose, thicker towards the end ; legs of equal length ; 4 toes to each fore foot.

Dipus, (long-foot mouse,) incisors 2 above and 2 below; fore legs very short, hind legs very long; having collar bones.

Arctomys, (rat-bear,) incisors 2 in each jaw, strong, sharp, wedge-form ; grinders in upper jaw 
5 on each side; in lower jaw 4: having collar bones.

Scrurus, (squirrel,) incisors in upper jaw wedge-form, in lower jaw sharp; grinders 5 on each side in upper jaw, 4 in lower jaw; having collar bones ; tail spreading towards each side in most species.

Hystrix, (porcupine,) incisors 2 , both in upper and under jaw, obliquely cut; grinders 8; body covered with spines intermixed with hair; 4 toes to each fore foot, 5 to each hind foot.

LEPUS, (hare, rabbit,) incisors 2 above and 2 below, the upper pair duplicate; two small interior ones standing behind the exterior.

Cavia, (guinea-pig, india-pig,) incisors 2, wedge-form; grinders 8 ; toes 4 or 5 to each fore foot, to each hind foot 3 to 5 ; tail none or very short ; collar bones, none.

\section{ORDER 5. EDENTATA.}

Having no incisors, and having hoof-like nails.

Bradirus, (sloth, cutting teeth none in either jaw ; canine teeth obtuse, single, longer than the grinders placed opposite; grinders 5 on each side, obtuse; fore legs much longer than the hind ones: claws very long.

Megatherium, (extinct genus, ) teeth flat-topped; forelegs equal in length to both head and neck; claws long. Intermediate in character between Bradypus and Dasypus.

DAsypus, (armadillo, grinders several, without either the cutting or canize teeth ; body coated with a shelly armour, divided into zones.

Mrrmecophaga, (ant-eater, teeth none ; tongue cylindric, extensile; mouth lengthened into somewhat tubular form ; body covered with hair. 
Manis, (scaly hizard, pangolin,) teeth none; tongue cylindric and extensile; mouth narrowed into a snout; body covered with scales.

Platypus, (duck-mouth,) mouth shaped like the bill of a duck; feet webbed.

\section{ORDER 6. PACHYDERMA.}

Having hoofs and no clavicle; skin very thicl.

ElepHas, (elephant,) cutting teeth none in either jaw ; tusks in the upper jaw ; grinders composed of vertical plates of a bony substance; pro. bocis very long, prehensile ; body nearly naked.

Mastodon, (extinct animal,) grinders have a bristly crown, or a sort of gum, with thick conic points. Other teeth mostly like those of the elephant.

Hyppopotamus, (river horse, ) incisors 4 in each jaw, above distant in pairs, below prominent and the two middle ones longest; canines solitary; below extremely large, long, curved, and obliquely truncated; feet armed at the margin with each. 4 hoofs.

Sus, (swine,) incisors above 4, converging; below 6 , projecting; canines below 2 , long exsert: above 2, shorter ; snout truncated, prominent, moveable ; feet cloven.

ANoplotheriun, (extinct animal,) incisors 6 in each jaw ; four canine teeth resembling the incis. ors : twenty-eight grinders forming a continued series, like those of the human teeth. Feet terminate in cloven hoofs. This animal must have borne considerable resemblance to animals of the order Ruminantes.

Rhinoceros, (rhinoceros,) one or two horns, solid, perennial, conical, seated on the nose, and 
srowing from the skin; feet terminate in three toes.

Hyrax, (cape-badger, lamb of Israel, ) incisors above two, broad, somewhat distant; below 4, broad, flat, doubly notched ; grinders large, 4 on each side of each jaw ; 4 toes to each fore foot, 3 to each hind foot ; tail none ; collar bones none.

Paleotherium, (extinct animal) incisors six, and canine teeth two in each jaw ; feet terminate in three toes; trunk, or proboscis, must have been short and fleshy.

TAPIR, (tapir, incisors 10 above and below? canines single, and incurvated; grinders 5 on each side, very broad; 3 hoofs to each foot, with a false one on the fore foot.

EquUs, (horse, zebra,) incisors above 6, parallel, below 6, somewhat projecting; canines 1 on each side above and below, remote from the rest; hoofs undivided.

\section{ORDER VII. RUMINANTES.}

Incisors below only; feet with cloven hoofs ; animals chew the cud.

Camelus, (camel, dromedary, horns none; incisors below 6, somewhat thin and broad; canines 3 above, 2 below, distant ; upper lip divided.

Moschus, (musk, ) horns none ; incisors below 8 ; tusks in the upper jaw exsert, solitary.

Cervus, (deer, stag, elk, moose,) horns solid, (covered while young with a hairy skin growing from the top) naked, annual, branched; incisors below 8 ; canines none (sometimes a single one) in the upper jaw. 
EAmelopardaris, (giraffe,) horns permanent, hony, covered with bristly skin; incisors below 8 ; the exterior one on each side deeply bilobate. Antelope, (antelope,) horns hollow, seated on a bony core, growing upwards, annulated or wreathed, permanent; incisors below 8 , canines none.

Capra, (goat, ibex,) horns hollow, turning upwards and backwards, compressed, rough, al. most closed at their base ; incisors below 8 , caaines none; chin bearded in the male.

Ovis, (sheep,) horns hollow, wrinkled turning backwards and spirally intorted; incisors 8 , below; canines none.

Bos, (ox, bison, buffalo,) horns concave, turned outwards, lunated, smooth ; incisors 8 , below: canines none.

\section{ORDER VIII. CETE.}

Aquatic animals, without hind feet ; fore feet degenerated into fin-like limbs.

Desphinus, (dolphin, porpoise, teeth in both jaws; spiracle on the head.

Monowon, (narwhal,) tooth projecting from the upper jaw, very long, strait, spiral ; spiracle on the head.

Physeter, (cachelot,) teeth visible in the lower jaw only; spiracle on the head or snout.

Bal a ena, (whale, hoiny laminze in the upper jaw in place of teeth; spiracle with a double external orifice on the top of the head. 


\section{$(62)$}

\section{CLASS II. AVES.}

Remarks. Animals of this class do not have their lungs divided into lobes - the whole being in a single mass. Neither are their lungs ventilated by their own contractions and dilatations. Air is made to pass through them by the action of other organs. It is admitted to the blood by an infinite number of vessels from the axils of the wings and various other parts of the body.

Their forms are adapted to their peculiar circumstances; they being the only animals of this grand division which travel in the atmosphere. The muscles of the breast are very large and strong, giving great force to their wings. Their covering of feathers, being non-conductors of electric fluid, secures them in some measure against its frequent discharges in the form of lightning in the upper regions; and more especially when sitting upon their nests, on high trees.

Their rapid passage through different regions of the air, and its perpetual action upon them, afford them the means of prognosticating the variations of the atmosphere by a method totally unknown to us.

THE CLASS AVES IS DIVIDED INTO SIX ORDERS.

\section{ORDER I. ACCIPITRES. Ra paces}

Having strong hooked beaks and claws; toes 4 ; the thumb toe, and inner one of the other three, are larger. Birds of prey.

VuLTuR, (vulture, bill straight, hooked at the tip, and covered at the base by a cere or skin; 
head, in most species, bare of feathers, and covered in front by a naked skin; tongue fleshy and generally bifid ; neck retractile ; feet strong with moderately crooked claws.

FAcco, (hawk, buzzard, kite, eagle, beak hooked, furnished at the base with a cere; head well covered with feathers; tongue, in most species, bifid.

Serpentarius, (snake-eater, ) beak vulturine ; tongue pointed : legs very long.

STrix, (owl,) bill hooked, without cere ; nostrils oblong, covered with recumbent setaceous feathers ; head, eyes, and ears, large ; tongue bifid; exterior toe moveable backward and forward.

\section{ORDER II. PASSERES.}

Including all birds, which are not swimmers, ruaders, runners, climbers, birds of prey, or of the gallinaceous kind. They are all of the sparroulike family.

Section A. Bills indented. Onsection

LANıus, (shrike, butcher-bird,) bill straightish, with a tooth or staall process on each side near the tip ; tongue jagged ; outside toe connected to the middle one, as far as the first joint.

Tanagra, (tanager, ) bill conic, pointed, notched, almost triangular at the base, a little inclining at the tip.

Muscicapa, (fly-catcher, cat-bird,) bill nearly triangular, notched each side, bent in at the tip, and beset with bristles at the root; toes (mostly) divided to their origin.

Ampelis, (chatterer, bill straight, convex; each mandible notched; nostrils covered with 
bristles ; tongue sharp, cartilagenous, bifid ; middle toe connected at the base to the outermost.

TuRdus, (thrush, bill straitish, the upper mandible a little bending and notched near the point; nostrils naked, or half covered with a small membrane; mouth ciliate with a few bristles at the corners ; tongue jagged.

Oreolus, (oriole, fire-bird, red-robin,) bill conical, convex, very sharp-pointed, strait ; upper mandible a trifle longer than the lower one, and obscurely emarginated ; tongue bifid, sharp ; feet formed for walking.

Gracula, (grakle, black-bird,) bill eonvex, thick, somewhat compresserl on the sides, coulterform ; nostrils small, near the base of the bill, often near the elge ; tongue entire, rather sharppointed, fleshy ; feet formed for walking ; middle toe connected to the outmost toe at the base.

PrrRA, (manakin,) bill shorter than the head, strong, hard, nearly triangular at the base, and slightly incurved at the tip; nostrils naked; feet gressoral ; tail short.

Motacilla, (wren, warbler, sparrow, robbin,) bill subulate, strait; mandibles nearly equal: nostrils obovate ; tongue lacerate at the end.

Section B. Bills deeply separated, short, flat hooked, without notches. (Chelidone)

Hinundo, (swallow, martin,) bill small, weak, curved, subulate, depressed at the base; gape larger than the head ; tongue short, broad, cleft ; wings long; tail mostly forked.

Caprimulgus, (goat-sucker, night-hawk, whippoor-will,) bill slightly curved, very small, subilate, and depressed at the base ; mouth extremely 
wide and furnished at the sides with a series of bristles ; ears very large ; tongue pointed, entire ; tail not forked, feathers 10 ; legs short; middle claw with a broad serrate edge.

Section C. Bills strong, conic, without notches. Cnnwoles and brencuver.

ALAUDA, (lark, ) bill cy lindrical, subulate, strait; the mandibles equal and a little gaping at the base; tongue bifid; hind-claw strait, longer than the toe.

Parus, (titmouse,) bill very entire, narrow, subcompressed, strong, hard, pointed, and covered at the base with bristles; tongue truncate, bristly at the end ; toes divided to the origin, the hind one large and strong.

Emberiza, (bunting, bill conic ; mandibles receding from each other from the base downwards, the lower with the sides narrowed in ; the upper with a hard knob within.

Fringilla, (fiuch, sparrow, linnet,) bill conic, strait, pointed.

Phytotoma, (squaller,) bill conic, strait, serate; nostrils oval ; tongue short, obtuse; feet four-toed.

Loxia, (grosbeak, goldfinch, crossbill,) bill strong, thick, convex, rounded at the base ; lower mandible bent in at the edge; nostrils small, round at the base of the bill ; tongue truncate.

Cousus, (coby,) bill short, thick, convex alıove, flat beneath ; upper mandible bent down at the tip ; nostrils small at the base of the bill and nearly covered with feathers; tongue jagged at the tip ; tail long, wedge-form.

GLAUCOPIS, (wattle-bird,) bill incurvated, arched, the lower mandible wattled beneath at the base; nostrils depressed, half covered by a subr. 
cartilagenous membrane: tongue semi-cartilagenous, notched and ciliated at the tip ; feet formed for walking; three toes before and one behind.

Buphaca, (beef-eater, bill strait quadrangular: mandibles gibbose, entire, more gibbose on theoutside; legs formed for walking.

Stuinus, (starling, bill subulate, angular, depressed, bluntish ; the upper mandible entire. somewhat open at the edges; nostrils surrounded. with a prominent rim ; tongue notclied, pointed.

SitTA, (nut-cracker, nut-hatch, bill straight, wedged at the top, subulate, roundish, entire ; upper mandible a little longer, compressed and angular at the tip ; tongue jagged, short, horny at tip ; nostrils small, covered with bristles; feet formed for walking, hind toe long.

Convus, (crow, raven, jay, magpie, jacklaw, bill convex, strong, coulter-form, and (in most species) toothed or notched near the tip; nostrils covered by recumbent bristly feathers; tongue oartilaginous, bifid ; feet formed for walking.

Coracias, (roller, ) bill nearly straight, bending a little towards the end, cultrated at the edges; nosbrils narrow, naked ; tongne cartilaginous, bifid : legs generally short; toes divided to their origin, three forward and one backward.

Paradisea, (paradise bird,) bill covered at the. hase by velvet-like plumes; side-feather's beneath the wings (in most species) extending, far beyond the rest of the plumage; legs strong; feet formed for walking. 
Section D. Bills slender, long, more or less arched and without notches. Cnyrodacty $i$

Upups, (hoopoe, messenger-bird,) bill arched, long, slender, convex, a little compressed, somewhat obtuse; nostrils at the base of the bill, small ; tongue obtuse, entire, triangular, very short ; feet formed for walking.

Certhia, (creeper, bill arched, slender, somewhat triangular, pointed; tongue various, generally pointed ; feet formed for walking.

Trochilus, (humming--ird,) bill subulate filiform, tubular at the tip, longer than the head; upper mandible sheating the lower ; tongue filiform, the two threads cualescing, tubular; feet formed for walking.

Section E. Equal toes, or the outer toe about as long as the middle ane.

Merops, (bee-ealer, bill curved, quadrangular, compressed, carinate, pointed; nostrils small at the base of the bill ; tongue slender, tip (general. ly) jagged ; feet gressoral.

Momotus, (motnot, bill strong, slightly curred, serrate at the edges; nostrils feathered; tongue feathered; tail wedged.; feet gressoral.

Alceno, (king-fisher, bill triangular, thick, strait, long, pointed ; tongue fleshy, very shart, flat, pointed ; feet (in most) gressoral.

'Tonus, (tody,) bill subulate, depressed, obtuse, straight, covered at the base with bristles ; nos. trils oval, small ; feet gressoral.

Buceros, (hornbill,) bill convex, curved, sharpedged, large, sertate outwardly, with a horny protuberance on the upper. mandible near the base ; 
nostrils behind the base of the bill ; tongue short, sharp-pointed ; feet gressoral.

ORDER 3. SCANSORES. Z yqudae

Having the outer toe and thumb-toe directed backwards, for climbing the trunks of trees.

GaLbULA, (golden thrush,) bill straight, very long, quadrangular, pointed; nostrils oval, at the base of the bill; tongue short, sharp-pointed; thighs downy on the fore part; feet climbers.

Pieus, (wood-pecker,) bill angular, straight, wedge-form at the tip ; nostrils covered with recumbent setaceous feathers; tongue round, wormform, very long, bony, missile, daggered, beset at the point with bristles bent back ; tail feathers ten, hard, rigid, pointed; feet climbers.

YuNx, (wry-neck, bill smoothish, pointed, a little incurved, weak; nostrils concave, naked; tongue very long, smooth, worm-form, armed at the point ; tail feathers 10, flexible ; feet climbers.

Cuculus, (cuckoo, bill smooth, a little curved; nostrils surrounded by a small rim ; tongue arrowed, short, pointed; feet formed for climbing.

Scrturops, (channel-bird,) bill large, convex, sharp-edged, channelled at the sides, hooked at the point; nostrils naked, rounded at the base of the bill ; tongue cartilagenous, split at the point; feet climbers.

Bucco, (barbet,) bill sharp-edged, laterally: compressed, notched each side near the tip, bent inwards and a long split beneath the eyes; nostrils covered with incumbent feathers ; feet formed for climbing. 
Trogon, (curuke,) bill shorter than the head, sharp edged, hooked, the mandibles serrate at the edge ; feet formed for climbing.

Crotophaga, (giant blackbird,) bill compressed, semioval, arched, carinate on the back; upper mandibles angular at each edge; nostrils pervious.

Rhamphastos, (toucan,) bill enormous, empty, convex, serrate at the edges; each mandible incurvate at the tip; behind the base of the bill, long, narrow ; tongue feathered at the edges ; feet mostly climbers.

Psitracus, (parrot, ) bill hooked, upper mandible moveable, (mostly) covered with a cere ; nostrils rounded, placed in the base of the bill; tongue fleshy, obtuse, entire ; feet formed for climbing.

\section{ORDER 4. GALLINACES.}

Having the forward toes united partially at the base, and jagged along their edges. Hen-like birds.

$$
\text { Yallinacer }
$$

iolureche

Pavo, (peacock, bill convex, robust ; head covered with revolute feathers; nostrils large; feathers of the rump long, broad, expansile and covered with eye-form spots.

Meleagris, (turkey,) bill conic, incurvate ; head covered with spougy caruncles; chin with a longitudinal membranous caruncle; tail broad, expansile ; legs spurred.

Crax, (carassow, peruvian hen, bill strong, thick, the base of each mandible covered with a cere; nostrils in the middle of the cere; feathers covering the head, revolute; tail large, straight, expansile. 
Penerore, (jacu-turkey, bill naked at the base : head covered with feathers; chin naked; tail with 12 feathers; legs without spurs.

Phasianes, (hen, pheasant, bill short, strong; cheeks covered with a smooth naked skin; legs generally with spurs.

Numidia, (guinea-hen,) bill strong, short; the base covered with a carunculate cere receiving the nostrils ; head horned, with a compressed, coloured callus ; tail short, bending down; body speckled.

Tetrao, (partridge, quail, grous,) near the eyes a spot which is either naked, papillose or (very rarely) covered with feathers.

Columa, (pigeon, dove, turtle-dove,) bill straight, descending towards the tip ; nostrils oblong, half covered with a soft timid membrane.

\section{ORDER 5. GRALLATORES.}

Having the two outer toes partially united. rong-legged walking bivids. Cursores.

Section A. Short-winged.

STrutho, (ostrich, cassowary, bill subconic ; nostrils oval; wings short, unfit for flight; feet formed for runniug:

Dives, (dodo,) bill narrowed in the middle, with two transverse wrinkles; each mandible bent in at the tip : nostrils oblique, near the edge of the middle of the bill ; face naked beyond the eyes; legs short; feet cleft; wings unfit for 'Aight; tail none. 


\section{Section B. Compressed bill.}

Oris, (bustard,) bill subconvex; nostrils oval, pervious ; tongue bifid, pointed ; feet formed for running, three toed, tall, naked above the thighs.

Curarandrius, (plover, snipe, bill roundish, olutuse, straight ; nostrils linear ; feet formed for running; three toed.

Tringa, (sand-piper,) bill roundish, as long as the head; nostrils small, linear ; tongue slender; feet four-toed ; the hind toe of one joint, and rais. ed from the ground.

Haematopus, (oyster catcher, bill compressed, the tip an equal wedge; nostrils linear; tongue a third part as long as the bill; feet formed for running; three toed, cleft.

\section{Section C. Coulter-bill.}

Psopura, (trumpeter,) bill cylindrical, conic, convex, somewhat pointed; upper mandible longer; nostrils oval, pervious ; tongue cartilaginous, fiat, fringed at the tip ; feet four-toed, cleft.

Canckoma, (boat-bill,) bill gibbose, shaped like an inverted boat ; nostrils s mall, placed in a furrow ; tongue small; toes divided.

ARDEA, (heron, crane, stork, bittern,) bill straight, pointed, long, subcompressed, with a furrow from the nostrils towards the tip ; nostrils linear; tongue sharp; feet four-toed, cleft, toes connected at the base.

Mxcteria, (jabiru,) bill a little bending upwards, sharp-pointed; upper mandible triangular; front bald ; nostrils linear ; tongue small or none; feet four-toed, cleft.

Scorus, (umbre, bill long, thick, compressed, 
a little hooked ; nostrils linear, oblique ; feet fourtoed, cleft.

- Tantalus, (ibis, bill long, subulate, roundish, subarched; face naked; tongue short, broad; jugular pouch naked ; nostrils oval ; feet four-toed, pulminate at the base.

Platalea, (spoon-bill,) bill long, thin, the tip dilated, orbicular, flat ; nostrils small, at the base of the bill ; tongue short, pointed ; feet-four toed, semi-palmate.

Corrina, (racer,) bill short, straight, without teeth ; thighs longer than the body ; feet fourtoed, palmate, the hind toe not connected.

\section{Section D. Long-bill.}

Scolopax, (snipe, woodcock, curlew, bill roundish, obtuse, longer than the head ; nostrils linear; face covered; feet four-toed, hind toe consisting of many joints.

Recurvirostra, (yelper, scooper, a voucet,) bill depresscd, subulate, recurved, pointed, flexible at the tip ; feet palmate, four-toed, the hind toe not connected, very short and placed high up ; nostrils narrow, pervious ; tongue short.

Section E. Long-toed.

Parra, (jacana, bill tapering, somewhat obtuse ; nostrils oval, in the middle of the bill ; front covered with lobate caruncles ; wings spinose.

Vaginalis, (sheath-bill,) bill strong, thick, conic-convex, upper mandible covered above with a moveable horny sheath; nostrils small, before the sheath ; face naked, papillose ; legs strong, fourtoed, naked above the knees ; claws grooved. 
Palamedea, (screamer, bill conic ; upper mandible hooked; nostrils oval; feet four-toed, cleft, a very small membrane connecting the toes at the root.

Rallus, (rail, crake, water-hen,) bill thickish at the base, attenuated on the back towards the tip, compressed, a little incurved, pointed ; tongue rough at the tip; body compressed ; tail short; feet four-toer, cleft.

Fulica, (coot, rain-hen, gallinule, bill convex, upper mandible arched over the lower at the edge, lower gibbose near the tip ; nostrils oblong; front bald ; feet four-toed, subpinnate.

Glareola, (sea-swallow, bill strong, short, strait, hooked at the tip ; nostrils at the base of the bill, linear, oblique; gape of the mouth large; feet frum-toed; toes long, slender, connected at the base by a membrane ; tail forked, consisting of 12 feathers.

Phoenicopterus, (flamingo, bill naked, toothed, bent as if broken; nostrils linear ; feet fourtoed, palmate, the membranes semicircular on the fore part; hind toe not connected.

\section{ORDER 6. ANSERES.}

Having palmate feet, with toes connected by membranes in most cases; formed for swimming.

Section A. Divers, with feet far back; requiring a position nearly erect for balancing the body.

Colymbus, (diver, loou, grebe, bill toothless, subulate, straight, pointed ; throat toothed; nostrils linear at the base of the bill ; legs fettered. 
Alca, (awk, bill toothless, short, compressed, convex, often transversely furrowed ; lower mandibles gibbose near the base ; nostrils linear; legs mostly three-toed.

Arte^onyta, (penguin,) bill straight, a little compressed and sharp-erlged, upper mandible longitudinally, obliquely grooved, the lower truncate at the tip; tongue with reflected prickles; wings fin-form, without quill-feathers; feet fettered, four-toed.

Section B. Long-vinged flying sea birds.

Procellaria, (petrel,) bill toothless, a little compressed, hooked at the point; mandibles equal; nostrils cylindrical, tubular, truncate, lying on the base of the bill ; feet palmate ; the back toe pointing downwards, sessile, sharp, a mere spur.

Diomedea, (albatross, man-o-war bird,) bill straight, upper mandible hooked at the point, lowor truncate ; nostrils oval, wide, prominent, lateral; tongue very small; feet four-toed, all placed forward.

Larus, (gull, sea-mew, bill straight, sharpedged, a little hooked at the tip, and without teeth; lower mandible gibbose below the point ; nostrils linear, broader on the fore part, and placed in the middle of the bill.

STERNa, (tern, noddy, bill subulate, straightish, pointed, a little compressed, without teeth ; nostrils linear; tongue pointed; wings very long; tail mostly forked.

Rhynchors, (skimmer,) bill straight ; the upper mandibles much shorter; the lower truncate at the tip. 


\section{Section C. Feet wholly palmated.}

Pelicanus, (pelican, cormorant, shag, booby, ) bill straight, hooked at the point and furnished with a nail; nostrils an obliterated slit ; face nakedish ; legs equally balancing the body ; all the four toes palmate.

Plotus,(darter,) bill straight, pointed, toothed; nostrils with a slit near the base; face and chin naked ; legs short; all the toes connected.

Pheton, (tropic bird,) bill elharp-edged, straight, pointed, the gape of the mouth reaching beyond; nostrils oblong; hind toe turned forward.

Anas, (goose, duck, swan, teal,) bill convex, obtuse, the eflges divided into lamellate teeth, tongue fringed, obtuse ; three fore-toes connected, hind one solitary.

Mergus, (merganser, goosander, nun,) bill toothed, slender, cylindrical, hooked at the point ; nostrils small, oval, in the middle of the bill : fcet four-toed, outer toe longest. 


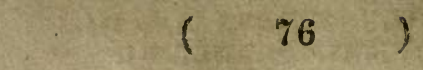

\section{CLASS III. AMPHIBIA.}

Remarks. The blood of animals is rendered warm and capable of exciting nervous action by the process of respiration. Amphibious animals have their circulatory system so arranged, that but a part of the blood passes into the lungs; consequently does not receive the benefit of free respiration. The necessary deficiency in the warmth and in the exciting power of the blood, predisposes them to a torpid state. And though some of them move with rapidity at times; they are generally torpid, their digestion slow, their senses dull, and some of them pass the winter in a lethargic state. Fiven if the lead is separated from the body, life is still manifested by muscular action for a lung time. Their pulmonary vessels are so small, and respiration so slow, that they may remain long under water without producing any change in the circulation of the blood.

\section{ORDER 1. CHELONIA.}

Having a covering consisting of a shell on the back and on the breast, and walking or swimming with four feet. Heart with two auricles.

Testuno, (tortoise, body defended by a bony covering, or coated by a horny, scaly or coriaceous integument; mouth with a sort of serrate mandibles, and not proper teeth; the upper mandible. closing over the lower, 
CLASS III. ORDERS II \& III.

\section{ORDER 2. SAURIA.}

Having a covering of scales, and walking on two or four feet. Heart with two auricles.

Lacerta, (lizard, crocodile, chamelion,) body four-footer, elongated, tailed; without any secondary integument.

Draco, (dragon, body four-footed, tailed, and furnished on each side with an expansile, radiate, wing-like skin.

\section{ORDER 3. OPHIDIA.}

Having no feet. Heart with two auricles.

Anguis, (slow-worm, scales both on the abdomen, and beneath the tail.

Amphisbaena, (itch-worm, ) body cylindric, equal ; annular divisions both on body and tail.

BoA, (giant snake,) scuta, or undivided plates, both on the abdomen, and beneath the tail.

Coluber, (viper, asp, ring-snake, green-snake, spotted-snake, striped-snake, scuta, or undivided lamellæe under the abdomen; broad alternate scales, or divided laminæ, under the tail.

Acrochordus, (warted-snake, body and tail completely covered with warts.

Hrdrus, (water-snake, body slender in front, gradually thickening, scaled ; tail compressed.

Crutalus, (rattle-snake, scuta on the abdomen; scuta and squamæ beneath the tail ; rattle terminating the tail.

Langaya, (moccasin-snake,) abdominal plates ; caudal rings ; terminal scales.

Caecilia, (eel-snake,) body cylindric, equal; wrinkles on the sides both of the body and tail. 


\section{ORDER 4. BATRACHIA.}

Having no covering of shells or scales, and fursished with two or four feet. Heart with one awricle.

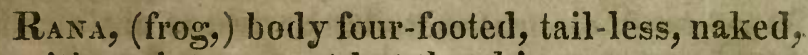
or with no integument but the skin.

Salamandra, * (salamander, rain-newt, ) body elongated, four-footed, tail long; head fiat, ears concealed under the skin ; 4 toes before, 5 behind.

Proteus, (mud-dragon, body elongated, fourfooted ; tail compressed vertically; legs short, three toes on the fore feet and two toes on the hind feet.

Siren, (siren,) body elongated, two-footed beiore, no feet behind ; feet with five toes.

* These three last genera have the general form of lizards; but they fare single auricles and naked bodies, or nearly naked. 


\section{$(79)$}

\section{CLASS IV. PISCES.}

Remarks. In this class the process answering to respiration is performed by presenting the blood to the air contained in water by means of the gills. In effect the gills are as lungs exposed inside out. Fish cannot live in water, from which air has been expelled by boiling, until it has been exposed a considerable time to the atmosphere, or been agitated in it. They take water into the mouth and compress it upon the gills by the gill-covers ; whereby they bring the air contained in it into close contact with the gills.

Most species of fish have an air-vessel which they can compress and dilate at pleasure; by which operation they ascend and descend in water without much exertion. They move in water by their fins, which they use like oass, or wings. Those fins which answer to fore feet are called pectoral fins - to hind feet, caudal fins - those on the back, dorsal fins - those near the vent, anal fins - those of the abdomen, ventral fins. The ribs in the fins and gills are called rays. These rays. are thorny, soft, articulated, or branched.

Some fish are migratory like birds; as the shad. They move in vast numbers from the ocean into fresh water rivers in the spriug season, and deposite their eggs. Some reside permanently in fresh water, some in salt water, and others seem to live in either indifferently. Those which pass into fresh water rivers in the spring season, encrease in number in proportion to the extent of agricultural improvement in the countries through which the rivers run. The shad of the Hudson have en- 
creased probably from five to ten fold within the last century. Probably the encrease of animal substances, along the river and its tributary branches, which are perpetually washed into it, furnishes an immense addition to the stock of food suited to their natures.

Most fish feed on both animal and regetable substances. Some species will live many years in a vessel of mere water. Whether they possess the power of decomposing water and forming new. compounds fit for food, or whether the water absorbs organized matter from the atmosphere sufficient to support them, or on what other principle their lives are prolonged in this situation, is not determined. But the same difficulties present themselves in regard to the leach and numerous. other avertebral animals ; excepting that the latter have a less complicated organization.

\section{ORDER 1. APODES.*}

Gill-membranes (if any) with long rays; ventral fins none.

Anguilla, (eel,) head smooth ; nostrils tubular; eyes covererl by the common skin ; gill-membranes 10-rayed; body roundish, smooth, mu* cous ; dorsal, caurlal, and anal fins united; spiracles (breathing holes) behind the head or pectoral fins.

Muraena, (eel, serpent-eel, body eel-form; pectoral fins none; spiracle on each side of the neck.

* I prefer the orders of Linneus in this class, for reasons given in the preface. Cuvier says the orders of fish are more difficult to define than the orders of any other class of animals. 
Synbranchus, (surinam-eel, body eel-form; pectoral fins none; spiracle single, beneath the neck.

SPHAGEBRanchus, body eel-form ; pectoral fins none; spiracles two, beneath the neck.

Monopterus, body eel-form ; nostrils placed between the eyes; fin caudal.

Gymnotus, (electrical-eel, head with lateral opercula ; tentacula two on the upper lip; eyes covered by the common skin; gill-membrane 5 rayed; body compressed and carinated by a fin beneath. In most species no dorsal fin.

Ophivius, (eel-fish,) head somewlat naked, teeth in the jaws and palate and throat ; branchiostegous membrane 7-rayed; patulous; body ensiform.

ODONTOGNATHUS, mouth furnished with a strong: moveable lamina or process on each side of the upper jaw; gill-membrane 5-rayed.

Comephorus, head large, with depressed snout; mouth large, with small teeth ; body elongated, compressed ; the second dorsal fin furnished with several long naked rays.

TriURUs, (tripple-tail,) snout cylindric; tooth single in each jaw ; fin, dorsal and anal, extended beyond the tail.

Ammodytes, (launce, head compressed, natrower than the hody; upper lip doubled; lower jaw narrow, pointed ; teeth small and sharp ; gillmembrane 7-rayed; body long, roundish, with very small scales; tail distinct.

Leptocephalus, (morris, head small, narrow: body very thin, compressed; pectoral fins none. Stylephorus, (thread-tail,) eyes pedunculated, standing on a short thick cylinder; snout length- 
ened, directed upwards, retractile towards the head by means of a membrane; mouth without teeth? branchiæ three pair beneath the throat; fins, pectoral small, dorsal the length of the back, cauilal short with spiny rays; body very long, compressed.

Trichiurus, (needle-tail,) head stretched forward, with lateral gill-covers; teeth ensiform and. semisagittate at the tips; gill-membrane 7-rayed; body ensiform, compressed, with subulate, finless tail.

Anarchrchas, (wolf-fish,) head rather obtuse; fore-teeth, both above and below, conical, divergent, strong, 6 or more in number; grinders in the lower jaw and palate rounded; gill-membrane 6rayed ; body roundish ; tail-fin distinct.

Xiphinas, (sword-fish,) head with the upper jaw terminating in a sword-form snout; mouth without teeth ; gill-membrane 8-rayed; body roundish, without scales.

Stromateus, (stromat,) head compressed ; teeth both in jaws and palate; borly rhombicovate, compressed, lubricous.

Stennoptrix, (amber-fish, head obtuse ; mouth abrupt ; teeth very minute; gill-membrane none; body compressed, without visible scales; breast carinate, folded both ways; abdomen pellucicl.

\section{ORDER 2. JUGULARES.}

Gill-membranes with bony rays; ventral fins before the pectoral.

Callionymus, (dragonet, eyes vertical, approximated; gill covers shut, with a small aperture on each sille the neck ; gill-membrane 6-ray. ed; body naked; ventral fins very remote. 
Uraxoscopus, (star-gazer, head large, depressed, rough ; mouth furnished with an internal cirrus; gill-covers edyed by a ciliated border; gillmembrane 5-rayed.

Tracunus, (weever, prickle-back, ) head slight ly roughened, compressed; gill-membrane 6-rayed; gill-covers serrated on the edge ; body compressed; vent situated near the breast.

GaDUs, (cod-fish, haddock,) head smooth ; gillnembrane 7-rayed; body oblong, covered with deciduous scales ; fins all covered by the common skin; dorsal and anal generally more than one; the rays unarmed; ventral fins slender, ending in a point.

Blensius, (blenny, head sloping; body length. ened ; sub-compressed, lubricous ; gill-membrane 6-rayed ; ventral fins 2, 3 or 4-rayed, unarmed.

KurTus, body bruarl, carinated both above and below; with greatly elevated back : gill-membrane 2-rayed.

\section{ORDER 3. THORACICI.}

Gill-membranes with bony rays ; ventral-fins under the pectoral.

Cepola, (band-fish, ) head short; teeth curved, sharp; body veiy long and compressed; abdomen extremely short; gill-membrane six-rayed.

Grmnetrus, body extremely long, compressed; teeth numerous, subulate; gill-membrane four or five-rayed ; anal-fin wanting.

VanDellius, (vandal, body extremely long, sword-form ; gill-membrane five or six-rayed; teeth subulate, those in front largest.

Echeseis, (remora, sucking-fish,) head fur- 
nished above with a flat, ovate, transversely sulcated shield; gill-membrane six-rayed; body without scales.

CoRyphæNa, head sloping suddenly downwards; gill-membrane five-rayed; dorsal-fin the length of the back.

Macrourus, (imminset,) head large; eyes large; body at the hind part attenuated into the tail.

GoвIus, (goby, head small ; eyes approximated ; gill-membrane four-rayed; ventral-fins united into the form of a funnel.

Gobıomorus, habit as the Gobius; with ventral-fins distinct.

Corrus, (bullhead,) head broader than the body, spiney; eyes vertecal and having a nictitating membrane; gill-membrane six-rayed. In most species the body is without scales; attenuated towards the tail, and with two dorsal-fins.

Sconpena, head large, aculeated, cirrose, obtuse, without scales, sub-compressed; eyes near each other; teeth in the jaws, palate and throat; gill-membrane seven-rayed; body fleshy; dorsal-fin single, with the rays of the forepart spiny.

ZEus, (dory, head compressed, sloping down; upper lip arched by a transverse membrane; tongue subulate (in most species); body compressed, broad, sub-rhomboid, thin, and of a bright colour; gill membrane with seven perpendicular rays, the lowest transverse; dorsal fin (in most species) having projecting filiform rays.

Pleunonectes, (flounder, holibut, sole, eyes both on the same side of the head; body compressed, one side representing the back and the other the abdomen. 
Cramodon, (sheep-head, unicorn fish,) head small; mouth also small ; teeth close set, flexile, setaceous ; gill-membrane $3,4,5$ or 6 -rayed; bo: dy broad, coinpressed, generally banded ; dorsal and anal fin thick, fleshy and scaly at the base.

Acanthurus, teeth small, lobate (in most species); tril aculeate on each side; habit and gen. cral appearance as the Chrtodon.

Eques, (kniglit-fishy) teeth in several rows; body banded.

Trichopus, body compressed; ventral fins with an extremely long filament.

Scarus, jaws bony, divided in the middle, crenated on the edge ; teeth comnate and conglom. erate.

Sparus, teeth strong; front teeth in a single row, in some species, in 2,3 or 4 rows in others grinders (in most species) convex, smooth, disposed in ranges, so as to form a kind of pavement; lips thick; gill-covers unarmed, smooth, scaly.

Gomphosus, jaws lengthened into a tubular snout; teeth small; those in front larger.

Labrus, (old-wife,) teeth strong and subacute; griuders sometimes as in Sparus, convex. and crowded; lips thick and doubled; rays of the dorsal-fin, in some species, elongated into soft processes ; gill-covers unarmed and scaly.

Ophicephalus, head coated with dissimilar scales; body elongated.

LoNchurus, head scaly; ventral-fins separate: tail lanceolate.

Screna, head scaly; dorsal-fins two, seated in a furrow, into which they may occasionally with. draw; gill-membrane six-rayed.

Perca, (perch, basse, ruffe, teeth sharp; gill 
covers three-leaved, scaly, serrated ; dorsal-fin spiny on the forepart; scales (in most species) hard and rough.

Holocentrus, habit as Perca ; gill-covers sca$1 y$, serrated and aculeated; scales hard and rough.

Bodranus, (bodian, habit as Perca ; gill-covers scaly, not serrated, aculeated; scales smooth.

Scomber, (mackrel,) body oblong, smooth, sometimes carinated by the lateral line ; finlets (in most species) above and below towards the tail.

Gasterosteus, (stickleback, body somewhat lengthened ; dorsal-spines distinct; ventral fins spiny; abdomen carinated or shielded on the sides, and bony beneath.

Mullus, (surmullet,) head compressed, scaly : mouth bearded ; gill-membrane three-rayed; boiy covered with large subdeciduous scales.

Trigla, (gurnard,) head large, mailed and marked by rough lines; gill-covers spiny ; gillmembrane seven-rayed; finger-form processes (in most species) near the pectoral-fins.

Trachichthys, head rounded in front; eye large; mouth wide, toothless, descending; gillmembrane furnished with eight-rays of which the four lowermost are rough on the edges; scales rough; abdomen mailed with large carinated scales.

\section{ORDER 4. ABDOMINALES.}

Gill-membranes with bony rays; ventral-fins back of the pectoral.

Coritis, (loche,) mouth bearded (in most species); eyes situated in the upper part of the head; body nearly of equal thickness from head to tail; 
scales small, deciduous ; air-bladder hard or bony.

Anableps, head subdepressed ; mouth terminal ; teeth small, on the jaws ; eyes protuberant, with double pupils ; gill-membrane six-rayed.

Amra, head bony, naked, rough, with visible sutures; teeth both in jaws and palate, close-set, sharp, numerous ; cirri or beards two, near the nostrils ; gill-membrane twelve-rayed; body scaly.

SrLurus, head large, depressed ; mouth wide, bearded by long'tentacula; body lengthened, naked ; first ray of the pectoral-fins, or of the first dorsal-fin, toothed backwards.

Platrstacus, habit as Silurus; mouth beneath, bearded with cirri ; body scaleless, depressed ; tail long, compressed.

Loricaria, habit as Silurus; body mailed.

Salmo, (salmon, trout,) head smooth, compressed; tongue cartilaginous ; teeth both in the jaws and on the tongue ; gill -membrane from four to tenrayed; body compressed, furnished at the hind part with an adipose fin.

Acanthonotus, body elongated, without dorsal-fin; spines several on the back and abdomen.

Fistularia, (tobacco-pipe, trumpet-fish,) snout cylindric; mouth terminal; body lengthened; gill-membrane seven-rayed.

Esox, (sea-pike, gar-fish, head somewhat flattened above; mouth wide; teeth sharp, in the jaws, palate and tongue; borly lengthened; dorsal and anal-fin (in most species) near the tail and opposite to each other.

Polypterus, gill-membrane single-rayed; dorsal-fins numerous. 
Elops, head smooth ; edges of the jaws and palate rough, with teeth; gill-membrane with thirty rays, and armed on the outside in the middle with five teeth.

Argentina, teeth in the jaws and tongue; gillmembrane with eight rays; vent near the tail : ventral fins many-rayed.

Atherina, head somewhat flattened over the upper jaw ; gill-membrane six-rayed ; body marked by a silver lateral stripe.

Mugit, (mullet,) lips membranaceous ; the inferior one carinated within; teeth none; at the corners of the mouth an inflected callus ; gillmembrane with six curved rays; body fleshy; scales large ; dorsal-fins two.

Exoccerus, (flying-fish,) head scaly ; jaws connected on each side; gill-membrane ten-rayed : pectoral-fins very large, giving the power of flying.

Polynemus, head compressed, covered with scales; snout very obtuse and prominent; gillmenbrane five or seven-rayed; separate filaments or setaceous processes near the base of the pectoral-fins.

Clupes, (herring, shad, sprat, side-plates of the upper mandible serrated ; gill-membrane eightrayed; gills internally setaceous; abdomen sharp, and serrated generally.

Cyprinus, (carp, tench, bream, mouth small and toathless; teeth in the throat; gill-membrane three-rayed ; ventral-fins, in general, nine-rayed.

Mormyrus, snout produced ; mouth terminal ; teeth several, emarginated; aperture without gillcover; gill-membrane single-rayed; boily scaly. 
Class IV. ORDER V.

\section{ORDER 5. BRANCHIOSTEGUS.}

Skeleton cartilaginous, without ribs ; gill-membranes, with or without gill-covers.

Lormus, (angler,) head depressed ; teeth numerous, sharp ; tongue armed with teeth ; pectoral fins brachiated; no gill covers.

Cyclopterus, (sucker, head obtuse ; teeth in the jaws; tongue short and thick; body thick without scales; ventral fins united into a circle.

Balistes, (file-fish, teeth several in both jaws; body compresseil; abdomen cariuated; skin tough, often reticulated by scale-like divisions; no gill-covers.

Ostracron, (trunk-fish,) teeth pointing forward, cylindric, rather blunt; body mailed by a bony covering.

Dronon, jaws bony, undivided; body beset with moveable spines.

Cephalus, (mullet, sun-fish,) jaws bony ; body terminating abruptly, so that the whole fish resembles the hearl of a fish.

Tetrodon, (sun fish, \&c.) jaws bony, divided at the tip; body roughened beneath ; ventral fins wanting.

Sranathus, (pipe-fish,) snout sub-cylindric, with terminal mouth ; body lengthened, jointer, mailed; ventral fins none.

Centriscus, snout lengthened; body compress. ed, carinated beneath; ventral fins united.

Chimæra, (sea-monster, ) head pointed on the upper part, mouth placed beneath, with the upper lip five-cleft; no gill-covers; two incisors in front above and below. 


\section{ORDER 6. CHONDROPTERYGIOUS.}

Skeleton cartilaginous, without ribs.; gill-membranes wanting, with or without gill-covers.

Petromyzon, (lamprey, bedy eel-form; mouth beneath, with numerous teeth in circular rows: spiracles seven on each side the neck.

Gastrobranchus, (hag-fish,) body eel-form, mouth beneath, with numerous pectinate teeth ; spiracles two, beneath the abdomen.

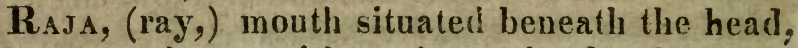
transverse, beset with teeth ; spiracles beneath, tive on each side of the neck ; lody, in most species, subrhomboidal.

S'qualus, (shark, mouth situated beneath the anterior part of the head, with numerous teeth disposed in rows; spiracles on each side the neck (in most species five,) of a semi-lunar shape; body oblong, somewhat cylindric.

Spatularia, habit as Squalus, ; spiracles single on each side the neck and concealed by a large gill-cover; snout produced, spatulate; mouth beneath the head, large and furnished with sharp serrate teeth.

Achlencer, (sturgeon, sterlet,) having gillcovers; snout bearded beneath : mouth beneath the hear, ovate, tonthless, retractile; body elongated, mailed above by tubercles.

Pegasus, having gill-covers ; snout elonged not bearded; mouth beneath ; pectoral fins large ; ventral fins single-rayed; body depressed, mailed, wilh the abdomen divided into bony segments. 


\section{$(91)$}

\section{CLASS V. ANNELIDA.}

Remarks. Animals of this class have heretofore been distributed among various divisions of the Linnean vermes ; but no naturalist was satisfied with such a distribution. These animals having red blood, and soft jointed bodies, they seemed to be excluded from all places in the system. The French naturalists have obviated this difficulty by creating a new class; and placing this class under the grand division Articulata. As these animals have no limbs for walking, it was necessary to make the definition of this division more general-referring to their jointed bodies, without specifying articulated limbs. They are all reproduced like plants with perfect flowers.

\section{ORDER 1. TUBICOLA.}

Semi-molluscous and encased in calcareous tubes.

Serpula, (shell-worm, animal a terebella : shell univalve, tubular, generally adhering to other substances; often separated internally by divisions at uncertain distances.

SABELla, (cased-worm, animal a nereis, with a ringent mouth and 2 thicker tentacula behind the head ; shell tubular, composed of particles of sand, broken shells, and regetable substances, united to a membrane by a glutinous cement.

Amphitrite, body projecting from a tube and annulate ; peduncles or feet small, numerous ; feelers 2, approximate, feathered ; eyes none. In sea and wet sand. 
Dentalium, (tooth-shell,) animal a terebella ; shell univalve, tubular, strait or slightly curved, with an undividerl cavity open at both ends.

\section{ORDER 2. DORSIBRANCHIA.}

Respiratory organs distributed along one side of the body, which may be called the back.

Nereis, body long, creeping, with numerous lateral peduncles, or feet, each side ; feelers simple, rarely none; eyes 2 , or 4 , rarely none. In sea.

Aphrodita, (aphrodite,) body creeping, oblong, covered with scales, and furnished with numerous bristly fasciculate feet, each side ; mouth terminal, cylindrical, retractile ; feelers 2 , setaccous, annulate; eyes 4 . In sea.

\section{ORDER 3. ABRANCHIA.}

Having na particular respiratory organs; but the office of respiration is performed along the whole surface of the slin.

Lumbricus, (angle-worm, earth-worm, body round, annulate, with (generally) an elevated fleshy belt near the head, mostly rough with minute concealed prickles placed longitudinally, and furnished with a lateral aperture. In common soil, wet soil, and wet rotten wood and manure.

NaIs, (glass-worin, body creeping, long, linear, pellucid, depressed; peduncles or feet with small bristles each sirie; tentacula or feelers, none; eyes two or none. In stagnant waters, rivers and wet sand. 
Hirudo, (leech, blood-sucker, body oblong, iruncate at both ends, unarmed, cartilaginous; moves by dilating head and tail and contracting: itself into an arch. In water and damp places.

Gondius, (hair-worm, hair-snake,) body round, filiform, equal, smooth. In water and damp places. 


\section{$(94)$ \\ CLASS VI. CRUSTACEA.}

Remarks. These animals were placed in the class Insecta by Lineas. There was no difficulty in this arrangement, as the characters are definite and constant. The separation is generally approbated. In truth there seems to be a wide difference between a lobster and a butterfly. But some species of the class Insecla have something of a crust, which causes many naturalists to ques. tion the beneficial uses of this subdivision.

They respire by a kind of gills or lamellar pyramids, sometimes furnished with threads. These are placed at the articulations of the body. They generally have four antennz. Their crustaceous covering is very strong in some species, as the lobster; in others it is thin and tender.

The crusts of some species have been found in the state of petrifactions or relique. But I do not think Brongniard has demonstrated the trilobite to have been of this class. I have recently found trilobites in a calciferous slate, with their carbonate of lime shells still remaining. I believe $\mathbf{M}$, Brongniard will hereafter convince himself that the trilobite was a multivalve molluscous animal,

\section{ORDER 1. DECAPODIA.}

Head confounded with the trunk.

Oancer, (crab, lobster, having ten feet; head united to the corslet, forming a shield, covering the whole anterior part of the body. 


\section{ORDERS SECOND TO FIFTH.}

Head distinct from the trunk.

Remark. These four orders of Latreille must be united, if we retain the old Linnean genera, as adopted by Shaw, according to the plan of this text-book.

Squilla, tail longer than the thorax; each mandible bears a feeler; eyes pedicelled and moveable.

Oniscus, (sow-bug,) legs fourteen; antennæe setaceous; body oval.

Monnoculus, (swimming-bug, feet formed for swimming; body covered by a crustaceous tegument; eyes, in most species, approximated and jmbedded in the shell. 


\section{$(96)$ \\ CLASS VII. ARACHNIDA.}

Remarks. Animals of this class also were placed in the class Insecta by Linneus. They are truly insects; but constituting a numerous and interesting family of a peculiar character, few object to the separation. The web of the spider attracted the notice of the earliest observers ; and it forms a subject of refference in the writings of Solomon. Were it not for that ridiculous affectation which causes the feigned screaches and screams so often heard at the approach of spiders, nothing in the whole round of natural science would be a more favorite subject of observation and study, than the instincts and structures of these beautiful and inoffensive animals.

\section{ORDER 1. PULMONARIA.}

Having hollow organs or sacks, in some measure resembling lungs, which subserve the purpose of respiration.

Aranea, (spider,) legs eight; eyes eight or six ; mouth furnished with two hooks or holders; feelers two, jointed, the tips of which, in the male, distinguish the sex; abdomen terminated by papillæ or teats, through which the threads of the web are drawn.

Sconpro, (scorpion, legs eight, besides the two frontal claspers; body ovate, elongated; eyes eight, three on each side of the thorax and two on the back; tail elongated, jointed and terminated by a curved pincer; combs (toothed processes) situated beneath, between the thorax and abdomen. 


\section{ORDER 2. TRACHENIA.}

Having no cavity resembling lungs, but respiring by a kind of trachea-like radiation of branched tubes.

Phalangium, (grey-beard,) legs eight; eyes four, two vertical and two lateral ; front furnished with cheliform antennæ; abdomen generally rounded.

Acarus, (mite,) legs eight ; eyes two, situate on each side of the head; feelers two, jointed, leg-form. 


\section{(98)}

\section{CLASS VIII. INSECTA.}

Remarks. This class comprises an immense assemblage of small animals. They are mostly of a structure which is very favorable to rapid motion. Those which have wings mostly pass through four states of existence. First the egg, second the larva, third the crysalis, fourth the winged insect. In every state they are extremely interesting.

In classifying insects, those which have wings are separated from those which have not. But still there are several species wherein the male and female differ in this particular. In general, however, insects are easily classified and described, and are very fit subjects for the exercise of the discriminating powers of the young naturalist. By studying insects and becoming acquainted with their beautiful structure, all those artificial horrors, excited by their presence, are changed into feelings of adoration for Him, who drew out their microscopic tubes, and set their respective fluids to flow in them.

\section{ORDER 1. MYRIAPODIA.}

Having any number of feet above six and no wings; head not distinct from the trunk.

JuLUs, (round centipede, antennæ moniliform ; feelers two, jointed; body subcylindric ; legs numerous, twice as many on each side as the segments of the borly.

Scolopendra, (flat centipede,) antennæe setaceous ; body depressed; legs numerous, equalling 
CLASS VIII. ORDERS II. III. \& IV.

the number of segments of the body on each side ; feelers two, setaceous.

\section{ORDER 2. THYSANOURA.}

Having but six feet, with some other organs of movement, which appear like fringes ; no wings.

Lepisma, (lepisma,) legs six, formed for running; mouth with two setaceous and two headed feelers; body imbricate with minute scales; tail furnished with extended bristles.

Podura, (spring-tail,) legs six, formed for running; eyes two, composed of eight; tail forked, formed for leaping, inflected ; antennæ setaceous, elongated.

\section{ORDER 3. PARASITA.}

Having six feet, no fringe-like organs; no wings; crawl upon other animals.

Pediculus, (louse, legs six, formed for walking; mouth furnished with an exsert piercer; antenna the length of the thorax; abdomen depressed, sublobate.

\section{ORDER 4. SUUC'TORIA.}

No wings; beak a sucker enclosed in a cylindric sheath of two articulated pieces.

Pulex, (flea,) legs six, formed for leaping; eyes two; antennæe filiform; mouth furnished with an inflated, setaceous snout, concealing a piercer, abdomen compressed. 


\section{ORDER 5. COLEOPTERA.}

Having four wings, the outer pair (called elytra) crustaceous, the inner pair folded transverse$l y$, or not extended longitudinally.

Sec. A. Tarsus with five joints; palpi six.

Cicindela, (tiger-bug,) antennæ setaceous; jaws prominent, denticulated ; eyes protuberant thorax roundish and margined.

Carabus, antenna setaceous; thorax some what heart-form, truncated in front, margined; abdomen ovate; wing-sheaths margined.

Drtiscus, (swimmer, antennæ setaceous; hind legs villose, formed for swimming and terminated by scarcely visible claws.

Hydrachna, (water witch, water-spider, legs eight, formed for swimming; head, thorax and abdomen united, or connate; feelers two, jointed ; cyes 2, 4 or 6 .

Groinus, (glimmer-cheffer,) antennse clavate, stiff, shorter than the head, eyes apparently four, two above and two below.

Sec. B. Tarsus with five joints ; palpi four: antennæ not enlarged at the ends nor luminated.

STAPHxlinus, (rove beetle, antennæ moniliform; wing-sheaths halved; wings covered; tail simple, occasionally protruding two oblong vesicles.

Buprestis, antennæ setaceous, of the length of the thorax; head half withdrawn beneath the thorax.

Elater, (snap-bug, antennæ setaceous ; body oblong, when placed on the back, springing up by 
means of the pectoral spine starting from the abdominal foramen.

Lampyris, (glow-worm,) antennæe filiform ; wing-sheaths fiexile; thorax flat, semiorbicular, concealing and surrounding the head; abdomen with the sides plaited into papillæ; female wingless (in most species.)

Cantharis, antennxe setaceous; thorax margined, shorter than the head; wing-sheaths flexile; abdomen plated into papillæ on the sides.

Prinus, (plant-thief,) antennæ filiform, with the three last joints largest; thorax roundish without distinct margin, receiving the head occasionally.

Section C. Tarsus with five joints ; palpi four ;: antennæ enlarged at the end or laminated.

Hister, antennæ headed by a somewhat solid tip, lowest joint compressed and decurved ; head. retractile ; mouth forcipated ; wing-sheaths shorter than the body; fore legs toothed.

Srlupila, (protector,) antennæ thickening to. wards the tip; wing-sheaths margined; head prominent, thorax flattish, margined.

Dermestes, (leather-chaffer, ) antennæ clavate, with perfoliate tip, the three last joints larger than the rest; thorax convex, scarcely or very slightly margined; head withdrawn at pleasure beneath the thorax.

BYRRHUs, antennæ clavate, subsolid, subcom. pressed.

Hydrophilus, (driver, ) antennæ clavate-perfoliate ; hind legs villose and formed for swim ming. 
Scarabæus, (beetle, antennæ or horns clavate, with a fissile tip; legs generally toothed; body thick and compact.

Lucasus, (ox-chaffer, antennæ clavate, with compressed tip, divided into lamellæ on the inner side; jaws stretched forward, exsert and toothed.

Sec. D. Tarsi with one more joint to each of the four forward ones, than to the two hindmost. Generally four to each forward one.

Tenebrio, antennx moniliform with the last. joint rounded; thorax planoconvex, margined ; head exsert; wing-sheath stiffish.

Diaperis, (shield-bug,) bead concealed under the corslet or received in a deep excavation in its forward end ; the sides of the corslet and of the chest project over the body. It is often very flat, oval, and in the form of a shield.

MELoe, (spanish fly,) antennæ moniliform, with the last joint ovate ; thorax roundish ; wingsheaths soft and flexile; head inflected.

Mondfla, antennæ filiform, serrated ; head bent down when disturbed ; feelers compressedclavate, obliquely truncated ; wing-sheaths curving downwards towards the tip; lamina broad, before the thighs, at the base of the abdomen.

\section{Sec. E. Tarsus always with four joints.}

Bruchus, antennæ filiform, gradually thickening; head retracted and inflected ; thorax attenuate in front; wing-shells truncated, shorter than. the abciomen.

Atriliabus, head attenuated behind ; antennzthickening towards the tip. 
Curculro, (weevil,) antennæ subclavate situated on the snout; snout horny prominent.

Pausus, antennz of 2 joints, the upper very large, inflated, moveable, and hooked; head stretched forward; wing-sheaths flexile, deflected, truncate.

MYcetophagus, body oval ; antennæ gradually enlarged, perfoliate in a great number, (they terminate in a mass of three or four articulations upon each other.) They live in mushrooms and under the bark of trees.

Cenambrx, (goat-chaffer, goat-horns, antennæ slender and gradually attenuated; thorax either spiny or bulging; wing-sheaths sublinear ; body oblong.

Leptura, (wood-beetle,) antennæ setaceous; wing-sheaths attenuated towards the tip ; thorax subcylindric.

NECYDALis, antennæ setaceous ; wing-sheaths smaller, shorter and narrower than the wings; tail simple.

HisPa, (prickly-beetle, antennæ spindle-form, approximate at the base, situate between the eyes ; thorax and wing-shells generally aculated.

Cassida, (tortoise-beetle, antennæ moniliform, thickening towards the tip; head concealed beneath the shield of the thorax ; thorax and wingsheaths dilated and margined; body oval, convex, flat beneath.

Chrysomela, antennæ moniliform, thickening towards the tip; thorax margined; body ovate of oblong, convex. 
Sec. F. Tarsus always with three or with two joints.

Coccrnella, (lady-bug, ladies'-bird,) antenna subclavate and truncate ; feelers with semicordate tips; body hemispheric, with the abdomen flat beneath.

\section{ORDER 6. ORTHOPTERA.}

Having four wings, the outer pair generally of a leathery texture; the inner pair plaited longitudinally.

Forficula, (earwig, ) antennæ setaceous ; wingsheaths halved; wings covered ; tail forcipated.

BLATTA, (cockroach,) head inflected ; antennæ. setaceous ; wings flat, subcoriaceous ; thorax flatish orbicular, margined ; feet formed for running; hornlets two over the tail.

Mantis, (soothsayer, head unsteady, armed with jaws and furnished with palpi or feelers; antennæ setaceous ; thorax linear; wings 4 , membranaceous, convolute ; the lower pair pinted ; forelegs, in most species, compressed, serrated beneath and armed with a single claw and with a setaceous, lateral, jointed foot ; hind-legs.smooth, formed for walking.

Phasma, (spectre,) head large ; antennæ filiform; eyes small, rounded stemmata 3 , between. the eyes; wings 4 , membranaceous, the upper pair abbreviated, the lower plaited ; feet formed for walking.

GryluUs, (grass-hopper, locust, ) head inflected, armed with jaws, and furnished with feelers ; antennæ in most species, either filiform or setaceous:; 
wings 4 , deflexed, convolute, lower ones plaited ; hind-legs formed for leaping; claws double on all the feet.

\section{ORDER \%. HEMIPTERA.}

Having four wings, the outer pair mostly with the upper half crustaceous and the lower half membranaceous ; inner edges generally crossing each other at an angle more or less acute.

Crmex, (bug, fruit-bug,) snout inflected ; antennæ longer than thorax; wings 4 , cross-complicate or folded crosswise, the upper pair coriaceous on the upper part; back flat with the thorax margined ; feet formed for running.

NEPA, (water-scorpion, snout inflected ; wings 4 , cross-complicate, coriaceous on the upper part ; fore-feet cheliform, (forcipated) the rest formed for walking.

Notonecra, (boat-fly,) snout inflected ; antennæ shorter than thorax; wings coriaceous on the upper part and crossed over each other; hind feet edged with hairs and formed for swimming.

CiCADA, (amaerican locust, caty-did, green-grasshopper,) snout inflected ; antennæ very short, setaceous ; wings 4, membranaceous, deflected; feet, in most species, formed for leaping.

Fulgora, (lantern-fly, head produced into an inflated hollow front; antennæ beneath the eyes, of 2 joints, the exterior larger and globose ; snout inflected ; feet formed for walking.

Chermes, (gall-bug, ) snout pectoral ; antennse longer than thorax; wings 4, deflexed; thorax gibbose ; feet formed for walking. 
Thrrps, snout inconspicuous ; antennæ the length of the thorax ; body linear ; ablomen reflexile upwards ; wings 4 , straight, long, narrow, incumbent on the back, slightly crossed.

ApHis, (plant-louse,) snout inflected ; antennæ longer than thorax; wings either 4 , upright or none; feet formed for walking; abdomen generally furnished with 2 horns or processes.

Coccus, (cochineal bug,) snout pectoral ; abdomen bristled behind; wings 2 in males, upright; in females none.

\section{ORDER 8. NEUROP'TERA.}

Having four naked membranaceous wings, finely reticulated; the inner pair as large as the outer, and sometimes larger one way.

Libellula, (dragon's needle, dragon-fly, ) mouth furnished with several jaws; antenna very short ; wings 4 , extended ; tail, in the male, forcipated.

Ephemera, (day-fiy, ephemera,) mouth without teeth or feelers; stemmata 2, very large, above the eyes ; wings upright, lower pair smaller; tail bristled.

Panorpa, (scorpion-fly,) snout horny, cylindric, with 2 feelers; stemmata 3 ; antennæ longer than thorax ; tail of the female chelated or clawed.

Myrmeleon, (lion-ant, mouth furnished with jaws; teeth 2 ; feelers 4 , elongated; stemmata none; antennx clavate, of the length of the thorax ; wings deflecter ; tail of the male furnished with a forceps consisting of $\mathbf{2}$ straitish filaments. 
Hemerobius, (gold-eye,) mouth with 2 teeth and 4 feelers; stemmata none; wings deflected, not plaited; antenna longer than the convex thorax, setaceous, stretched forwards.

Raphidia, mouth with 2 teeth; head depress. ed, horny ; feelers 4 ; stemmata 3 ; wings deflexed; antenna the length of thorax, which is cylindric, and elongated in front; tail of females furnished with a recurved lax bristle.

T'ermes, (ticking-fly:) legs 6, formed for running ; eyes 2 ; antennæ setaceous ; mouth furnished with 2 jaws.

Phryganfa, (cadow-fly,) mouth without teeth, with 4 feelers; stemmata 3 ; antennæ longer than thorax ; wings incumbent, lower pair plaited.

\section{ORDER 9. HYMENOPTERA.}

Having four naked membranaceous wings; the inner. or hindmost pair always smaller than the others.

Tenthredo, (saw-fly,) mouth with jaws, without proboscis ; wings flat, swelled or slightly inflated ; piercer consisting of 2 serrated and scarcely projecting laminæ; scutellum with 2 distant granules.

Sirex, mouth with 2 strong jaws ; feelers 2 , truncated; antennze filiform, with more than 24 joints ; piercer exserted, stiff, serrate ; abdomen sessile, pointed ; wings lanceolate and all flat.

Ichneumon, (ichneumon,) mouth with jaws, without tongue; antennz with more than 30 joints; abdomen, in most species, peduncled; piercers exsert, with a cylindric bivalve sheath. 
Cxnips, (gall-fly,) mouth with jaws, but without proboscis ; piercer or sting spiral, generally concealed.

Chrysis, (gold-wasp,) mouth with jaws, without proboscis ; antennæ filiform with the first joint lengthened the other 11 short; abdomen arched beneath, with a lateral scale on each side; vent dentated; piercer subexsert; wings flat; body gilded.

Formica, (ant,) bead large, with diffracted filiform antennæ; mouth with large jaws and 4 unequal feelers ; thorax narrowed behind and furnished with an upright scale; abdomen subglobose; neutrals apterous ; neutrals and females furuished with a concealed sting.

Mutilla, antennæ filiform ; body downy ; thorax retuse behind ; wings frequently wanting; sting concealed.

SpHEx, (solitary-wasp,) mouth with jaws, without tongue ; antennæ of 10 joints ; wings flat, incumbent, not plaited ; sting concealed.

VESPA, (wasp, hornet,) mouth with jaws, without proboscis; upper wings plaited ; sting concealed ; eyes lunated; body smooth.

ApIs, (bee,) mouth furnished with jaws and an inflected proboscis with 2 bivalve sheaths; wings flat, or without plaits ; sting concealed in the female and neutral bees.

\section{ORDER 10. LEPIDOPTERA.}

Having four membranaceous wings, generally large, covered with small scales. The scales appear like dust, when brushed off under the naked eye.

Papilio, (butterfly,) antennæe thickening to- 
wards the extremity, communly terminating in a knob or clavate tip; wings when sitting, erect and meeting upwards ; dight diurnal.

Sphinx, (hawk-miller, antenna thickest in the middle, subprismatic and attenuated at each extremity ; wings deflected ; flight strong and commonly in the morning or evening.

Phalakna, (candle-miller, moth, antenuæ setaceous, gradually lessening from the base to tip wings, when sitting, generally deflexed and bent down archwise; flight nocturnal.

\section{ORDER 11. RHIPTERA.}

Having two membranaceous wings plaited into a fan, with two small elytralike moveable bodies near their origin, at the forepart of the corslet. A very trifling order, probably will be rejected hereafter.

Xenos, two branches of antennæ have no $\mathrm{ar}^{2}$ ticulation; the abdomen is horned. Under scales of other insects.

Struors, the upper branch of the hindmost piece of the antennæ is composed of three small joints; the abiloinen is retractile and fleshy. Under scales of other insects.

\section{ORDER 12. DIPTERA.}

Having but two wings.

Culfx, (gnat, musqueto,) mouth consisting of setaceous piercers, within a flexible sheath.

Tipula, (crane-fly,) mouth arched over by the upper jaw extending from the head ; palpi 2 , recurved, longer than the head; proboscis recurved, very short. 
Asruus, (hornet-fly,) mouth with a straight, horny, bivalve snout.

EMprs, mouth with a horny, inflected, bivalve snout, longer than the thorax, with horizontal valves.

Bombylius, (humming-fly, mouth furnished with a very long porrected, setaceous, bivalve trunk; with horizontal valves including setaceous piercers.

Tabanus, (ox-fly, mouth formed into a fleshy proboscis, terminated by 2 lips; rostrum furnished with 2 pointed palpi, placed on the side of, and parallel to, the proboscis.

Conops, mouth with a porrected, jointed snout.

Oestrus, (gad-fly, ) antennæ triarticulate, very short, sunk; face broad, depressed, vesicular ; mouth a simple orifice ; feelers 2, biarticulate, sunk ; tail inflected.

Musca, (house fly,) mouth formed into a fleshy proboscis, with 2 lateral lips ; palpi none.

Dropsis, (stem-eye,) antennæ very small, setaceous, eyes situated on very long footstalks.

Happoвosca, (horse-fly,) month furnished with a bivalve, cylindric, obtuse, natant snout; body depressed ; feet furnished with several claws. 


\section{$(111 ;)$}

\section{CLASS IX. MOLLUSCA.}

Remarks. I include the whole grand division, Mollusca, in one class; though Cuvier subdivides it into the classes, Cephalopodia, head-footedPteropodia, wing-footed-Gasteropodia, trunkfooted-Acephala, headless-Brachiopodia, armfooted-Cirrhopodia, fibre-footed. As this classification is founded apon the anatomical structure of the fleshy interior of the animals, it is manifest that they cannot be classified by their shells according to this system. As our investigations are mostly confined to the shells, I have adopted the Linnean sections for orders; and prefixed an order for naked molluscous animals, which are not of the radiated division. Could we always obtain the molluscous interior, the classification of Cuvier would be preferable.

\section{ORDER 1. NUDATA.}

Soft animals destitute of shells.

Seria, (cuttle-fish,) body fleshy, receiving the breast in a sheath, with a tubular aperture at its base ; arms 8 , beset with numerous warts or suckers, and in most cases 2 peduncled tentaculæ; hearl short; eyes large; mouth resembling a parrot's beak. In sea. This is the animal called the polypus by the ancients; but that name is very differently applied by modern naturalists.

Crio, body oblong, nayant, generally sheathed, and furnished with 2 dilated membranaceous arms or wing-like processes ; tentaculæ 3 , besides 2 in the mouth. In sea. 
Doris, (sea-lemon,) body creeping, oblong; and flat beneath; muth placed below on the forepart; vent behind on the back, surrounded by a fringe ; feelers 2 to 4 , seated on the upper part of the body in front and retractile within their proper receptacle.

Triton, (water salamander,) body oblong; mouth with an involute spiral proboscis ; tentaculæ or arms twelve, six on each side, divided nearly to the base, the hind ones chelifervus.

Tetuys, body detatched, rather oblong, fleshy, without perluncles; mouth with a terminal cylindric proboscis under an expanded membrane or lip : apertures two on the left side of the neck. In sea.

Laplisia, (sea-hare,) body creeping, covered with reflected membranes, with a membranaceous shield on the back, covering the lungs ; aperture placed on the right side; vent above the extremity of the back; feelers four, resembling ears. In sea.

ŚcYlLaEA, body compressed and grooved along the back; mouth consisting of a terminal, toothless aperture ; tentacula or arms three each side, and placed beneath. In sea.

Limax, (slug, smooth snail,) body oblong, creeping;, with a fleshy kind of shield above, and a longitudinal flat dish beneath; aperture placed on the right side within the shield; feelers four, situated above the mouth, with an eye at the tip of each of the larger ones. In water, moist places, and on common soil.

Salpa, body loose, nayant, gelatinous, tubular, and open at each extremity; intestine placed ob. liquely. In sea. 
Ascids, body fixed, roundish and aparently issuing from a sheath. In sea.

DAGYSA, body loose, nayant, angular, tubular and open at each extremity. In sea.

Pterotrachea, body detached, gelatinous, with a moveable fin at the abdomen or tail ; eyes two, placed within the head. In sea.

Deir Ris, body cylindric, composed of articulations; wouth terminal; feelers two. In sea.

ONCHIDIU , body oblong, creeping, flat beneath; : mouth placed before; feelers two, situate above the mouth; armes two, at the sides of the head; vent behind, and placed beneath. On leaves.

Lobaria, body above convex, beneath flat, 10bate. In sea.

\section{ORDER 2. MULTTVALVA.}

Soft animals, having, shells with more than two. valves.

Chiton, (monoloba,) animals inhabiting the shell, adoris ; shell consisting of several segments or transverse incumbent valves, disposed in a lon. gitudinal series down the back.

LEPAS, (acorn-shell, barnacle, animal a triton; shell affixed at the base and consisting of: many unequal erect valves. Formerly called the barnacle goose-egg:

Pholas, (piddock, animal an ascidia ; principal shell bivalve divaricate, with several lesserdifferently shaped accessary ones at the hinge : : hinges recurved, united by a cartilage ; in the in side beneath the hinge is an incurved tooth. 


\section{ORDER 3. BIVALVA.}

Soft animals, having shells with two valves.

Mya, (pearl-muscle, gaper,) animal an ascidia; shell bivalve, generally gaping at one end ; hinge with broad thick strong teeth, seldom more than one, and not inserted into the opposite valve.

Solen, (razor-sheath, a nimal an ascidia; shell bivalve, oblong, open at both ends; hinge with a subulate reflected tooth, often double, and not inserted in the opposite valve.

Tellina, animal a tethys; shell bivalve, generally sloping on one side ; in the forepart of one valve a convex, of the other a concave, fold; hingo usually three teeth, the lateral ones smooth in one shell.

Cardium, (cockle,) animal a tethys ; shell bivalve, nearly equilateral, equivalve, generally convex; longitudinally ribbed, striate or grooved, with a tnathed margin; hinge with two alternate teeth near the beak in the middle, and a larger remote lateral one each side, each locking into the. opposite.

Mactra, animal a tethys ; shell bivalve, unequal sided, equivalve ; middle tooth of the hinge complicated, with a small hollow each side, lateral ones remote and inserted into each other.

Donax, animal a tethys; shell bivalve, with generally a crenulate margin, the frontal or anterior margin very obtase; hinge with two teeth, and a single marginal one placed a little behind, which is rarely double, triple or none.

Venus, (common clam,) animal a tethys; shell bivalve, the frontal margin flattened with incum. 
bent lips ; hinge with three teeth, all of them approximate, the lateral ones divergent at the tip:

Spondylus, (thorney oyster, animal a tethys; shell hard, solid, with unequal valves; one convex, the other rather flat; hinge with two recurved teeth separated by a small hollow.

Chama, (basin conk,) animal a tethys; shell bivalve, rather coarse; hinge with a callose gibbosity, obliquely inserted in an oblique hollow; anterior slope closed.

Arca, (noah's ark, animal a tethys? shell bivalve, equivalve; hinge with numerous sharp teeth alternately inserted between each other.

Ostrea, (oyster, scallop,) animal, a tethys ; shell bivalve, generally with unequal valves and. slightly eared; hinge without teeth, but furnished with an ovate hollow, and mostly lateral, transverse groove.

ANomia, (thin-shell,) animal emarginate, ciliate, strap-form, with bristles or fringe affixed to upper valve; shell bivalve, one valve flatish, the other gibbose at the base, with a produced beak generally curved over the hinge; hinge without teeth, but a lateral tooth within, on the margin of the flat valve ; two bony rays for the base of the animal.

Mrtilus, (mother pearl, muscle, animal allied to an ascidia; shell bivalve, rough, generally afixed by a byssus or beard, of silky filaments; hinge mostly without teeth, with sometimes a subulate excavated longitudinal line.

Prnna, (wing-clam,) animal a limax; shell sub-bivalve, fragile, upright, gaping at one end, and furnished with a bissus or beard; hinge with- 
out teeth, the valves united into one. Nacre; yielding byssus of which silk is sometimes made.

\section{ORDER 4. UNIVALVA.}

Soft animals, having shells with single valves.

Argonauta, (paper nautilus, animal a sepia or clio ; shell univalve, spiral, involute, membranaceous, one-celled.

Nautilus, (pearl nautilus,) animal sepia ; shell univalve, divided into several departments communicating with each other by an aperture or siphunculus.

Conus, (cone, animal limax; shell univalve, convolute, turbinate ; aperture efiuse, longitudinal, linear, without teeth, entire at the base; pillar smooth.

Crpraea, (gourie, sea-porcelain,) amimal a li$\max$; shell univalve, involute, subovate, smooth, obtuse at each end; aperture effuse at each end, linear, extending the whole length of the shell, and toothed each side.

Bulla, (dipper-shell,) animal a limax; shell univalve, convolute, unarmed with teeth; aperture a little straitened, oblong, longitudinal, very entire at the base ; pillar-lip oblique, smooth.

Voluta, (mitre, volute, animal limax ; shell one-celled spiral ; aperture without a beak, and somewhat effuse ; pillar twisted or plaited, generally without lips or perforations.

Buccinum, (whelk, belmet-shell,) animal li$\max$; shell univalve, spiral, gibbose; aperture ovate, terminating in a short canal leanin to the right, with a retuse beak or projection ; pillar-lip: expanded. 
Strombus, (dinner-horn,) animal a limax ; shell univalve, spiral; the lip of the aperture often much dilated; expanding, and produced into a groove leaning to the left.

Murex, (thorn-shell,) animal limax ; shell inequivalve, spiral, rough, with membranaceous sutures ; aperture oval, ending in an entire, straight or slightly ascending canal.

Trochus, (top-shell, animal limax ; shell univalve, spiral, more or less conic ; aperture somewhat angular or rounded, the upper side transverse and contracted ; pillar placed obliquely.

Turbu, (periwinkle, stair-case,) animal limax; shell univalve, spiral, solid ; aperture contracted, orbicular, entire.

HeLix, (snail, animal limax ; shell univalve, spiral, subdiaphanous, brittle ; aperture contracted, semilunar or roundish. In dry and wet soil and water.

Nerita, (sea-snail,) animal limax ; shell univalve, spiral, gibbose, flattish at bottom ; aperture semiorbicular or semilunar ; pillar-lip transversely truncate, flatish.

Halyotis, (sea-ear,) animal limax ; shell univalve, dilated, ear-form, with a longitudinal row of orifices along the surface; spire lateral and nearly concealed.

Patella, (limpet,) animal limax ; shell univalve, subconic, shaped like a basin; without spire.

Teredo, (ship-worm,) animal a terebella, with two calcareons hemispherical valves cut off before, and two lanceolate ones; shell iapering, flextose and capable of penetrating wood. 


\section{( 118$)$ \\ CLASS X. ECHINODERMA.}

Remarks. The organic structure of the animals of this class is more complicated than that of any other class of this division. They have an organized covering, often sustained upon something resembling a skeleton, which supports sharp processes or spines sometimes moveable. They have an imperfect vascular system, and their respiratory organs are often very distinct. Some species have fibres, which seem to supply the office of nerves.

\section{ORDER 1. PEDICELLATA.}

Having stem-like moveable processes which per form the office of feet.

Asterias, (sea-star, body depressed, covered with a coriaceous crust, muricate with tentacula, and grooved beneath; mouth central, five-rayed. In sea.

Encrinus, (stone-lily,) a stem divided into numerous articulations; its branches are like the stem, and subdivided dichotomousiy. Its fossil remains have been called entrochites, which are pieces of the stems and branches of this genus.

Echinus, (sea-urchin, sea-hedghog,) body roundish, covered with a bony sutured crust, and generally furnished with moveable spines; mouth placed beneath, and mostly five-valved. In sea.

Holothuria, body detached, cylindric, thick, naked, and open at the extremity ; mouth surrounded by fleshy branches, tentacula or feelers. In sea. 


\section{ORDER 2. APODA.}

\section{Having no organs for locomotion.}

Sipunculus, (tube-worm, ) body round, elon gated; mouth cylindric at the end, and narrower than the body; aperture at the side of the body and veruciform. In the sea under stones. 


\section{$(120)$ \\ CLASS XI. INTES'IINA.}

Remarks. This class does not include those animals which enter the bodies of other animals in maturity. It includes those only which reside and propagate in the alimentary canals, glands, cellular membranes and parenchymous coverings of other animals. As they have no respiratory organs, it is evident that the influence of oxygen, necessary to animal life, is, in some unexplained manner, transmitted to them through the animals which they inhabit. Their deficiency in respiratory organs and in uerves, induce many naturalists to consider them as morbid excrescences, not entitled to the rank of animals.

\section{ORDER 1. CAVITORIA.}

Having internal cavities for the reception of food, and mouths.

Filaria, (negro-eater,) body round, filiform, equal and quite smooth; mouth dilated with a roundish concave lip. In negro's feet.

Trichockphalus, (hair-head,) body round, elastic, and variously twisted ; head or forepart much thicker and furnished with a slender exsertile proboscis ; tail or lower part long, capillary, and tapering to a point. In men, horses, \&c.

Cucullanus, (hooded worm, body sharp, pointed behind, and obtuse before; mouth orbicular with a straight hood. In moles, buzzards, frogs, fish.

Ascaris, (spindle-worm,) body round, elastic, and tapering towards each extremity; head with 
three resicles ; tail obtuse or subulate; intestines spiral, milk-white and pellucid. In man, beast, fish; birds.

Strongylus, (horse glassworm,) body round, long, pellucid, glabrous ; the fore part globular, truncate, with a circular aperture, fringed at the margin; the hind part of the female entire and. pointed; in the male dilated into loose, distant, pellucid membranes. In horses and sheep.

LERnaEA, (fish-eater, body oblong, somewhat cylindrical, naked; tentacula or armes two or three each side and round, by which it affixes itself; ovaries two, projecting like tails from the lower extremity. In mouths, gills and fins of fish.

\section{ORDER 2. PARENCHYMATA.}

Having no particular cavities for the reception of food and no mouths, but imbibe their food by pores, which seem to mix immediately with the general parenchymous mass, constituting their bodies.

Echynorynchus, body round ; proboscis cylindric-retractile, and crowned with hooked. prickles. In hogs, birds, reptiles and fishes.

Faciola, (ground worm, fluke,) body flatish, with an aperture or pore at the head, and generally another at a distance beneath, seldom a single one. In man and all animals.

Caryophyllaus; (pink fish-eater, body round; mouth dilated and fringed. In fresh water fish.

Planaria, (eyed-worm, body gelatinous, flatish, with a double ventral pore; mouth terminal. In rivers and stagnant waters. It is divided into the no-eyed, the one-eyed, the two-eyed, the three-eyed, the four-eyed, and the many-eyed. 
TæNIA, (tape-worm,) body flat and composed of numerous articulations ; head with four orifices for suction, a little below the mouth; mouth terminal, continued by a short tube into two ventral canals, and yenerally crowned with a double series of retractile hooks or holders. In man and most mammalia, birds, reptiles and fish.

Furia, (cattle-pest,) body linear, equal, filiform and ciliate each side with a single row of reflected prickles pressed close to the body. In the skin of man and horse in Finland.

Scouex, body gelatinous, variously shaped, broadish on the forepart, and pointed behind; sometimes linear and long, sometimes wrinkled and short, round, flexuose or depressed; head protrusile and retractile. In fish.

Ligula, body linear, equal, long; the fore part obtuse, the hind part acute, with an impressed dorsal suture. In merganser and fish. 


\section{$(123)$ \\ CLASS XII. ACALEPHA.}

Remarks. These animals are often called seanettles; because it is said that a stinging sensation is often excited while handling them. They are the largest of the zoophytes. If there is such an animal as that described by seamen, under the name of kraken, it probably belongs to this class; though some suppose it may be a species of the sepia, of the class Mollusca, order Nudata. The bodies of animals of this class are suft, fleshy or gelatinons. In some we perceive something of a fibrous structure; others appear to be mere gelatinous masses.

\section{ORDER 1. AFFIXA.}

Having the habit and power of attaching themselves by their bases to resting places.

Actinia, (sea-anemone, sea-dasie, body oblong, cylindrical, fleshy, contractile, fixed by the base; mouth terminal, expansile, surrounded with numerous cirri, and without any other aperture. In sea.

IUUCERnaria, body gelatinous, wrinkled, branched ; mouth placed beneath.

\section{ORDER 2. LIBERATA.}

Never fixing themselves to a resting place, but floating or swimming upon water, by the specific levity of particular parts, or by air-bubbles contained in them. 
Medusa, (sea-nettle, sea-blubber, body gelatinous, orbicular, and generally flat underneath ; mouth central, beneath. In sea.

Physsophora, body gelatinous, pendant from an aerial vesicle, with gelatinous sessile members at the sides, and numerous tentacula beneatl. In sea. 


\section{$(125)$ \\ CLASS XIII. POLYPI.}

Remarks. Animals of this class are called poIypi, because the tentacula which surround their mouths, resemble, in some degree, those of the sepia, which the ancients called polypus. They are always cylindric, terete or conic; but the number and form of their tentacula are very variable.There is a cavity in all to receive food; but it is often a mere simple cavity or caliber. All animals of this class are capable of becoming compound ; and by cutting them in a direction to separate an individual, the cutting will live, like an inocculated bud. But their species are reproduced. by eggs.

\section{ORDER 1. NUDATA.}

Having no hard covering, and not producing a woody, horny or fleshy axis by combination.

HxDra, (sprouting polypus, animal fixing itself liy the base, linear, gelatinous, naked, contractile and furnished with setaceous tentacula or feelers ; inhabiting fresh waters, and producing its deciduous offspring, buds or eggs, from the sides.

Pedicellaria, (stiff-stem, body soft and seated on a rigid fixed peduncle; aperture single. In sea.

\section{ORDER 2. POLYPETRA.}

Having stony cases, made chiefly of carbonate of lime. This order embraces all the animals inhab. iting coral rocks. 
Sec. A. Inhabiting tubes, like the pith of a vegetable caulis; open at the summit or side.

Tubipora, (pipe-coral,) coral consisting of erect hollow cylindric parallel aggregate tubes.

Tubularia, (coral-tube, stem tubular, simple. or branched, fixed by the base ; animal projecting from the end of the tube, and having its head crested with tentacula.

Sertularia, (sea-moss, coral-grass,) animal growing in the form of a plant; stem branched, producing polypes from cup form denticles or minute cells.

Sec. B. Each polypus occupies a cell, separated from the cells of other polypi by their partitions ; and they communicate with each other by very minute pores.

Cellularia, (outer-celled coral, cells disposed in a manner to form branching stems, but without a communicating tube along the axis ; calcareous.

Flustra, (sea-mat, horn-wrack, animal a polypus proceeding from porous cells ; stem fixed, foliaceous, membranaceous, consisting of numerous rows of cells, united together and woven like a mat.

Cellepora, (inner-celled coral,) presents a mass of little cells, or calcareous vesicnles, distributed opposite to each other, pierced with a small hole.

Corallina, (coralline), animal growing in the form of a plant; stem.fixed, with calcareous subdivided branches, mostly jointed. 
Sec. C. The polypi are united in the form of a dense bark, around an axis, variable in form and in texture.

Antipathos, (sea-fan,) animal growing in the form of a plant; stem expanded at the base, internally horny and beset with small spines, externally covered with a gelatinuus flesh, beset with numerous polypi bearing tubercles.

Gorgonia, (gorgon,) animals growing in the form of a plant; stem coriaceous, corky, woody, horny or bony, composed of glassy fibres, or like stone, striate, tapering, dilated at the base, covered with a vascular or cellular flesh, or bark, and becoming spongy and friable when dry ; mouths or florets covering the surface of the stem, and polypi-bearing.

IsIs, (bush-coral,) animal growing much in the form of a plant; stem stony, jointed, the joints longitudinally striate, united by spongy or horny junctures, and covered by a soft porous cellular flesh, or bark ; mouths beset with oviparous polypes.

Sec. D. Having the stony or coriaceous covering branched, rounded, or in plates; alvays furnished with stellated laminz. In the living state, the stony part is entirely covered with a living membrane, which is soft and gelatinous, bristled with tentacula, which are the polypi.

Madrepora, (star-coral, madrepore, animal resembling a medusa; coral with lamellate starform cavities.

Pennatula, (sea-feather, sea-pen,) animal not affixed, of various shapes, supported by a bony 
part within, naked at the base, the upper part with generally lateral ramifications furnished with rows of tubular denticles, producing radiated polypes from each tube.

Alcronium, (mushroom-coral, animal general$1 y$ growing in the form of a plant, stem fixed, fleshy, gelatinous, spongy or coriaceous, beset with polypi bearing stellate cells.

Spongia, (sponge,) animal fixed, flexile, torpid, of various forms, composed either of reticulate fibres, or masses of small spines, interwoven together, and clothed with a gelatinous flesh, full of small mouths on its surface, by which it absorbs. and rejects water. 


\section{( $129 \quad)$}

\section{CLASS XIV. INFUSORIA.}

Remarks. Cuvier says, it is customary to place; at the end of the animal kingdom, those minute beings, which escape the natural eye, and which were never distinguished, until after the microscope had developed a kind of new world. They generally present gelatinous bodies extremely simple. These may be arranged together with propriety. But many animals are placed here, mereIy on account of their minuteness. Those of this description will probably be removed from this class, after farther investigation.

Infusory animals are best examined under the solar-microscope. To prepare them; steep in cold rain water almost any vegetable, for several hours; then expose this infusion for a day or twe to the sun's rays, in a situation to bring the temperature to that of common river water in the summer months. If a drop of this is put upon a piece of glass, or between two pieces, placed in the focus behind the lens of a solar microscope, the animalcula will soon appear on the screen.

\section{ORDER 1. ROTIFERA.}

Bodies oval, gelatinous ; having mouths, stomachs and intestines; often having a kind of tail, and two prominences upon the neck appear to bear eyes, and organs are seon which appear to be. concerned in respiration.

Vorticella, (whirler, body contractile, naked, and furnished with ciliate, rotatory organs. In. all waters. 
Braxchronus, (shelled jellies,) body contractile, covered with a shell, and furrished at the head with ciliate rotatory organs. In stagnant waters.

\section{ORDER 2. HOMOGENIA.}

Bodies of various forms, having neither mouth, stomach, nor any other viscera. Some have appendages resembling cilia, some appear like mere points, some are globular and more rapidly with. out any apparent organs of motion, some change their forms every moment.

Trichoda, (hair-head,) worm invisible, pellucid, hairy, or horned. In all waters.

Cercaria, (green scum,) worm invisible to the naked eye, pellucid and furnished with a tail. These insects constitute the green pellicle on stagnant waters.

Leucophis, worm invisible to the naked eye, every where ciliate. In clear marshy water.

VIBrio, worms invisible to the naked eye, very simple, round, elongated. In common water and in vegetable infusions.

Gonium, worm very simple, flat, angular, invisible to the naked eye. In pure and stagnant waters.

Colpoda, (flat-jellies, worm invisible to the naked eye, very simple, pellucid, flat, sinuate. In pure water, and infusions.

Paramecium, (oblong jellies, worm invisible to the naked eye, simple, pellucid, flattened, oblong. In salt and fresh water and among weeds.

Cyclindum, (oval jellies,) worm invisible to the naked eye, very simple, pellucid, flat, orbicular 
or oval. In infusions of hay and of some other vegetables.

BURSARIA, worm very simple, membranaceous, hollow. In marshes.

Enchelis, worm invisible to the naked eye, very simple, cylindrical. In water long kept.

Bacillaria, (straw-thread,) body consisting of cylindrical straw like filaments, placed parallel to each other, and frequently changing their position. In the ulva latissima.

Monas, (jelly-points,) worms invisible to the naked eye, most simple, pellucid, resembling a point. Smallest of all animalcula yet discovered. In sea-water long kept, in fetid infusions of pears, in most animal and vegetable infusions, and in clear pure water.

Vouvox, (globe jellies,) worm invisible to the naked eye, simple, pellucid, spherical. In com. mon water and in vegetable infusions. 


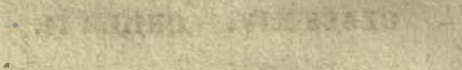

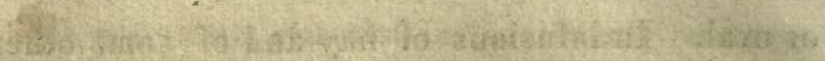

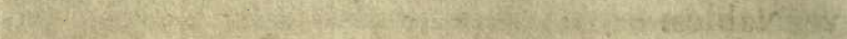

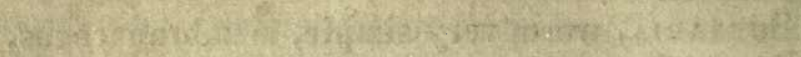
Don: 1

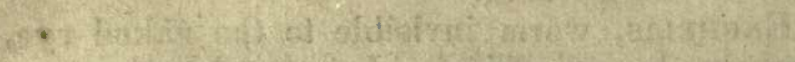

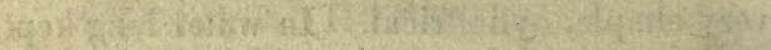

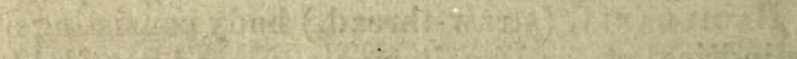

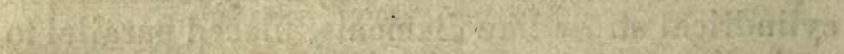

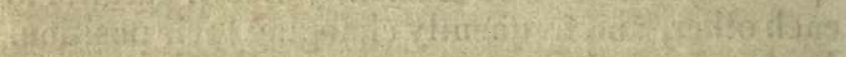

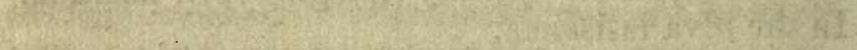

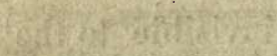
4. 28.

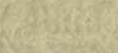

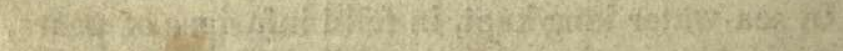
3)

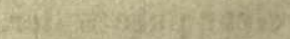

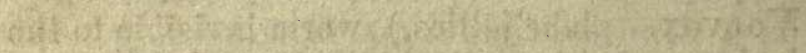

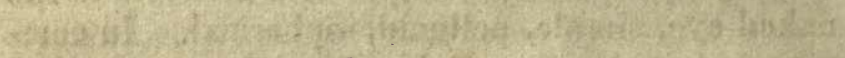

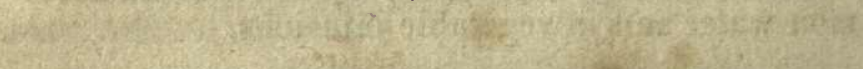

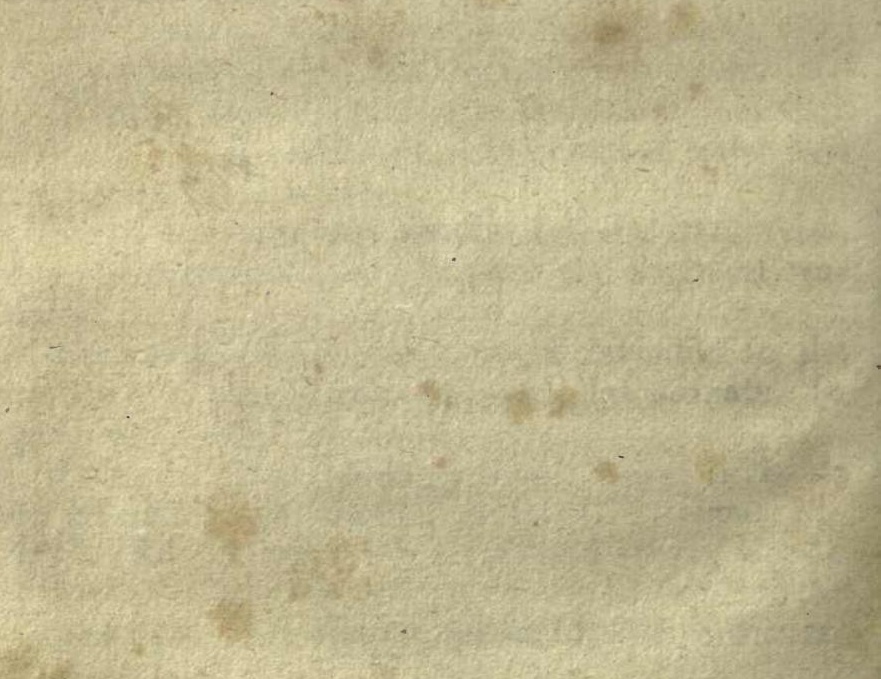




\section{ZOOLOGICAI SPICIES}

PLACED UNDER AN ALPHABETICAL ARRANGEMENT OF THE GENERIC NAMES.

Directions. After having found the generic name of an animal in the foregoing system of genera, find the same name here by seeking its alphabetical place. The numbers of the class and order stand at the left of the name, and the number of species contained in the genus at the right. The description of one species will be found under each genus, and in some cases, a considerable number.

If the specimen under examination is not described (and not one twentieth of all known species are described in this text-book) find the same genus in Rees Cyclopædia, Turtun's Linneus, Shaw's Zoology, or in whatever system comes first to hand. There look out the species. Write the name, and copy the specific character into the blank leaves, which should be bound up with this text-book at the end. Having paged the blank leaves, make a reference to the page wherein the species is copied, immediately under the printed description of the last species. By this method the student will have a description of his collection, arranged in a manner to be as accessible as if it were all in print.

By pursuing this course a few seasons, each student will be able to contribute considerably towards a system of American Zoology. At present but a small proportion of American animals, excepting those of a large size, have been sought out. Insects, in particular, are but little known. And though Mr. Say is doing much; 
without assistance, his life must be protracted to a very advanced period to afford him time to complete the work. But if every student will contribute his mite, by sending Mr. Say duplirates of all undiscribed species, we shall probably be in possession of a system, very nearly complete, in a few years.

In writing descriptions, be particular to set down the day of the month when collected, in what particular situation found, and every thing known of the habits and instincts. Such as under stones, under bark of trees, in stagnant water, in running water, under the skin of animals, making a vertical web, digging holes in the earth, catching insects, \&c. \&c.

Though but few species are described in this book, they will be found sufficient for a course of exercises. All the known species in some genera, such as Aranea, \&c. which are always accessible in every season of the year, and all the varieties of some species, such as canis familiaris, are described, for the purpose of exercising students in the varions kinds of analysis.

The following exercise is proposed for all students in Zoology, until a system of American Zoology shall be published, embracing all the species.

After finding the generic name, and searching for the specific name without success, for want of a system containing a description; give the specimen a specific name, derived from Latin or Greek, expressive of its most striking peculiarity. To this name annex a full description ; leaving out all that is contained in the generic description. This name is to be changed to that which has been given by other naturalists, whenever it is ascertained. 
By this exercise the student will acquire the habit of accurate investigation, and will become as well acquainted with the science, as if he set down the right name at first. If we know a man by a wrong name for some time; the memory is not at all embarrassed with the wrong name, after we are enabled to substitute the right one. Much pleasure and profit will be derived from a comparison of our own descriptions with those we may afterwards find in systematic works; and we learn the application of teruns by this method better than by any other in use.

\section{A. \\ 4-3. Aqutyuls. Spec. 1.}

spinus, (barley-bird,) head black, neck and back green, breast and throat greenish-yellow, belly white, tail yellow beneath. Small. Fringilla spinus of Lin.

See MS. $P$.

7-2. Acarus. Spec. about 100.

americanus, (tick, obovate, ruddy, scutella and joints of the legs white. A small insect on cattle and horses.

aphidioides, (red mite,) fore legs long; abdomen terminating in two horns; colour red. Small.

In decaying wood.

ricinus, (dog-tick.) globe-ovate, livid, a round brown spot at the base.

siro, (cheese-mite, whitish ; head and thighs rustcolour ; abdomen bristly. scabiei, (itch-mite,) white ; legs reddish ; 4 hind ones with a long bristle. 
telaris, (common mite, greenish-yellow, with a brown spot on each side of the abdomen. Small.

On hothouse and other sheltered plants. destructor, (museum-thief,) ovate; tail with long: bristles; feet with one each. See MS. P.

4-6. Acipencer. Spec. 5.

sturio, (sturgeon, nose obtuse, having four cirri near the tip; nostrils near the eyes, eyes small; mouth beneath, some distance back of the end of the nose, its length and breadth equal ; body elongated, pentagonal, flat beneath, covered above with rows of bony tubercles. suthenus, (sterlet,) nose strait, subulate, lips entire, cirri near the mouth. Nose four times as long as the diameter of the mouth. stellatus, (koster, nose spatulate, somewhat recurved ; cirri near the mouth, lips entire. Nose six times as long as the transverse diameter of the moutl.

See MS. $P$.

3-3. Acrochordus. Spec. 1.

javensis, (warted or granulated snake,) back black. belly whitish with black spots ; teeth in double rows.

See MS. P.

12-1. Actina. Śpec. 23.

bellis, (sea-daisie,) body warty ; head resembling the calyx of a flower ; tentacula retractile, variegated.

calendula, (sea-marigold,) stem subturbinate ; disk surrounded by petal-form tentacula or rays.

See MS, $P$. 


\section{2-2. Alauda. Spec. 33.}

crvensis, (sky-lark, two outermost quills of the tail white lengthwise externally, the intermediate ones ferruginous on the inside. Males are browner, with black collars, and sing.

pratensis, (tit-lark, colour above is greenish-

brown; two outermost tail-quills white externally; has a white line on the eye-brows.Slender. Bill black.

campestris, (meadow-lark,) tail-quills brown, lower half, except two intermediate quills, white; throat and breast yellow.

alpestris, (shore-lark, tail-quills half-white on the inside; throat yellow ; black stripe under the eyes and on the breast.

gubra, (red-lark,) neck, breast and lower parts redish; space about the eyes black; two outermost tail-quills white.

see MS. $P$.

\section{2-6. Alca. Spec. 12.}

torda, (razor-bill awk, four, furrows on the bill ; a white line on each side from the bill to the eyes. See MS. $P$.

2-2. Alcedo. Spec. 41.

cristata, (crested king-fisher,) tail short; sky-blue above, redish beneath; crest undulated with black. Bluish streak on the neck, beginning near the eyes. Five inches long. ispida, (common king-fisher, tail short; sky-blue above, yellowish beneath, having reddish lores.

Seven inches long. See MS. $P$. 
13-2. Alcyoniuir. Spec. 28. gelatinosum, (sea-purse,) gelatinous, yellowish, irregular. agaricum, (sea-pen,) stem filiform; pileus reniform.

See MS. $\boldsymbol{P}$.

4-4. Amia. Spec. 1.

clava, (bone-head,) dorsal-fin commences between the pectoral and ventral and extends to the tail fin, on which there is a black spot.

See MS. $\boldsymbol{P}$.

4-1. Ammodytes. Spec. 1.

tobianus, (sand launce, ) silvery white with a greenish back. Nine to twelve inches long. See MS. $P$.

2-2. Ampelis. Spec. 11.

cotinga, (camelion-bird, woods-hen, ) blue, beneath violet-blue ; wings and tail black. garrulus, (chatterer,) crested ; secondary quillfeathers red-tipped.

See MS. $P$.

3-3. Ampuisbena. Spec. 2.

alba, (cross-stripe snake,) white or yellowishwhite; head short; eyes small; body-rings 223, tail 16.

fuliginosa, body-rings 200,30 on the tail ; colour variegated. See MS. $P$.

5-1. Amphitrite. Spec. 8. auricoma, (sandy-tube, having a tube formed of rounded grains of various colours. See MS. $P$. 


\section{4-4. Anableis. Spec. 1.}

tetrophthalmus, (snub-nose,) nose truncate ; body

cylindric, covered with strong scales.

See MS. $P$.

4-1. Anarrhicas. Spec.

lupus, (sea-wolf, brown, with dark coloured bands; fins mostly whitish.

See MS. $\boldsymbol{P}$.

\section{2-6. Anas. Spec. 120.}

cygnnus, (wild swan,) bill semicylindric, black ; cere yellow ; body white.

tadorna, (sheldrake, bill knobbed at the base,

front compressed; head greenish-black ; body variegated with white.

spectabilis, (grey-head duck,) bill compressed at the base, having a black feathery keel; head hoary.

nigra, (black diver,) body totally black ; bill gibbose at the base.

marila, (scaup duck,) black; shoulders wavedcinereous; belly and a spot on the wings white. anser, (common goose,) bill semicylindric; body cincreous above, pale beneath ; neck striate. In wild flocks in Asia. By domestication it becomes white, pied and variously coloured, and too thick and clumsy for flying to great distances.

bernicla, (brent-goose,) brown; head, neck and breast black ; collar white. canadensis, (wild-goose,) cinerious; head and neck black; cheeks and chin white. lencocephala, (blue-bill duck, white-head duck,) bill broad ; tail feathers rigid, pointed, channelled, middle ones longer. 
elypeata, (shoveller, ) end of the bill dilated, rounded, with an incurved nail.

clangula, (gold-eye,) varied with black and white; head tumid, violet; large white spot at each corner of the mouth.

perspicillata, (black duck, black; crown and nape white; bill with a black spot behind the nostrils.

acuta, (pin-tail,) tail pointed, long, black beneath;

hind-head each side with a white line; back cinereous, waved.

crecca, (common teal,) wing-spot green; white

line above and beneath the eyes. Wing-spot. varies to brown and black.

caroliniensis, (american teal,) waved with black and white; head and upper part of the neck. chesnut; throat spotted with black; wing-spot green ; line beneath the eyes and shoulder-arch white.

fuscescens, (brown duck,) brownish ; head and neck paler; wings cinereous, spot blue, tipped with white; tail dusky. boschas, (mallard duck; common duck, ) cinereous ; middle tail feathers of the male (or drake, recurvate; bill strait ; collar white. Size and colour varies by domestication.

obscura, (dusky duck,) brown, edged with yellow beneath; wing-spotblue, with a transverse black bar; tail wedge-form, dusky, edged with white: See MS. P.

4-1. Anguilla. Spec. 1.

vulgaris, (common eel, silver eel,) dorsal and caudal fins united. Colour often greenish above and of a silvery bue below; but its colour va. ries according to its situation.

See MS.P. 


\section{3-3. Anguis. Spec. 24.}

centralis, (slow-worm, yellowish-green, speckled with black above. Abdominal scales 127.

See MS. $P$.

\section{9-3. Anomia. Spec. 40.}

squamula, (scale-shell,) small, orbicular, entire, thin like a fish-scale. Adheres to other shells. tridentata, (paper-shell,) pellucid, yellowish, thin, with fine transverse strix, tricuspidate, with tu-

bular points.

terebratula, (stone-shell,) shell obovate, smooth, convex; one valve with two plaits, the other with three; one beak prominent and perforate. Most common of all petrifactions. See MS. $\boldsymbol{P}$.

1-6. Anoplotherium. Spec. 2, extinct. commune, (common a plothenium, fore-feet contained a small accessory toe. mediun, (aplotherium, hind-feet with two accessory toes.

See MS. P.

1-7. Antelore. Spec. 29.

leucophæa, (blue antelope,) horns annular, recurv-: ed, roundish. Siwift.

See MS. $P$.

13-2. Antipathos. Spec. 13:

flabellum, (sea-fan,) flat, spread in an oval form. Var. flava, colour yellow. Var. purpurea, colour purple. See MS. $P$.

8-7. Aphis. Spec. about 80. brassicx, (cabbage louse,) body green, covered with mealy down ; inhabitiug plants of the ge- 
nus brassica. All the species of aphis, (called plant-lice) are named by the genitive case of the generic name of the plant upon which they are found.

See MS. $P$.

\section{5-2. Aphrodita. Spec. 9.}

aculeata, (prickly slug,) prickly, oval; six or eight inches long.

See $M$ S. $P$.

8-9. Apis. Spec, about 180.

mellifica, (common lioney-bee,) dusky ; abdomen and escutcheon of the same colour; a transverse grey band, formed of down, from the base of the third and following rings.

terrestris, (earth humble-bee, dark coloured, with the hindmost extremity of the corslet, and the hase of the abdomen, yellow; the extremity of the abdomen white. Make their nests in the earth.

lapidaria, (stone-wall humble-bee, female black, with the extremity of the abdomen reddish, wings colourless; the male has the foreside of the head and the extremities of the corslet yellow. Make their nests in walls and under stones.

See AS. P.

2-6. Aptenodyta. Spec. 11.

patagonica, (penguin,) tail slate-coloured above, white beneath; a yellowish cravat on the neck. See MS. P.

$$
\text { 7-1. Aranea. Spec. } 124 .
$$

Remarks. The genus of spiders has attracted much attention of modern naturalists. The num- 
ber and various arrangement of their eyes, their remarkable instincts, and curious structure, interest every nice observer. For these and other reasons 1 insert all the species of Gmelin, according to his arrangement. As some species may be obtained at all times of the year, they afford perpetual materials for the exercise of students in natural history.

\section{A. Eyes placed : :::}

extensa, abdomen long, silvery-greenish ; legs longitudinally extended. The head, thorax, and $\operatorname{legs}$, are reddish ; the abdomen is greenish down the back; the first pair of legs very long; the third very short.

pallens, pale testaceous ; mandibles ferruginous, with black claws.

albidorsa, black and hairy ; abdomen obovate, slender, two-horned; thorax slender, compressed laterally; back of thorax and abdomen covered with white hairs; the white ridge on the abdomen interrupted. Found at Troy, N. Y.

I propose it as a new species because it is not described in Gmelin. It may be described by other authors, which I have not seen. Eaton.* lobuta, abdomen ovate, lobed, white, with double brown lines at the tip.

longimana, ferruginous ; abdomen long, cylindric-

al, brown; the fore-legs very long, third pair very short.

regia, villous, cinereous, with a yellow band on the front; the legs are spinous.

* As very few spiders have been examined and credited in this district, I have spent a few hours this day (Sept. 15, in examining those If find about the Rensselaer School lot. I insert them as a beginning. 
virescens, green, with a black cylindrical abdomen ; the fore legs very long. canciformis, abdomen globular, gibbous, with six spines round the margin. venatoria, glossy-black, with a blackish hairy abdomen.

guttata, black; abdomen rounded, and spotted with red.

latens, black ; abdomen greyish, with a black interrupted dorsal line. Small. signata, greenish ; sides of the thorax black; ab. dornen with two black lines.

mactans, abdomen ovate, black, with a scarlet dorsal line. There is a variety whose abdomen is distinguished with two pair of scarlet dots, and a tail.

cicurea, pale-red, with a cinereous ovate abdomen.

bicornis, yellowish ; the abdomen is depressed, with six impressed dots; the head is twohorned.

nigrita, black ; abdomen with two testaceous dots beneath. Middle sized.

cornuta, brown; abdomen oval, cylindrical above, yellowish-white, with four pair of impressed dots and four parallel gray lines behind. It is about the size of a man's finger; the legs are long; the thorax truncate on each side, and ending in two small horns behind.

\section{B. Eyes placed $\because \because \cdots$}

globosa, black ; abdomen globular, with crimson sides. The body is very small; the abdomen with an interrupted white band in the middle; the legs are black; the hind ones are the longest. 


\section{Eyes placed $\because \cdots$.}

horrida, abdomen nearly triangular, the tip truncate and obtuse, the four front legs are longest. Has a retrograde motion; it is of a singular form.

maxillosa, ferruginous, with a greenish abdomen; the legs are pale; the mandibles large and projecting.

smaragdula, green ; abdomen paler, with a green dorsal line at the base.

latro, thorax villous, cinereous ; abdomen acute,

black, with ferruginous spots.

viatica, brown, with a roundish fiat obtuse abdo. men ; four hind-legs very short. Small. domestica, abdomen ovate, brown, with five black and nearly contiguous, spots, the anterior ones larger.

dorsata, green ; abdomen brown on the back. testacea, testaceous ; the abdomen is subglobular, dull-greenish.

trilineata, abdomen ovate, whitish, with three

longitudinal lines of blackish dots.

impressa, black; abdomen ovate, with six impressed dots, and two yellow dots beneath. laevipes, abdomen rhomboid, depressed, and spotted with black; the legs are extended and va. riegated.

tricuspidata, greenish; abdomen white, with a reddish tail. Head, thorax, and legs, greenish; eyes, especially the latter ones, elevated.

D. Eyes placed : : :

argentata, abdomen white, and brown behind; the margin six-toothed; thorax silvery, the mar- 
gin of the abdomen is armed with three strong spines on each side.

\section{E. Eyes placed :.::}

fasciata, silvery ; abdomen with a yellowish band ; legs annulate with brown.

angulata, abdomen ovate, sides angular and acute on the forepart; the thorax has an excavated centre. Web perpendicular, colour variable. diadema, reddish-brown; abdomen gibbous, and marked with white drop-shaped spots in the form of a cross. Body varies much in colour from a darker to a lighter reddish-brown; the legs are annulated with brown.

marmorea, brown ; abrlomen ovate ; varied with white and brown. Web on the ground; the legs are yellow, annulated with brown. reticulata, abdomen globular, reticulate, above purplish, clouded with brown. cucurbitina, abdomen subglobular, yellow, with a few black dots. Web lax. cayana, abdomen globular, pale yellowish. octo-punctata, abdomen roundish, yellow, with four black raised dots on each side; tail rufous. It is thought by some writers not to belong to this division.

bi-punctata, abdomen globular, black, with two hollow dots.

riparia, abdomen ovate, black-bronze ; tail paleyellow, and two-horned.

quadrata, abdomen sub-globular, yellowish-rufous, with a white line at the base and four spots.

liturata, testaceous ; abdomen pale black, with white margin and marks. 
quadri-punctata, abdomen oblong; the back black and flat with four excavated dots.

militaris, black; with four spines, the hind ones

longer and spreading.

spinosa, back with eight spines, the two hind ones

spreading; abdomen conic beneath; body brown

triangular.

aculeata, back with six spines, the hind ones spreading.

tetracantha, abdomen globular, with four spines round the margin; head and thorax ferruginous ; abdomen with impressed dots at the base. hexacantha, abdomen transverse, with six spines round the abdomen.

fomicata, sides of the abdomen a little vaulted, with two spines, the posterior ones the longest. labarinthica, abdlomen ovate, brown, with a whitish pinnate line. Web horizontal on the ground, with a cylindric cavity. quadri-lineata, abdomen roundish, yellow, with a purplish line on each side, and four dots. Hyaline with a yellow front. redimita, abdumen oval, pale-yellow, with a crimson oval crown or ring on the back. Legs long, white, and transparent. corollata, abdomen oval, black, with a white oval ring on the back. montana, abdomen oval, white, with grey spots; thorax and legs pale; fore-legs long and extended.

sanyuinolenta, abdomen ovate and scarlet, with a longitudinal black line. nigra, abdomen ovate, and scarlet above. notata, abdomen ovate, brown, with white transrerse curved lines. 
rufipes, abdomen brown; legs rufous.

nocturna, abdomen black, with two white dots, and a white lunule at the base.

sex-punctata, abdomen oblong, with three pair of excavated dots.

palustris, thorax and abdomen with a snowy line on each side; tip of the thorax before the eyes ends in a white line.

aquatica, brown; abdomen ovate, cinereous; the back brown with two impressed dots. Dives in search of food. Jaws large, strong, black, with scarlet nails. obscura, abdomen sub-conic, dusky, with a whitish dorsal line.

scalaris, thorax testaceous; abdomen snowy on the back, with an oblong indented snowy spot at the tip.

trigutta, yellowish; abdomen black, with three white spots.

scorpiformis, black; abdomen whitish, with two black lines; fore-legs very long. Small and retrograde.

carnifex, ferruginous; abdomen grey, with a dorsal line.

Alavissima, abdomen oblong, of a fine rich yellow colour, and smooth.

bimaculata, abdomen roundish, chesnut-brown colour, with two white dots. Less than a flea. truncorum, black, with white dots on the back.

It springs to a great distance on its prey. rupestris, abdomen with a black spot, edged with red, with white in the middle. Springs on its prey.

virescens, abdomen oblong, yellow-green, with la teral white lines. 
spinipes, pale, with spinous legs. A variety has spinose legs with ferruginous joints. opilionoides, grey with very long and extremely slender legs. Web lax irregular, the threads cross each other ; gregarious. osbeckii, pale-yellow; abdomen with impressed dots in pairs, with an odd one; the fore-legs. are longer.

wilkii, varied with black and grey; legs cinereous, annulated with black; the hinder ones are shorter

speciosa, thorax grey, with two brown spots ; the abdomen is oval-oblong, with transverse black curves; beneath it is reticulated with black, with two yellow bands. A very beautiful species.

\section{F. Eyes placed .:.}

clavipes, abdomen oblong, yellow, dotted with white ; all the shanks, except the third pair, clavated and hairy. Web strong, spreading; a beautiful species.

saccata, abdomen ovate, rusty brown. Carries its bag of eggs behind it. Under stones about Troy, New-York.

fumigata, abdomen ovate, brown, with two white dots at the base.

$$
\text { G. Eyes placed : ..: }
$$

fimbriata, black; abdomen oblong, with a white line on each side.

dorsalis, black ; thorax compressed, with a whitish dorsal line; abdomen ovate, whitish at the base; the legs are livid. Found in Sept. at Troy, New. York. 
sanguinalenta, black; abdomen red, with a black dorsal line.

(upillnta, testaceous ; abdomen brown on the back, with subocellar fulvous spots.

scenica, black ; abdomen subcylindrical, with three semicircular white lines on each side. Body covered with silvery hair; legs short, hairy, black and white.

chlorolaba, black ; long black and white hairs distributed over the body and legs; abdomen ovate, with three orange or yellowish lunulate spots on the posterior part of the back; legs with yellowish bands ; mandibles bright green. Builds a kind of membranaceous cot under stones, about Troy, N. York. I propose this as a new species; because it is not in Gmelin. Eaton.

fulvate, black ; hind margin of the thorax fulvous; abdomen with three fulvous bands. pubescens, abdomen ovate, brown, with four cinereous spots, the hind ones larger. cinerea, cinereous ; abdomen brown on the back : with eight cinereous dots.

trilineatu, brown; thorax with paler margin, and

lateral dorsal line; abdomen ovate, cinereous, beneath brown.

Garantula, abdomen with triangular black spots on the back; the legs are spotted with black. Large.

\section{H. Eyes placed ${ }^{\circ}:{ }^{\circ}$}

avicularia, thorax orbicular, convex with a transverse central excavation. So enormous that its fangs are equal to the talons of a hawk; and its eyes are used as microscopes. 


\section{Eyes placed ...: ...}

gulchra, oval-oblong; thorax white, villous, abdomen and legs black, with yellow bands.Very common at Troy, New-York, in August and September. Web vertical, in concentric polygons attached to numerous rays; rebuilt daily in fair weather, or chiefly renewed.

\section{K. Eyes placed $\because:$}

goezii, black ; abdomen ovate ; front white. The abdomen is marked with two impressed dots.

$$
\text { L. Eyes placed ... .. }
$$

truncata, grey, ferruginous, slightly clouded ; thorax globular, and slightly heart-shaped; the abdomen is something triangular and marked with an obsolete longitudinal cross, (syn. angu lata.).

\section{Eyes placed : : :}

conica, abdomen ovate, obscurely conic behind, va. ried with brown and whitish, and black beneath. Common in Sept. at Troy, N. York. Web in corners, liorizontal, dense, intangled and permanent; with a cylindrical retreat.

\section{N. Eyes placed : * :}

albifrons, hairy ; borly ovate and variegated with black and chesnut brown.

$$
\text { O. Eyes placed :: : }
$$

taurus, abdomen flat, with two very long recurred spines. 
arcuata, brown; abdomen with six spines, the middle ones curved and six times as long as the body. Small.

maculata, thorax silvery; abdomen cylindrical; legs very long and black.

pilipes, brown; abdomen cylindrical with silvery

lines; legs very long and hairy. Large. myropa, greenish ; abdomen red on the back, with a few black dots; the sides are yellowish; the mandibles are tipped with black; the thorax with two darker lines; abdomen ovate, pubescent ; textorial papillæ tipped with black; legs long, pale greenish ; the fore-shanks tipt with black. A beautiful species.

longipes, black; abdomen cylindrical, brown, with six impressed dots; the legs are very long. rufipes, ferruginous ; abdomen ovate, pale cinereous ; legs rufous.

senoculata, abdomen greenish, with black dots, and a yellow line on the sides.

scopulorum, abdomen brown, with a pennate white dorsal line.

lusea, pale ; abdomen silvery, with black branched lines.

parallela, brown ; sides of the thorax and abdomen white; mandibles projecting and parallel. scrofa, hairy, brown; abdomen semi-orbicular; mandibles black, exerted, and hooked at the

tips. Size of a pigeon egg. bicoinis, abdomen two-horned. caspia, thorax sub-globular; abdomen oblong, varied with yellow and black bands. argentea, thorax orbicular, depressed, white, with two black fillets ; abdomen is ovate, lobed, sil- 
very, with two pair of dots in the middle, and four rows behind. Web perpendicular.

P. Number and position of the eyes unknown. nobillis, thorax orange, with six black spots; ab-

domen yellow, with seven black spots. calceata, hairy, grey; legs with two black spots at the tip above, beneath silky, with a green gloss. Very large.

holosericea, abdomen ovate-oblong, silky livid

brown, with two yellow tubercles beneath. spinimobilis, abdomen roundish, yellowish brown,

with four rows of blackish dots; thighs with

black movable spines.

cruentata, black, with a yellow band at the base of the abdomen ; the breast is of a deen red. sex-cuspidata, brown; back of the thorax six toothed, with a lateral fulvous spot. hirtipes, black ; feelers and legs hairy, and pale testaceous.

tribulus, head three-toothed on the forepart; $a b$ domen covered with numerous spines. elegans, black, with two white curves on the forepart of the thorax, and a white dorsal line on the abdomen.

ocellata, pale; abdomen clouded, with a black ring; the thighs are marked with three double ocellate spots.

alba, white; abdomen with five impressed dots; two-horned and depressed at the base, and globular at the tip.

See MS. $P$.

9-4. ArCA. Spec. 36.

noa, (noah's ark,) oblong, striate, tip emarginate :

beaks very remote; margin gaping.

Sce MS.P. 
1-4. Arctomys. Spec. 11.

monax, (marmot,) ears short, round; nose bluish ; tail longish, hairy ; body grey.

empetra, (canadian marmot,) ears short, round: tail hairy; body mixed grey above, orange beneath. About 11 inches long. Very gentle but hisses.

alpinus, tail short ; colour greyish-yellow, becoming ash-coloured towards the head. About the size of a rabbit, and inhabiting high mountains, near the limits of perpetual snow.

See MS. $P$.

2-5. Ardea. Spec. 8\%. Section A. Head bald.

canadensis, (brown crane,) forehead naked, papil lose; body cinereous; wings testaceous on the outside. Three feet long.

grus, (common crane,) hind-head naked, papil-

lose ; cap and quill-feathers black ; body cinereous; tail-feathers jagged. 5 feet long.

americana, (hooping crane,) crown, nape and naked temples papillose ; front, nape and primary quill-feathers black; body white. 4 feet 6 inches long.

Section B. Middle claw serrate inwardly. major, (common heron,) hind-head with long pendant crest; body cinereous; line on the neck beneath the pectoral bar black. Head of female smooth.

stellaris, (heron,) head smoothish ; borly testaceous. above with transverse spots, paler beneath with oblong brown spots.

See $M S_{\text {S. }}$. 


\section{4-4. Argentina. Spec 4.}

raralina, (argentine,) anal fin with fifteen rays.

See M.S.P.

9-4. Argunanta. Spec. 5.

ergo, (ancient nautilus,) keel or ridge of the shell slightly toothed each side.

See MS. P.

\section{1-1. Ascaris. Spec. 78.}

lumbricoides, (human lumbricus, bowel-worm,) bo. dy long, smooth, cylindrical, tapering to both ends, with three protuberances at the fore end, and a depressed band around the body. Infests the human intestines; most frequently in young persons. From four to ten inches in length. vermicularis, (thread-worm,) body filiform ; fore end with three papillz or vesicles; whole rugose, pellucid, annular; tail commences at an aperture, and is two-thirds of the whole length. The whole worm is about half an inch in length. They orivinate in the lower part of the alimentary canal ; but often extend up to the stomach and penetrate all parts adjoining the intestines. A person may have several thousands of them, and still remain for a season in tolerable health.

Remarks. Animal oil mixed with spirits of turpentine, administered in small quantities, accompanied with tonics, is the French practice in removing both species.

See MS. $P$.

$$
\text { 9-1. Ascidia. Spec. } 34 .
$$

rustica, (spirting jelly,) oblong, brownish with flesh-coloured apertures; extremities rough, middle smooth. 


\section{8-12. Asilus. Spec 48.}

estuans, (hornet-fly,) cinereous, having the three last segments of the body white.

estivus, cinereous, having three black lines on the thorax; legs dark coloured; shanks testaceous. See MS. P.

10-1. Asterias. Spec. $3 \%$. aculeata, (sea-star,) rays five; disk orbicular, covered with glabrous prickles.

aranciaca, rays somewhat depressed and prickly

along the margin ; disk broad. caput medusæe, (medusa's head,) five rays perpetually bifurcaie into numerous branches. See MS. P.

4-4. Atherina. Spec. 5.

menidia, (silver-fish,) anal fin 24-rayed; body small, pellucid, spotted.

See MS. $P$.

8-5. Attelabus. Spec. 37.

pensylvanica, black ; shells reddish, with a black band in the middle and at the tip.

See MS. P.

\section{B.}

14-1. Bacillaria. Spec.1.

paradoxa, (straw-threads,) perpetually changing its appearance, so that it might at one moment be taken for a different species from that of the preceding moment.

See MS. $P$.

\section{1-8. Balena. Spec. 8.}

mysticetus, (common whale, nostrils flexuous, on the forepart of the head; dorsal fin none. I Var. 
black. 2 Var. large spiracle. From 50 to 100 feet long. North seas.

physalus, (fin-whale, spiracles double on the middle of the forepart of the head; a soft fin at the extremity of the back. 4 feet long. Temperate zone.

boops, (pike-head whale, spiracles double on the snout; a horny protuberance at the end of the back. 46 feet long. North seas. gibbosa, (bunched whale,) back gibbose; dorsal fin none. 1 Var. one bunch on the back. 2 Var. six bunches on the back. United States coast. musculus, (round-lip whale,) spiracles double on the forehead; under jaw very broad. 78 feet long. Norwegian seas. rostrata, (beaked whale,) nose elongated to a peak; dorsal fin fat. 25 feet long. Norwegian seas. See MS. P.

4-5. Balistes. Spec. 24.

americana, (prickle-fish.) dorsal and ventral rays very low, second dorsal fin and triangular anai. one larger.

See MS. P.

8-6. Blatta. Spec. 42.

orientalis, (common cock-roach, yellowish-brown, without spots ; wing-cases abbreviated, with an oblong groove.

americana, (sugar cock-roach,) ferruginous ; shield of the thorax whitish behind. Sec MS. P.

4-2. Blenneus. Spec. 18.

phycis, (hake, nostrils subcrested; lower lip with a cirrus; back with two fins.

See MS. $P$. 
3-3. BoA. Spec. 14.

constrictor, (speckled giant-snake, plates of the belly about 240, of the tail 60 . Often 36 feet long.

See MS. $P$.

4-3. Bodianus. Spec. 15.

serranus, (sea-perch,) having prickly apercules. See MS. $P$.

8-12. Bombrlius. Spec. 9.

major, (humming-fly,) black, with thick yellowish down; wings with a broad sinuate black outer margin. Antennæ united at the base.

zequalis, body covered with cinereous hairs, with a broad equal black outer margin. Antenna united at the base.

See MS. $P$.

1-7. Bos. Spec. 9.

taurus, (ox, bison,) horns round, turning outwards from their origin ; having lax dewlaps or folded skin before the breast. Var. bison, horns bent forward; back gibbous, having a long mane.

americanus, (spanish ox, ) horns round, distant, pointing outwards ; mane long, woolly; back gibbous.

bubulus, (buffalo, horns resupinate, turned inwards, flat on the foreside.

moschatus, (musk ox, horns approaching at the base, broad, bent inward and backward ; tips bent outwards and pointed.

See MS. $P$. 
14-1. Brachloxus. Spec. 12. urceolaris, (shell-jelly,) bell-form, with the shell many-toothed at the tip and rounded at the base ; tail long, bifid at the end.

See MS. $P$.

1-5. Bradypus. Spec. 3.

tridactylus, (three-toed sloth,) feet 3 or 4 -toed. didactylus, fore feet with two toes ; tail none. pentadactylus, feet with five toes; tail short. See MS. $P$.

8-5. Bruchus. Spec. 27.

pisi, (pea-bug,) shells black, spotted with white; tail white with two black dots. Very destructive to fields of pease.

Sce MS. $P$.

2-3. Bucco. Spec. $1 \%$

tumatia, (barbet,) tawny-brown ; tawny-white beneath, spotted with black. Inhabits torrid zone, like most of the species.

Sce MS. $\boldsymbol{P}$.

9-4. Buccinium. Spec. 190.

stromboides, (conk-whelk,) shell glabrous with distinct whorls; lip prominent ; base obliquely striate; shell yellowish-brown.

See MS. $P$.

2-2. Buceros. Spec. 16.

bicornis, (hornbill,) front bony, flat, two-horned at the forepart. Size of common hen.

See MS. $P$.

9-4. Bulla. Spec. 50.

ampulla, (bubble-shell,) rounded, obtuse at one 
end; crown umbilicate. 2 or 3 inches long. In sea.

fontinalis, (river bubble-shell,) ovate, pellucid, with an obsolete spire; whorls turning from right to left; aperture ovate-oblong. One fourth of an inch long.

See MS. $P$.

2-2. Buphaga. Spec. 1.

africana, (beef-eater,) brown above; beneath and

the rump yellowish; 8 or 9 inches long. See MS. $P$.

8-5. Buprestis. Spec. 125.

rustica, (gold-bug,) shells emarginate, striate ; body bright greenish-gold colour.

See MS. P.

14-2. Bursaria. Spec. 3.

truncatella, ventricose, truncate at the top. In marsh water.

See MS. P.

8-5. Byrrhus. Spec. 13.

pitula, brown ; shells with black interrupted strix. See MS. $P$.

C.

3-3. Cecila. Spec. 2.

fentaculata, wrinkles of the body 135 ; none on the tail. 12 inches long; one-third of an inch diameter.

See .MS. P.

4-2. Callionyuus. Spec. 7 .

lyra, (dragonet, ) first ray of the first dorsal-fin as. long as the body; 12 inches long.

see MS. $P$. 


\section{1-7. Camelopardalis. Spec. 1.}

guaffa, (giraffe-camel,) whitish-tawny, with scattered rusty spots; horns short, blunt.

Sce MS. $P$.

\section{1-7. Camelus. Spec. 7.}

dromedarius, (arahiian camel,) back-bunch single ;

8 feet and a half high.

bactricanus, (bactrian camel,) back-bunches two. glama, (lama camel,) bunch on the breast; back smooth. 4 feet 6 inches high.

huanacus, (huanaco,) body hairy ; back gibbous ;

tail erect. 4 feet 3 inches high. Fatable.

arcucanus, (peru camel,) body woolly, smooth;

nose turned upward ; tail pendulous. Resembles a sheep. Eatable.

vicugna, (andes camel,) body woolly, smooth; nose flat, blunt; tail erect. Wool soft, fine and silky.

pato, (purple camel,) no bunches; body woolly; nose oblong. Wool long and coarse. See MS. P.

\section{6-1. Cancer. Spec. about 300.}

pagurus, (eatable crab,) thorax with nine obtuse

plates at each side; pincers of the hand-claw black at the tip.

pisum, (pea-crap,) thorax orbicular obtuse; tail as large as the body. Found in muscels about the size of a pea.

gammarus, (eatable lobster, ) thorax smooth ; proboscis toothed at the sides, with a double tooth at the base, on each side ; hands smooth. See MS. $P$. 


\section{2-5. Cancroma. Spec. 2.}

cochlearia, (boat-bill,) crested ; ash-colour, having: a black crown and lunule on the neck.

See MS. $P$.

\section{1-3. Canis. Spec. 21.}

familiaris, (dog, ) tail recurvate, inclining to the left.

See MS. $P$.

Tarieties, 34.

1. Shepherd dog. Ears erect; tail woolly beneath.

2. Wolf dog. Hair of the head long; ears erect; tail much curved on the rump.

3. Siberian dog. Ears erect; hair all long.

4. Iceland $\log _{\text {. }}$ Ears erect with pendulous tips; hair long, except on the snout.

5. Water log. Hair long, curled, appearing like a sheep.

6. Dwarf water dog. Hair long, curled ; around the ears it is long, hanging down.

\%. King Charles dog. If ead smallish, rounded, snout short; tail curved back.

8. Spaniel dog. Ears long, woolly, pendulous. 9. Maltese dog. Hair soft, silky, very long. 10. Lion dog. Very small; hair on the belly and tail shorter.

11. Danish dog. Ears small, sub-pendulous; snout small, acute ; legs slender.

12. False pug-dog. Ears small, sub-pendulous; nose thick, flatish.

13. Pug-dog. Nose crooking upwards ; ears pendulous; body square.

14. Bull-dog. Sides of the lips pendulous; body robust, and about the size of a wolf. 
15. Mastiff. Very large ; sides of the lips pendulous; body robust. 16. German hound. Ears pendulous; a spurious. claw on the hind feet.

17. Common hound. Ears pendulous; a spurious claw on the hind-feet, whitish, or white with spots.

18. Blood-hound. Any hound that is very sagacious in pursuit.

19. Pointer. Tail truncate, spotted.

20. Barbet. Tail truucate, hair long, coarse.

21. Gaunt grey-hound. Head long; snout ro bust; ears small, sub-pendulous; legs long, stout; body long, slender.

22. Irish greyhound. Body curved ; snout narrowing ; size of a mastiff.

23. Turkish greyhound. Body curved, snout tapering; hair a little curled ; size of a mastiff. 24. Common greyhound. Body curved; snout tapering ; size of a wolf.

25. Rough greyhound. Body curved; snout tapering; hair longer, curled ; size of a wolf. 26. Italian greyhound. Body curved; snout tapering; small.

27. Naked dog. Body nearly destitute of hair ; mostly small.

28. Oriental dog. Tall, slender ; ears pendulous: hair on the tail hanging down very long.

29. Lurcher. Body narrow; legs stout; tail strong, strait ; hair short, thick-set. 30. Rough lurcher. Body narrow; legs stout; tail thick, strait; hair long, rough.

31. Bear lurcher. Head and snout thick; body narrow behind; feet long; hair long, rough. 
32. 'Turnspit. Legs short; body long, often spot* ted. The feet are strait or curved ; hair varies in length, and is strait or curled.

33. Alco dog. Head small; ears pendulous; back curved ; tail short; size of a maltese dog: It is sometimes very fat, neck short, belly large. 34. New-Holland dog. Tail bushy, pendulous ; ears short, erect ; snout pointed.

Remarks. These are all the distinct varieties recognized by Linneus, his editors and translator. These, however, are variously intermixed; so that it is impossible ever to give a catalogue of all the intermediate shades of character among dogs. I insert these varieties as a specimen of the effects of demestication, for the instruction of students in Natural History.

lupus, (wolf,) tail bent in wards, bushy, pendulous, black at the tip. Nose pointed, ears erect, sharp, head and neck cinereous ; body palebrown, tinged with yellow. Colour of the hair differs in different countries. In France yellow; in Russia white, in Canada and Northern states often dark brown, at the Cape of Good Hope grey and striped.

aureus, (jackal,) tail strait, body pale tawny ; ears short, erect, pointed ; tail tapering both ways, tipped with black.

lycaon, (black fox, tail strait; body black ; hairs often silvery at the tip. zulpes, (common fox.) tail strait, tipped with white; body tawny ; lips white. virginianus, (grey fox,) tail strait ; body whitishash.

crucigera, (crossed fox,) tawny ; a black cross on the shoulders; fur thick, soft. 
eustralis, (australis, tail bushy, hanging down, tip. ped with white; ears short, erect, pointed. See MS. $\boldsymbol{P}$.

8-5. Cantharis. Spec. 100.

livida, body entirely testaceous. See MS. $P$.

\section{1-7. Capra. Spec. 3.}

aegagrus, (goat,) horns keeled, arched backward s throat bearded. Variety, domestica, horn with an outward curvature at the end. V. angora, hair long, soft, silky. V.syriaca, horns reclined, ears pendulous; chin bearded. V. africana, horns short, depressed, reclining on the skull. V. whidazia, horns erect, turns forward at the ends. V. capricorna, horns short, turned forward at the tips, annulate at the sides. caucasica, (caucasian goat,) horns turned backward and outward, verging inwards at the tips, slightly triangular, knotty behind.

See MS. $P$.

\section{2-2. Caprimulgus. Spec. 19.}

suropceus, (night-hawk, goat-sucker, ) black, varied with cinereous, brown, ferruginous and white ; beneath reddish-white with brown bands. Ten inches long.

virginianus, (whip-poor-will,) brown, transversely varied with greyish brown and somewhat cinereous ; beneath reddish white, transversely streaked; chin with a triangular white spot; area of the eyes and neck above spotted with orange. 8 inches long. Its night song is monotonous, but very agreeable to those whose childhood has been spent among them.

See MS. P. 
8-5. Carabus. Spec. 365.

cyanus, no under wing; black with a violet gloss; elytra with rough confluent dots.

See MS. $P$.

9-3. Carbium. Spec. 52.

edule, (eatable cockle, shell of an old appearance, with ahout 28 depressed ribs, and obsolete recurved scales. Shell whitish with a bluish ox yellowish cast. In sandy beach.

See MS. $P$.

11-2. Caryophylleus. Spec. 1.

piscium, (pink-worm,) body clay-colour, rounded behind, broad before. An inch long. In the intestines of fish.

See MS. $P$.

8-5. Cassida. Spec. 84.

viridis, green; body black; thorax entire.

See MS. $P$.

1-4. Castor. Spec. 2.

fiber, (beaver,) tail ovate, flat, naked ; ears short, covered with fur; hair soft, short, dusky. Two or three feet long.

huidobrius, (chilese beaver,)tail compressed, lanceolate, hairy; fore feet lobed, hind feet palmate. See MS. P.

1-4. Cavia. Spec. 7.

cobaya, (guinea-pig,) tail none; variegated with white and tawney or black; body thick, neck. short. About 12 inches long

See MS. P. 
13-2. Cellepora. Spec. 8.

pumicosa, (cellepore,) irregular, brittle, erect, with gibbous, mucronate, crowded cells.

See MS. $P$.

13-2. Cellularia. Spec. 1.

salicornia, (samphire coral,) articulations cyliu. dric, holluw within ; pitts over the whole sur. ace arranged in fives.

See .MS. $P$.

4-5. Centriscus. Śpec. 3. scolopax, (snipe-fish,) body scaly, rough ; tail strait, extended. 6 or 8 inches long.

See MS. $P$.

4-5. Cephalus. Spec. 1.

mola, (round sunfish,) unarmed, rough, compressrounded ; dorsal and anal fins connected ; spiracles oval. Var. oblongus, has moonform spiracles; body oblong.

See MS. $P$.

4-3. Crpola. Spec. 3.

tcenia, (tape-fish,) caudal fin tapering, wedgeform head very obtuse. 4 to 5 feet long.

See MS. $P$.

8-5. Cerambyx. Spec. 470.

edilis, (goat-horn,) thorax spinous, with four paleyellow dots ; elytra or shells obtuse, grey, shaded with brown; antennx very long. See MS. $P$.

14-2. Cercaria. Spec. 13. mutabilis, (cameleon scum,) changeable, red or green, cylindric ; tail pointed, somewhat bifid. See MS. $P$. 


\section{2-2. Certhia. Spec. 78.}

familiaris, (creeper,) grey, beneath white ; quillfeather brown, ten of them with a white spot. See MS. P.

\section{1-7. Cervus. Spec. 11.}

alces, (moose, elk,) horns palmate, with short beams or none ; throat carunculate ; ears long, large, upright, slouching; upper lip hanging over the mouth ; neck short, slouching, with an upright mane; tail short.

elephas, (stag,) horns branched, round, recurvate ; body tawny above, whitish beneath. tarandus, (rein-deer, ) horns branched, round, recurvate ; summits palmate. Casts its horns in

Norember. Three or four feet high ; used for drawing sledges. Brown above, white beneath. dama, (fallow-deer,) horns branched, recurved, compressed; summit palmate. Colour varies by domestication from red to white. Lives 20 years. Females hornless. virginianus, (american deer, ) horns branched, turned forward, somewhat palmate. Taller than the fallow deer, and brighter coloured. mexicanus, (mexican deer, horns three-forked at the tip, turned forward ; body tawney. capreolus, (roe,) horns branched, round, erect, summits bifid; body brown.

See MS. P.

4-3. Chrtodon. Spec. 70. alepidotus, tail bifid; dorsal spines 3 ; ventral fins none.

See MS. P. 


\section{9-3. Chama. Spec. 28.}

sigas, (giant-shell,) shell plaited, with arched scales; posterior slope gaping. The largest of all shells. The two valves including the animal is said to weigh above five hundred pounds. There is one valve of vast size now in the Alba-

ny museum.

antiquata, shell subcordate, longitudinally grooved, and transversely striate.

See MS. $P$.

2-5. Charardrius. Spec. 33.

hiaticulus, (plover, breast black ; front blackish, with a white band; crown brown; legs yellow. See MS. P.

8-7. Chermes. Spec. 33. graminis, (grass-gall,) on grasses.

Remark. All the species are named by the genetive of the generic name of the plant on which they make the gall.

See MS. $P$.

4-5. Chimaera. Spec. 2.

monstrosa, (sea-monster, ) snout with porous folds beneath.

Sce MS. P.

$$
\text { 9-2. Chiton. Spec. } 28 .
$$

iuberculatus, shell seven-valved, thickly set with short hairs. See $M S: P$.

8-9. Chrysis. Spec. 31. smaragdula, (golden-fly,) green; tail six-toothed, blue.

See MS. $P$. 
8-5. Chrysomela. Spec. 340.

tenebricosa, no under wing, oval, black ; antennze and legs violet.

See MS. $P$.

8-5. Cicindela. Spec. 60.

campestris, (tiger-insect,) greenish-gold colour ; shells with six white dots.

See MS. $P$.

8-7. Cicada. Spec. 296.

septendecim, (american locust,) black ; wing-caps whitish with a yellowish rib.

See MS P.

8-7. Crmex. Spec. 823.

lectularius, (house-bug, bed-bug;) wingless ; body ferruginous.

See MS. $P$.

9-1. Clio. Spec. 6.

pyramidata, sheath triangular, pyramidal ; mouth obliquely trurcate.

See MS. $P$.

4-4. Clupea. Spec. 15.

harengus, (herring,) body without spots ; lower jaw longer.

sprattus, (sprat, box-herring, dorsal fin 17-rayed ; belly strongly serrate. alosa, (european shad,) sides with round black spots placed longitudinally; gill-covers striate; snout bifid.

sapidissima, (american shad,) no spots on the sides; snout entire. About eighteen inches long. pseudo harengus, (american herring;) body ash- 
colour above, inclining to dull greenish-blue ; sides and belly silvery; no spots on the sides: under jaw a little longest.

See MS. $P$.

4.-4. Coвitrs. Spec. 6.

tenia, (groundling,) cirri six ; a forked spine under each eye.

heteroclita, (mudfish,) head without cirri ; dorsal and anal fins spotted with white; tail barred with black.

See MS. $P$.

8-5. Coccinella. Spec 164.

heptapunctata, (tooth-ache lady-bug,) wing-cases red with seven black dots. Said to cure the tooth-ache, by mashing it between the fingers and then applying it to the tooth.

Remarks. Tiventy-eight species of this genus are distinguished by the number of dots on the elytra or shell wings; and named by prefixing a latin numeral expressive of the number of dots, to punctata.

See MS. P.

8-7. Coccus. Spec. 46.

cacti, (cochineal,) body depressed, downy, transversely wrinkled ; abdomen purplish ; legs short, black ; antennæ subulate, a third shorter than the body. The female is the cochineal of the shops; which when ground is sold under the name carmine.

See MS. P.

14-1. Colpoda. Spec. 7.

meleagris, (turkey feather, changeable ; fore part hooked, hind part folded up. See MS. P. 
2-2. Coulus. Spec. $\%$

capensis, (coly,) exterior tail-feathers white ontside; body cinereous whitish beneath. See MS. P.

3-3. Coluber. Spec. 176.

vipera, (egyptian viper,) subferruginous, spotted with brown ; beneath whitish ; tail short, mucronate. About sixteen inches long. Supposed to be the asp of Cleopatra.

constrictor, (black snake,) shining black, body long and slender; abdominal scales 186 , caudal 92.

Remark. Most of our snakes are of this genus. See MS. P.

2-4. Columba. Spec. 82.

migratoria, (common pidǵeon,) orbits naked, sanguineous ; body cinereous ; breast rusty red. caroliniensis, (mourning dove, body reddish-cinereous, reddish beneath ; orbits blue. canadensis, (a merican turtle-dove,) body greyishbrown, whitish beneath ; primary quill-feathers yellowish at the tip ; tail feathers white at the apex. 12 or 13 inches long.

See MS. Pa

2-6. Colymbes. Spec. 25.

glacialis, (loon, speckled diver,) head and neck violaceous black ; a white interrupted band on the chin and upper part of the neck. Sometimes three feet long.

cristatus, (grebe,) fuscous, white beneath ; head rufous ; collar black ; secondary quill-feathers white. About 23 inches long.

See MS. P. 
COMEPHROUS, CORVUS.

4-1. Comerhrous. Spec. 1.

baicalensis, a soft fatty substance, above a foot in length.

See MS. P.

8-12. Conops. Spec. 22.

vesicularis, blackish; hind-head vesicular; abdomen yellow with black base. Woods. Sce Mis. P.

$$
\text { 9-4. Conus. Spec. } 83 .
$$

ammiralis, (cone shell,) shell with rough punctures at the base. This species contains about forty varieties. The variety americanus, has irregular bands, is brown, cloudy or spotted.

See MS. P.

\section{2-2. Coracias. Spec. 25.}

garrula, (roller,) blue, back red; quill-feathers black; legs short, dirty yellow.

See MS. P.

13-2. Corallina. Śpec. 38.

officinalis, (coralline,) sub-bipinnate, and usually trichotomous, with the joints of the stem subcuneate or turbinate; those of the branches round, and some of the terminal ones capitate. See MS. P.

$$
\text { 2-5. Corrika. Spec. } 1 .
$$

italica, (messinger,) bill arched, yellowish ; legs brown; head brown streaked with white. See MS. P.

2-2. Corvus. Spec. 48.

corax, (raven,) black; back bluish-black ; tail roundish. Often two feet long. 
corone, (carrion crow,) entirely black, with a violet-blue gloss; tail rounded, feathers pointed at the ends. 12 to 18 inches long.

frugilegus, (rook,) black ; front subcinereous ; tail roundish; skin about the nostrils, and base of the bill bare.

monedula, (jackdaw,) black-brown ; bind-head hoary ; front, wings, and tail, black. glandarius, (jay,) wing-coverts blue, with transverse black and white lines ; body ferruginous, inclining to vinaceous. About ten or twelve inches long.

cristatus, (blue-jay,) blue, collar black ; wingcoverts with transverse black lines. pica, (magpie,) variegated with black and white; tail wedgeform.

See MS. P.

$$
\text { 4-3. Coryphina. Spec. } 19 .
$$

psittacus, (parrot fish,) lateral lines intercepted ; fins with longitudinal coloured lines.

See MS. P.

$$
\text { 4-3. Cottus. Spec. } 10 .
$$

cataphractus, (armed bullhead,) body eight-angled, mailed ; upper jaw with two upright bifid spines ; throat with numerous cirri.

scaber, (prickly bullhead,) head and lines down the body with serrate scales; lateral line acu. leate.

scorpius, (father-lasher,) head armed with numerous large spines; upper jaw rather longer than the lower.

See MS. $\mathbf{P}$. 


\section{2-4. Cirax. Spec. 6.}

alector, (curassow,) cere yellow ; body black ; bel-

ly white.

See MS. P.

\section{3-3. Crotalus. Śpec. 6.}

horridus, (rattle snake,) plates on the belly 167 ; of the tail 23. About 5 or 6 feet long; body covered with triangular spots. Thick and clumsy.

See MS. P.

2-3. Сrotophaga. Spec. 4. major, blackish violet; featbers edged with green; quill-feathers dusky-green ; feet climbers. See MS. P.

11-1. Cucullanus. Spec. $\%$

lacustris, body rufous and truncate before. Inhabits the liver and intestines of fish.

See MS P.

2-3. Cuculus. Spec. 55.

canorus, (cuckow,) cinereous; whitish beneath, transversely streaked with brown; tail round. ed, blackish, dotted with white.

americanus, (american cuckow, tail wedge-form ; body cinereous above, white beneath; lower mandable pale yellow.

See MS. P.

8-12. Culex. Spec. 14.

pipiens, (musquetoe, cinereous, with eight brown rings; antennæ of the male, pectinate. Makes a shrill buzzing noise. The Inglish call our musquetoe the gnat. 
ciliatus, (carolina musquetoe,) black, with two yellow dorsal lines on the thorax; legs yellow. SeE MS. P.

8-5. Curculio. Spec. 754.

sigas, thorax and elitra rough; antennæ tipped with white.

See Ms. P.

\section{4-2. Crclidium. Spec. 7.}

ractians, ovate, with distinctly visible intestines.

Pellucid. In vegetable infusions.

See MS. P.

4-5. Cyclopterus. Spec. 10.

lumpus, (lump-sucker,) body made angular by rows of sharp bony tubercles.

See Ms. P.

8-9. Crnips. Spec. 35.

fagi, (beech gall-fly, black, without spots ; produces pyriform galls on the under side of beech leaves.

Remark. Species are mostly made by the genitive case of the generic name of the plant on which. the insect makes the gall. The generic and specific names are both used in the genitive case for the specific name of the insect when necessary.

See MS P.

\section{9-4. Cyprea. Spec. 118.}

arabica, (lettered porcellane,) shell slightly tur. binate, with irregular graphic characters; stripe down the back simple. 3 inclies long. argus, (ocellate porcellane, shells slightly turbinate, subcylindric, speckled with eye-form spots; 4 browu spots beneath. 
tigris, (tigris porcellane, shell ovate, obtuse behind and rounded before, ferruginous with deep brown spots and a yellowish longitudinal dorsal line.

See MS. P

4-4. Cyprinus. Spec. 56.

barbus, (barbet,) anal fin 7-rayed ; cirri or beards,

4 ; second ray of the dorsal fin serrate each side carpio, (carp,) anal fin 9-rayed; cirri 4 ; second

ray of the dorsal fin serrate behind.

tinca, (tench,) anal fin with 25 rays ; tail entire;

body mucous ; cirri two. Weighs 4 to 8 pounds. cephalus, (chub,) anal fin 11-rayed; body nearly cylindric. May weigh 5 pounds. auratus, (gold-fish, anal fin double, placed like the ventral. A Chinese fish, kept in glass vessels in houses.

leuciscus, (dace, ) anal fin 10-rayed, dorsal-fin 9-

rayed. 6 to 18 inches long. rutilus, (roach, anal fin 12-rayed, reddish ; lateral line bent down, having 36 dots.

See MS. P.

\section{D. \\ 9-1. Dagusa. Spec. 1.}

notata, body marked at one end with a brown spot. 3 inches long.

See MS. P.

1-5. Dasypus. Spec. 10. tricinctus, (three-banded armadillo, bands three, moveable ; toes 5 .

Remarks. The species are named by prefixing: the latin numeral expressing the number of bands to cinctus. As 4-banded, 6, 7, 8, 9, 12, 18. See MS, $P$. 


\section{1-8. Delphinus. Spec. 4.}

phocoena, (porpoise,) body subconic ; back broad; snout bluntish ; bluish above, white beneath ; 46 teeth in each jaw. Appear like old stumps and roots tumbling in water.

delphis, (dolphin,) body oblong, roundish ; snout narrow, sharp. Swims fast. 9 or 10 feet long. orca, (grampus,) snout turned up ; teeth broad, serrate. Var. Sword grampus. Snout subtruncate; teeth pointed.

See MS. $P$.

$$
\text { 5-1. Dentalium. Spec. } 22 .
$$

clephantinum, (elephant-tooth shell,) shell with 10 ribs, slightly curved, striate; green with dark bands, tip white.

See MS. $P$.

\section{8-1. Dermestes. Spec. 85.}

lardarius, (leather-eater, book-eater, black, shell cinereous above. Larva oval, hairy. Very destructive to libraries, museums, bacon, \&c.

See MS. $P$.

$$
\text { 9-1. Derris. Spec. } 1 .
$$

sanguinea, body cylindric, tapering to a point behind; palpi white. In sea. See MS. P.

8-5. Diaperis. Spec. 1.

violacea, blackish-blue; antenuæ ferruginous at the tips. See MS, $P$.

1-3. Didflphis. Spec. 25. opossum, (american opossum, tail hairy near the base; region of the eyebrows paler; teats 5 to 
7. Sometimes the back is dark brown, belly yellowish.

See MS. $P$.

2-5. Didus. Spec. 3.

ineptus, (dodo) black waved with whitish ; head hooded; feet four-toed. Three feet long.

See MS. P.

\section{4-5. Diodon. Spec. 3.}

hystrix, (porcupine fish) nearly spherical ; spines triangular. Sometimes conic with long spines. See MS. P.

2-6. Dromedea. Spec. 4.

exulans, (albatrass, man-of-war) white ; back and wings with white lines; quill-feathers black. See MS. P.

8-12. Diopsis. Spec. 1.

ichneumoniu, (false ichneumon) body reddish ; antennæ small, setaceous; thorax black.

See MS. P.

1-4. Dipus. Spec. 10.

canadensis, (american jerboa) fore toes 4 , hind ones 5 ; tail longer than the body, covered with bristles.

See MS. P.

9-3. Donax. Spec. 19.

trunculus, shell smooth in front, violet within; margins crenate.

Sce MS P.

9-1. Doris. Spec. 24.

argo, (dory) borly oval, smooth, with two small palpi at the mouth ; body red, with black and yellow dots.

See MS. P. 
3-2. Draco. Spec. 1.

volans, (flying dragon) fore legs distinct from the wings ; body ash-colour.

See Ms. P.

8-5. Dytiscus. Spec. 147.

marginalis, (water-beetle) black ; edge round the thorax and outer margin of the shells yellow.

See MIS P.

\section{E.}

4-3. Echeneis. Spec. 3.

remora, (sucking-fish,) tail forked; head with 18 streaks. 12 to 18 inches long. Adheres firmly to ships, \&c. at one end, and fish, \&c. at the other.

See MS. P.

10-1. Echinus. Spec. 109.

esculentus, (sea-hedgehog, sea-urchin,) subglobular; with ten avenues or pores, the spaces between covered with small tubercles supporting the spines; hody reddish or yellowish. See M .

11-2. Fehinorynchus. Spec. 48. gigas, (hog-worm, clear white ; proboscis sheathed, having numerous rows of hooked prickles; suction orifices seven.

Remarks. The species of this genus are named, generally, by the genitive case of the generic names of the animals which they inhabit. See Ms. P.

8-5. Elater. Spec. 183.

tessellatus, (snap-bug;) shell brassy, with crowded paler spots ; claws red. 
seelandirus, (bronze snap-bug,) purple-bronzed, with grey down; shells striate, punctered. An inch and a quarter long. Very common about Troy. Perhaps not the Danish seelandicus.

See MS. P.

1-6. Elephas. Spec. 1.

maximus, (elephant,) body cinereous, seldom reddish or white, very thickly set with hairs ; proboscis flat beneath, tip truncate. Often weighs 4500 pounds

See MS. $P$.

4-4. Exops. Spec. 1.

saurus, tail armed above and beneath ; tail deepcleft.

See MS. P.

2-2. Emberiza. Spec. 61.

nivalis, (bunting, ) quill-feathers white, the primaries black on the outer edge; tail feathers black, the three lateral ones white.

See MS. $P$.

8-12. Empis. Spec. 29.

borealis, black, with roundish, rusty-brown wings; wings large; tail bifid. See MS. $P$.

14-2. Echelis. Spec. 15. punctifera, green, subcylindric, obtuse before, pointed behind. In marshes. See MS. $P$.

10-1. Encrinus. Spec. 1. conulus, (encrinite,) body conic or eliptical ; mouth 16 
in the middle of the base; branches cylindric, with rings. Common petrifaction.

See MS. $P$.

8-8. Ephemera. Spec. 21.

vulgata, (ephemera, day-fly,) wings reticulate, spotted with brown ; body yellowish, spotted with black; having three threads at the end of the abdomen. Species communis of some authors. It appears by millions, ascending and. descending, for a few days.

See MS. $P$.

$$
\text { 4-3. Eques. Spec. } 2 .
$$

americanus, rays of the first dorsal-fin elongated; teeth smooth ; the floating resicles large.

See MS. $P$.

$$
\text { 1-6. Equus. Spec. } 6 .
$$

caballus, (horse,) hoofs solid; mane and, tail with long flowing hair.

hemionus, (wild mule,) hoofs solid; colour uniform, no cross on the back; tail hairy at the tip only.

asinus, (the jack,) hoof solid ; tail bristly at the extremity; a black cross on the shoulder of the male.

see MS. P.

1-3. Erixaceus. Spec. 6.

europreus, (hedgehog,) ears rounded ; nostrils with a loose flap. About ten inches long.

See MS. $P$.

4-4. Esox. Spec. 15. osseus, (bill-fish, sea-pike,) upper jaw longer ; scales bony ; tail quadrangular. 
vulpes, (sea-pike,) dorsal fin in the middle of the back ; gill-membrane five-rayed. qucius, (bill-fish,) snout depressed; jaws nearly equal.

belone, (gar-pike,) each jaw long, subulate. See MS. $r$.

4-4. Exocœtus. Spec. 3.

yolitans, (flying-fish,) belly keeled each side; flies from wave to wave by its pectoral fins. Sea MS. $P$.

\section{F.}

2-1. Falco. Spẹc. 126.

Section A. Feet generally rough.

thelanatos, (black eagle, cere yellow ; feet yellow; somewhat downy; body rusty-black with yellow streaks; outer part of the tail white with blackish spots. 3 feet long.

leucocephalus, (bald eagle,) cere and legs yellow ; legs somewhat downy; body brown; head and tail white; claws black. 3 feet long.

fulvus, (ring-tail eagle,) cere yellow ; legs downy, rusty; back brown; tail with a white band;

breast with a triangular spot. lagopus, (rough-leg hawk, cere, and downy legs, yellow; body black spotted with white; tail feathers white, black towards the tip. 2 feet long.

milvus, (kite,) cere yellow ; tail forked; body ferruginous; head whitish. 2 feet long. haliatos, (bald buzzard,) cere and feet blue ; body brown above, white beneath; head white. 2 feet long. 


\section{Sec. C. Legs naked.}

borealis, (american buzzard,) cere and legs paleyellow; body brown above, white beneath : tail pale rusty, with a transverse rusty bar near the tip. 20 inches long.

palumbarius, (goshawk, cere black, edged with yellow; legs yellow; body brown; tail-feathers with pale bands; eyebrows white. 22 inches long.

gentilis, (gentle falcon,) cere and legs yellow:

body cinereous with brown spots; tail with four blackish bands. About 2 feet long.

communis, (common falcon,) body brown ; feathers rusty-edged ; tail with dark transverse bands ; bill ash-blue ; cere, iris and legs, yellow. Colour varying in different countries. hyemalis, (winter hawk,) cere yellow; head and back black-brown; neck streaked with white; breast and belly white with heart-spots. 20 inches long.

cyaneus, (hen harrier, hen hawk,) cere white ; leg's tawny; body hoary blue; a white arch over the eyes surrounding the chin; pale-brown spots on the hind-head; breast and belly white. 17 inches long.

fuscus, (american liawk, cere cinereous; legs yellow; body waved with black, ash-brown above, white beneath. 14 inches long.

dubius, (ground-coloured hawk, cere and legs yellow; head dusky with rusty streaks; body brown above, dirty white with brown streaks beneath; tail dusky-ash with four black bands. 10 inches long.

obscurus, (dusky hawk,) cere and legs yellow: 
hind-head and neck spotted with white; body dusky-brown above, white with black lines beneath ; tail with 4 broad and 4 narrow bands, tip white.

columbarius, (pigeon hawk, cere and legs yellow; body brown, whitish beneath ; tail brown with 4 white lines. 10 inches long

See MS. $P$.

\section{1-2. Fasciola. Spec. 46.}

hominis, (gourd-worm, fluke,) found in men ; tlat. See MS. $P$.

$$
\text { 1-3. Felis. Spec. } 23 .
$$

Section A. Tails long; ears plain.

catus, (cat,) tail with numerous rings.

See MS. P.

\section{Varieties.}

1. Common domestic cat. Hair short, thick g body small.

2. Wild cat. Body with blackish stripes; three dorsal lines longitudinal, lateral ones spiral.

3. Angora cat. Hair long, silvery, silky, longest on the neck.

4. Tortoise-shell cat. Variegated with black, white and orange.

5. Blue cat. Hair bluish-grey.

6. Red cat. A red stripe from the head down the back.

7. Chinese cat. Ears pendulous ; hair shining, variegated with black and yellow.

8. Yellow cat. Reddish-yellow ; head long, snout sharp; legs short, claws weak; ears round, flat.

9. Madagascar cat. Tail twisted. 
leo, (lion,) body pale tawny, shaggy ; long mane on head and neck; tail bushy at the end. 8 feet long.

tigris, (tiger,) body with dark long transverse stripes on a pale-yellow ground. 12 to 15 feet long.

pardus, (panther,) upper parts of the body marked with circular spots, lower with stripes on a bright tawny ground. 7 feet long. encia, (ounce,) body whitish, with irregular black spots. 3 feet long.

leopardus, (leopard,) body yellow with black spots, which are nearly in contact. 3 feet long. pardalis, (mexican cat,) body striped above, spotted beneath. 4 feet long. concolor, (brown tiger, ) body tawny, without spots.

12 to 15 fect long. See MS. P.

Sec. B. Tails short; ears pencilled at the tips. onontana, (mountain lynx, ears upright, pointed, having two transverse streaks; long narrow stripes on the back, and numerous round spots on the sides and legs. 2 feet long.

mafa, (bay lynx,) tail black-banded above, white beneath and at the tip; body tawny, spotted with brown; ears bearded at the tips. 2 feet long.

Yynx, (lynx,) tail with obscure rings, black at the tip ; head and body light-tawny, spotted with black; ears bearded at the tips. Size of a fox. See MS. P.

11-1. Filaria. Spec. 18.

medinensis, (thread-worm,) borly entirely paleyellowish. 
lepidopterorum, (butterfly and miller worm, tail hooked.

See MS. $P$.

4-4. Fistularia. Spec. 3.

tobacaria, (tobacco-pipe,) tail bifid, ending in a slender tapering whip.

See Nis. $P$

13-2. Flustra. Spec. 18.

faliacea, (horn-wrack,) foliaceous, branched, witls rounded wedge-form subdivisions.

See Mis. P

8-6. Forficula. Spec. 18.

auricularia, (earwig;) dark chesnut; forceps curved, toothed at the base ; antennæ with 14 joints. See MS. $P$.

8-9. Formica. Spec. 70.

hercularea, (black ant or emmet,) black ; abdo. men ovate ; legs ferruginous. rufa, (red-leg ant,) black; thorax compressed, legs rufous.

fisca, (brown ant, grey-brown, polished ; antennae and legs ferruginous ; wings white. rubra, (red ant,) testaceous; eyes and dot under the abdomen black.

crspitum, (flying ant,) black; petiole of the abdomen with two tubercles; scutel two-toothed. Fly freely in fair weather, from beneath mossy hillocks.

See MS. $P$.

2-2. Fringilla. Spec. 112.

lapponica, (fiuch,) head black; body grey and black; eyebrows white; outer tail feathers with a white wedge-form spot. 6 inches long. 
coelebs, (chaffinch,) limbs black ; quill-feathers: white on both sides, the three first without spots, two of the tail-feathers obliquely white. carduclis, (goldfinch, quill-feathers black, and (except the outermost, marked with fine yellow in the midile : two outermost tail-feathers white in the middle, and the rest tipped with white. Colours variable.

linaria, (little redpole, ) brown, varied with grey, reddish-white beneath; wings with a double white band; crown and breast red. 5 inches long.

linota, (linnet, ) chesnut-brown, beneath whitish ; wings with a longitudinal white band; tailfeathers each side edged with white. 5 inches long.

domestica, (house-sparrow, quill and tail-feathers brown; body grey and black; wings with a single white band. 6 inches long.

montana, (tree sparrow,) quill and tail-feathers brown; body grey and black; wings with a single white band. 5 inches long. See MS. $P$.

8-7. Fulgora. Spec. 25. lanternaria, (lantern fly,) front extended, strait; wing-cases variegated; wings each having a large ocellate spot.

See MS. $P$.

2-5. Fulica. Spec. 25.

chloropus, (moor-hen,) front tawny; bracelets red; body blackish. 14 inches long. novceboracensis, (galliuule,) legs brown ; crown. and neck above olive, spotted with white; back brown; breast dirty yellow. Size of a quail, 
atra, (coot,) front flesh colour; bracelets greenish yellow; hody blackish; feet pinnate. 15 inches long.

See MS. $P$.

\section{1-2. Furia. Spec. 1.}

infernalis, (finland pest,) thread-form ; entering under the skins of animals.

see MS. P.

G.

4-2. Gadus. Spec. 23.

morhua, (codfish, dorsal fins three; mouth beard-

ed ; tail subequal; first aual ray spinous. 2

to 4 feet lorrg.

eglefinus, (haddock, dorsal fins three ; mouth bearded; whitish ; tail forked ; upper jaw larger.

See MS. P.

2-3. Galbula. Spec. 4.

viridis, (jaca mar,) tail wedge-form ; body goldengreen, rufous beneath; chin white.

see MS. P.

1-3. Galeopithecus. Spec. 1.

volans, (flying-cat,) reddish-grey above, rose colour beneath.

See MS. $P$.

4-3. Gasterosteus. Spec. 13.

aculearus, (stickle-back,) dorsal spines three; gill-covers large, silvery ; fins yellowish. 3 inches long.

saltatrix, (ship-jack, dorsal-spines eight, connect- 
ed by a membrane; gill-membrane 7 -rayed: Resembles a perch.

See MS. P.

4-6. Gastramanchus. Spec. 1.

caecus, (hag-fish,) glutinous ; eight inches long; worm-like.

See MS. $P$.

2-5. Glareola. Spec.3.

nusiriaca, (pratincole,) grey-brown above ; collat black; chin and throat white; breast and belJy reddish-grey. 9 inches long. See MS. $P$.

\section{2-2. Glaucopis. Spec. 1.}

cinerea, (wattle-bird,) body, bill and legs black; tail long. 15 inches long.

See MS. $P$.

4-3. Goblomores. Spec. 4.

strigatus, first caudal-fin 6-rayed ; head compressed, yellow. Taken from Gobius.

See MS. $P$.

4-3. Gobius. Spec. 21.

niger, (goby,) second dorsal-fin with 14 rays. 6 inches long.

Seo MS. $P$.

14-2. Gonium. Spec. 5.

pectorale, quadrangular membrane pellucid, with sixteen spherical molicules set in it.

See MS. $P$. 


\section{4-3. Gomphorus. Spec. 1.}

cerulius, head and lips smooth ; snout tubiform, elongated.

See MS. P.

\section{5-3. Gurdius. Spec. 5.}

buaticus, (hair-snake, pale brown with dark extremities. 4 to 10 inches long. Whitlows have have been caused by the bite of it. It has been supposed by the vulgar to be an animated hair, accidentally dropped into water. Its rings and mouth demonstrate the folly of the supposition. Set MS. P.

\section{3-2. Gorgonia. Spec. 41.}

anceps, (red coral-bush,) slightly branched, with compressed stem and branches; each with a row of florets along both the margins. 24 inches high. See MS. P.

2-2. Gracula. Spec. 13.

barita, (grakle,) greyish ; shoulders blue ; quillfeathers outside green. 13 inches long. See MS. P.

\section{8-6. Grullus. Spec. 251.}

Section A. Antennæ setaceous; feelers unequal; thorax rounded; tail with two bristles. Cricket family.

sryllatalpa, (mole cricket,) wings terminating in slender tails, longer than the abdomen; forefeet palmate. Burrows in the ground in gardens. domesticus, (hearth cricket,) wings tailed, longer than the wing-cases; body glaucous. 
campestris, (field cricket,) wings shorter than the wing-cases; body blackish ; style linear.

Section B. Antennæ filiform; feelers simple; tail simple; throat with a horn-like protuberance. Grasshopper and Locust family.

migratorius, (egyptian locust,) thorax of a single segment, subcarinate; mandibles blue; body brown, varied with dark spots; legs blue ; hind thighs and shanks yellowish.

grassus, (grasshopper,) thighs sanguineous ; wingcases greenish ; antennæ cylindrical. See Nis. P.

$$
\text { 4-3. Gymnetrue. Spec. } 1 .
$$

cepedianus, pectoral-fins small; upper jaw much extended; teeth very small.

See MS. P.

\section{4-1. Grunotus. Spec. 9.}

electricus, (electrical eel,) naked, brown, without dorsal-fin : candal-fin obtuse and joined to the anal. 3 to 6 feet long.

See MS. P.

8-5. Grainus. Spec. 11.

natator, (water-flea,) oval, black, obscurely striate. Plunge under water when disturbed, drawing a bubble resembling quicksilver in appearance.

See MS. P.

H.

2-5. Hematopus. Spec. 1.

ostralegus, (sea-pie, oyster-catcher,) bill, eyelids and legs red; body black, sometimes white beneath.

See MS. P. 
9-4. Haliotis. Spec. 19.

taberculata, (sea-ear,) shell subovate, the outside transversely grooved, rugged and tuberculate. 4 or 5 inches long.

see MS. P.

9-4. Helix. Spec. about 380.

Remark. The following species of the helix, including the planorbis and lymnza sections, are taken mostly from Say and Barnes. They are the most common American fresh-water and shell. marle species.

Section A. Proper Helix. Spire convex ; aper. ture wider than lung.

albilabris, (common snail, white-lip snail,) shell thin, fragile, convex, not perforated; whorls 6, obtusely wrinkled crosswise, spirally striate, with very fine lines; aperture lunate and regularly curved; lip flat, white. About an inch broad.

thyroidus, (small white-lip snail,) lip not flat, white: a strong oblique tooth on the pillar-lip. Breadth about three fourths of an inch. arboreus, (dwarf snail, bark snail,) shell very thin, fragile, depressed, horn-colour, pellucid; whorls four, irregularly wrinkled crosswise; aperture sublunated ; lip thin ; umbilicus large and deep. Breadth not the fourth of an inch. Often under decaying bark of trees. tridentata, (three-toothed snail,) shell depressed, brownish or horn-colour; whorls five, crossed by numerous raised, equi-distant, acute lines, separated by regular grooves; aperture lunate, 
3.toothed; one of the three on the pillar lip, other two on the outer white lip. Breadth about half an inch.

alternata, (striped snail,) shell somewhat convex, striped with alternating rays of a light and dark colour ; whorls five, crossed by equi-distant raised lines; lip curved, with a pearly hue within ; umbilicus large. Breadth about threefourths of an inch.

glaphyra, (shining snail,) shell much depressed, smooth, pellucid, thin, fragile; whorls five, rounded, obsolete irregular cross wrinkles; whitish beneath ; umbilicus middling. Breadth about half an inch.

Section B. Flat-orbed Helix, or Planorbis of Bruguieres. Spire depressed or sunk, so as not to be raised above the central plain of the whole coil.

trivolvis, (short-tail snail,) shell sinestral (coiling from left to right, beginning at the tip of the spire, when the back of the animal is upwards,) pale yellow, brownish chesnut; somewhat keeled above and beneath, particularly in the young state ; whorls three or four, with raised, equidistant, fine cross lines ; spire concave ; aperture large, bluish-white within ; umbilicus large. Largest breadth about half an inch. Sometimes it is a little larger, very dark coloured, with a reddish mouth within.

bicarinatus, shell sinistral, pale yellow or brownish, somewhat keeled above and translucent beneath ; spire retuse-umbilicate, forming a cavity as deep as that of the base; aperture large, 
reddish-brown within; whorls three, wrinkled, with minute revolving lines. Largest breadth about half an inch.

parvus, (dwarf short-tail snail,) shell horn-colour or blackish; whorls four, crossed by minute wrinkles; concave above and beneath; lip rounded; mouth bluish within. Breadth less than the fourth of an inch.

Section C. Tapering Helix. Lxmnate of Lamarck. Spire terete, or conical.

catascopius, (conk snail,) shell thin, horn-coloured or blackish; whorls 4 or 5 ; the first large and swelling, and the remainder decreasing rapidly to an acute apex, and are wrinkled crosswise ; aperture large, oval, not equalling threefourths the length of the shell. Breadth about half an inch, length about three fourths of an inch.

heterostrophus, shell sinistral, subovate, pale yellow or brown; whorls 4, first large, the other tapering abruptly to an apex; aperture large, somewhat oval, three-fourths equal to the length of the shell, pearly or blackish within, lips reddish. About half an inch broad and threefourths of an inch long.

subcarinatus, shell with three rounded subcarinate whorls, reticulated with strix; suture deep; apex truncate; aperture oval, equal to more than half the length of the shell. Length a little over half an inch, breadth less. virginica, shell tapering to the apex, and also a little towards the base; horn colour, blackish or olive; tinged with green under the epidermis 
or skin ; whorls 7, crossed on the spire by curved wrinkles and somewhat on the body ; aperture subovate, about a third as long as the shell. Length about an inch, breadth more than equal to a third of the length. A Buccinium of Gmelin.

vivipara, shell subconic, with six rounded whorls, suture impressed ; olive or pale, having three reddish-brown bands; aperture suborbicular, equalling about half the length of the shell. Length about an inch, breadth about two - thirds as much.

decisa, shell subconic, olive ; apex minute, whorls four, wrinkled across and banded with minute distant striæ; terminal whorl very short ; suture impressed; aperture subovate, about half the length of the shell ; bluish-white within. Length about an inch, breadth about threefourths as great.

Sce MS. P.

8-8. Hemeromies. Śpec. 4.

pulsatorium, (false death-watch,) mostly wingless : abdomen oblong; mouth red; eyes yellow. The female makes a noise like the ticking of a watch, or like the Ptinus pulsator.

See MS. P.

8-12. Hippozosca. Spee. 5.

equina, (horse-fly,) wings obtuse ; thorax variegated; feet armed with four claws; head brown ; wings crossing. ovina, (sheep-bug, destitute of wings; body dull testaceous. See MS. P. 


\section{5-3. Hirudo. Spec. 17.}

medicinalis, (doctor's leech,) elongated, olive-black with yellow ferruginous lines above, and spotted with yellow beneath.

sanguisuga, (blood-sucker, horse-leech,) elongated, olive-brown, with an ochre-yellow marginal band.

See MS. P.

2-2. Hinundo. Spec. 38.

Section A. Toes three before and ane behind. rustica, (swallow, front and chin chesnut; tailfeathers, except the two middle ones, with a white spot; bill black. 6 inches long. urbica, (martin bird,) bluish-black, white beneath ; tail-feathers without spots; bill black; mouth yellow. Five and a half inches long.

riparia, (sand-bank martin, bank swallow, cinereous; chin and belly white; bill blackish ;

throat encircled with a mouse coloured ring.

pelasgia, (chimney swallow, tail-feathers equal, naked and subulate at the tip; body and bill brown ; chin whitish. Four and a quarter inches long.

Section B. Toes all placed forward. apus, (steeple swallow, barn swallow, blackish ; chin white; feet small, scaly, fit for walking; but adapted to clinging to walls. 7 or 8 inches long. Is much of its time on the wing. See Ms. P.

8-5. Hister. Spec. 25. unicolor, black; shells obliquely striate. See MS. P. 
4-3. Holocentrus. Spec. 1. soso, having red and yellow bright shining lines. See MS. P.

\section{0-1. Holothuria. Spec. 23.}

pentactes, with ten branching tentaculæ; body with five rows of papilla. Six inches long.

See MS. P.

$$
\text { 1-1. Homo. Spec. } 1 .
$$

sapiens, (man,) body mostly naked; head covered with hair or wool; face naked; nails broad.

\section{Varieties, more or less permanent.}

Caucasian, (white european,) colour reddish-white; head oval, covered with hair, straight, undulated or curled. In disposition restless, impatient under restraint, fond of novelty and of change. Minds adapted to deep investigation, original invention, devotion, friendship, benevolence.

Ethiopian, (black negro,) colour black ; head ob. lique covered with wool, harsh, curled. In disposition patient in servitude, sensual, indifferent to novelty and change. Minds adapted to low cunning and the pursuit of sensual gratification; mostly incapable of deep research, of devotion, friendship or benevolence ; but there are many exceptions.

Mongoliz n, (copper-coloured indian,) colour and other characteristics intermediate between the Caucasian and Ethiopian. Head broad, hair straight. In disposition sensual, fond of roving abroad, sly, cunning, treacherous. Somewhat qualified for research ; not wholly destitute of 
benevolence and friendship, but mostly too fickle to be entitled to confidence.

\section{Varieties not permanent.}

Agarico, (mushroom growth,) thick, swollen, all parts unusually disdented in early life, and not in conformity with ancestral lineage.

Albino, hair milk-white; skin of a deathly white; eyes weak and tremulous. This variety is common to the three permanent varieties, and its peculiarities are not hereditary.

Remarks. The three primitive varieties are intermixed in all proportions. But in some countries they remain distinct through many generations. The Egyptian mummies appear to have been Mongolians ; therefore the present variety seems to have remained unchanged three thousand years. We find but few specimens of either of the three varieties, in perfection in North America. Most negroes of the Northern states have lost chiefly their primitive Ethiopian character; and many European Caucasians seem to partake of the characteristics of the three varieties.

See MS. P.

\section{3-1. Hydra. Spec. 5.}

viridis, (green jelly,) tentaculæ about ten, shorter than the body. Appears like a drop of green jelly on the under surface of plants in water when at rest, but is linear and fixed at one end when in action, with its tentacula extended. In fresh water.

See MS. P. 
8-5. Hyorachna. Spec. 49.

globator, (water spider, body globular, with red eyes.

See MS. P.

8-5. Hrdrophilus. Spec. 31.

piceus, (water-clock, glossy-black; sternum channelled with a long spine pointing backwards. scaraboides, (beetle water-bug,)black; shell striate; legs piceus. Sec MS. P.

3-3. Hydrus. Spec. 1.

hydrophis, (water-serpent, head small, furnished with large plates.

See MS. P.

1-6. Нippopotamus. Spec1. amphibius, (river-horse,) feet four-lobed; skin thick, dark, almost naked ; teeth very white ; tail short, naked.

See MS. P.

1-6. Hyrax. Spec. 2.

capensis, nails of the fore feet flat, of the hind feet subulate, single.

See MS. P.

1-4. Hrstrix. Spec. 5.

dorsata, (american porcupine,) rusty-brown ; tail middling length, not prehensile; hind feet fivetoed ; spines on the upper part of the head, back and tail only. Var. white.

see MS. P. 


\section{I.}

\section{8-9. Ichneumon. Spec. 492.}

lunator, (american ichneumon,) varied with black and yellow; abdomen clavate, with yellow lunules each side; sting twice as long as the body. Deposites its eggs in the perforated body of the larva of other insects. See MS. P.

\section{3-2. Isis. Spec. 6.}

entrocha, (entrochite coral, stem testaceous, round, pentagonal, with orhicular perforated joints and whorled dichotomous branches. It is found living in the ocean and in the fossil state. asteria, (star-stone,) stem testaceous, jointed, pentagonal; branches whorled. See MS. P.

\section{8-1. Julus. Spec. 14.}

ovatus, (round decipede,) legs ten each side. terrestris, (round centipede,) legs one hundred each side; body polished, blackish. subulosa, legs one hundred and twenty each side. maximus, legs one hundred and thirty-four each side; body brown. See MS. $P$.

K.

4-2. Kuntus. Spec. 1. indicus, head large, compresserl, obtuse ; back spotted; pectoral and ventral fins yellow edged with red.

Sce MS.P. 


\section{L.}

4-3. Labrus. Spec. 71.

tinca, (old wife,) upper jaw turned up ; tail rounded.

See MS. $P$.

3-2. Lacerta. Spec. 72.

Sec. A. Tail two-edged.

crocodilus, (crockodile,) head armed ; nape keeled ; tail above with two lateral crests. 18 to 25 feet long.

alligator, (alligator,) head flat, imbricate ; tail above with two rough lateral lines.

Sec. B. Body covered with carinate scales. bimaculata, (lizard,) tail carinate, toothed, twice as long as the borly; all the toes lobate. monitor, (lizard,) tail carinate ; body unarmed, with ocellate spots. Green, checked, cinereous or blue.

Sec. C. Feet 5-toed, tail round.

chameleon, (chameleon,) head flat; body cinereous or white. Colour changeable.

Sec. D. Collar double; abdominal scales square. agilis, (scaly lizard,) tail whorled, longish, with sharp scales ; collar scaly beneath. Green, brown, bluish, speckled. See MS. P.

8-5. Lampyris. Spec. 52.

noctiluca, (glow-worm,) oblong, brown ; shield cinereous. The female is the largest, and emits a bright phosphoric light. See $M S$. $P$. 


\section{9-1. Laplisia. Spec. 2.}

depilans, (sea-hare,) body pale lead-colour, without spots. Two to five inches long. See MS. $P$.

3-3 Langaya. Spec. 1.

nazutn, head furnished with large plates; mouth long, pointed.

See MS. $P$.

\section{2-2. Iuanius. Spec. 43.}

canadensis, (shrike,) tail wedgeform ; head crested; body reddish, whitish beneath. 8 inches long.

excubitor, (great shrike,) tail wedgeform, white at

the sides; back hoary; wings black with white spots.

americanus, (american shrike,) black; spot on the first quill-feather, cheeks and chin white : breast and belly cinereous.

See MS. $P$.

2-6. Larus. Spec. 15.

Sec. A. Nostrils without a cere.

tridactilus, (tarrock gull,) back whitish ; quillfeathers white; hind-toe unarmed.

canus, (common gull,) white; back hoary ; primary quill-feathers black at the ends, the fourth and fifth with a black spot at the tip, the outer black without.

marinus, (black-back gull,) white with a black back.

fuscus, (herring gull) white, with a brown back ; legs yellow. 
Sec. B. Nostrils covered with a cere. parasiticus, (arctic gull,) two middle tail-feathers very long crepidatus, (black-toed gull,) varied with dirtywhite and brown, pale beneath ; two middle tail-feathers a little longer. 16 inches long. caturactes, (skua-gull,) greyish ; quill and tailfeathers white at the base ; tail sub-equal. See MS. $P$.

1-2. Lemur. Spec. 13.

volans, (flying cat,) tailed ; surrounded by a membrane formed for flying.

See MS.P.

$$
\text { 9-2. Lepas. Spec. } 32 .
$$

intertexta, (acorn-shell,) subdepressed ; valves imbricate and obliquely striate. Adhering to oysters, \&c.

titinnabulum, shell conic, obtuse, bellform, rugged ; fixed to bottoms of ships, \&c. purplish and bluish.

anatifera, (duck barnacle,) shell compressed, fivevalved, smooth, seated on a peduncle. In clusters on ships' bottoms, \&c. Bluish-white. See MS. P.

8-2. Lepisma. Spec. 7. saccharina, (sugar lepisma,) scaly, silvery, leadcolour, with a tripple tail. Runs swiftly. Often found in sugar.

See MS. P.

\section{4-1. Leptocephalus. Spec. 1.}

morrisini, (morris,) body almost transparent ; dorsal fins low and thin, extending the whole length of the back. 4 inches long. See MS. P. 


\section{8-5. Leptura. Spec. 126.}

aquatica, (wood-beetle,) hind-thighs two-toothed; shells shining green; hind-shanks five toothed. See MS P.

\section{1-4. Lepus: Spec. 15.}

timidus, (hare,) tail short ; ears black at the tip, longer than the head; body whitish, brownish, or straw-colour.

americanus, (rabbit, american hare,) tail short; hind-legs half as long-again as the body; tips of the ears and tail grey.

cuniculus, (rabbit,) tail short, nearly the colour of the body; ears black at the tip; hind-legs shorter than the body; grey, black, or white, with red eyes.

See MS. P.

11-1. Lernan. Spec. 15.

branchialis, (codfish-worms,) body round, flexuose ; mouth lateral, seated between three slightly branched horns. About 2 inches long. On the gills of codfish.

See MS. P.

14-2. Lencophia. Spec. 8. nodulata, (worm-eater,) oblong-ovate, depressed; with a double row of tubercles. In angleworms.

See MS. P.

8-8. Libellula. Spec. 56.

Section A. Wings expanded when at rest.

quadrimaculata, (dragon-fly,) lower wings at the base, and all in the middle on the fore part. 
with a blackish spot; abdomen depressed downy.

depressu, all the wings blackish at the base. oulgata, wings hyaline without spots; abdomen cylindric rufous. oulgatissima, thorax yellow with 8 black streaks.

Section B. Wings erect when at rest.

virgo, wings coloured; body greenish-blue, silky or green.

puella, wings hyaline, not coloured; body red, spotted, blue, cinereous or blueish-green. See MS. P.

11-2. Ligula. Spec. 2.

abdominalis, (fish-worm, pale-ash, broad. From

6 inches to 5 feet long. In the intestines of fish. See MS. P.

$$
\text { 9-1. Limax. Spec. } 15 .
$$

ater, (black slug, naked snail,) body black and furrowed with deep wrinkles. From one to five inches long. Crawls slowly leaving a slimy track.

maximus, (large slug,) body cinereons, with or without spots. 4 or 5 inches long. agrestis, (field slug,) body whitish; with black antennæ. Half an inch long. See MS. P.

$$
\text { 9-1. Lobaria. Spec. } 1 .
$$

quadriloba, tail with four lobes. See MS. P.

4-3. Lonchurus. Spec. 1. barbatus, brown, with two cirri under the chin ; body brown. About ten inches long. See US. $P$. 
4-5. Lophus. Spec. 8.

piscatorius, (fishing-frog, angler,) body depressed; head rounded. Sometimes seven feet long.

See MS. $P$.

4-4. Loricaria. Spec. 2.

cataphracta, (harness-fish,) dorsal fin single ; cirri

two; tail forked, with one bristle-form ray.

See MS. $P$.

2-2. Loxia. Spec. 100.

curvirostra, (crossbill,) mandibles crossing each other; body varying in colour; wings and. forked tail brown. 6 inches long.

pyrrhula, (bullfinch,) cinereous ; head, wings and tail black; coverts of the tail and hindmost quill-

feathers white. Black or white. 6 inches long, abscura, (dusky grosbeak,) middle of the throat and double band on the wing-coverts white; quill-feathers green; flanks white, spotted with brown.

Sce MS. $P$.

8-5. Lucanus. Spec. 27.

cervus, (stag-beetle,) jaws exsert, forked at the tip, a small branch near the middle within. Larva fat whitish, with ferruginous head and legs.

See MS. $P$.

12-1. Iudernaria. Spec. 3.

bnadricornis, body long, coiled, with four forked arms, tentaculate at the tip; no head or eyes. See MS. P

5-3. Lumbricus. Spec. 16. terrestris, (angle-worm, earth-worm, dew-worm,) 
body red, with eight rows of prickles which are invisible to the naked eye; 140 rings with four pair of prickles to each. See MS. $P$.

1-3. Lutra. Spec. 8.

canadensis, (otter,) hind feet palmate; black ; fur smooth ; tail long, tapering.

communis, (common otler, hind feet palmate, naked ; tail half as long as the body ; fur deep brown ; whiskers large ; ears short ; feet fivetoed. 2 feet long.

See MS. $P$.

\section{M.}

1-3. Macropus. Spec. 3.

major, (kanguroo, tail long, thick ; hind feet three times as long as the fore feet; three-toed. See MS. P.

\section{4-3. Macrourus. Spec. 1.}

mupestris, dorsal fins two, the first ray of the first fin toothed backward. Three feet long. See MS. P.

$$
\text { 9-3. MactRA. Spec. } 16 .
$$

solida, shell opake, smoothish, sub-antiquated. lutraria, shell oblong-oval, smooth, without late-

ral teeth. Resembles a Mya.

See MS. P.

13-2. Madrepora. Spec. 118.

Section A. Composed of a single star.

turbinata, (stone knot,) turbinate, sessile, with a a hemispherical concave star. Found fossil. 
cormuta, (stone horn,) turbinate, elongated, curving towards one side. From half an inch to two inches in diameter at the base and tapering upwards to a point. Found fossil.

Section B. Composed of numerous stars.

phrygia, with long narrow undulations, and perpendicular prominent ones; stars confluent; partitions simple, lamellate, lobulate; lamina rather remote. Found both recent and fossil. porites, (fungu--stone,) slightly branched; stars separate, crowded; composite, rough. White or grey; branches clavate, very obtuse. Found recent and fossil.

See Mis P.

1-5. Manis. Spec. 2.

pentadactyla, (scaly ant-eater,) feet five-toed. 6 or 8 feet long.

Sce Ms. P.

8-6. Mantis. Spec. 64.

calamus, (walking stick, body filiform, cylindric-

al, apterous, greenish ; thighs striate ; anten-

næe yellowish.

bispinosa, (winged-stick, spectre, thorax roundish, with two spines on the fore part; wing-cases very short; wings rose-colour.

see MS. P.

1-6. Mastodon. Spec. 2.

giganteum, (extinct,) the truncate ends of the teeth are rhombic or diamond-form. angustidens, (extinct,) ends of the teeth three-loleed, or like the club-spot on cards. See MS. $P$. 
12-2. Medusa. Spec. 45. cruciata, (crossed jelly, body marked with a milkwhite cross, jelly-like, transparent, surrounded at the margin with fine fibres.

See MS. $P$.

1-5. Megatherium. Spec. 2.

americanum, (extinct,) occiput elongater, flattened, convex above the eyes; whole fore foot touches the ground.

See MS. $P$.

\section{2-4. Meleagris. Spec. 2.}

gallipavo, (turkey, front and chin carunculated ; breast (of the male,) lufted. Three and a half feet long. Found wild in many parts of this country. When domesticated it varies much in colour.

See MS. $P$.

8-5. Mele. Spec. about 60.

pensylvanica, (black spanish fly,) entirely black, opake.

vesicatoria, (spanish-fly,) green ; antennæ black. On ash and elder trees. Canthanis of Olivier. Lytra of Fabricius. See Latreille, p. 316 , and $o$.

See MS. P.

2-6. Mergus. Śpec 10.

merganser, (goosander,) subcrested ; white; head, neck, upper part of the breast and wings glossy. llack ; tail cinereous.

castor, (dun-diver,) crested, cinereous ; head and upper part of the neck bay ; chin, middle quillfeathers and belly white. Two feet long. See MS. $P$. 
2-2. Merops. Śpec. 26.

apiaster, (bee-eater, back ferruginous; belly and tail bluish-green ; two of the tail-feathers longer; chin pale-yellow; bill black; crown, hind-head and neck bay.

See MS. $P$.

13-2. Millepora. Spec. 34.

polymorpha, (common coral,) crustaceous, solid, irregularly shaped, but generally branched and tuberculate, and without visible pores. See MS. P.

\section{2-2. Momotus. Spec. 1.}

brasiliensis, (motmot,) green ; front bluish-green ; hind-head violet; crown black. See MS. $P$.

\section{4-2. Monas. Spec. 5.}

lens, transparent, with sometimes a greenish margin ; a mere round pellucid dot.

See MS. P.

6-2. Monoculus. Spec. 68.

cyclops, (horse-foot,) shell convex with three lines of raised spines; tail very long and unarmed. See MS: $P$.

\section{1-8. Monodon. Spec. 1.}

monoceros, (narwal,) skin white, spotted with black on the back ; no dorsal fin; two small pectoral ones. 18 to 40 feet long. See MIS. $P$.

4-1. Monopterus: Spec. 1. notopterus, silvery with a gilt hue; fins pale ash. See MS. $P$. 


\section{8-5. Mordella. Spec. 34 .}

cessleata, tail ending in a short point; body black,

without spots.

see MS. P.

4-4. Mormyrus. Śpec. 3.

enguilloides, tail bifid, obtuse ; dorsal fin with 63

rays.

See MS. P.

\section{1-7. Moschus. Spec. 6.}

moschiferus, (musk, a musk-bag near the naval; tail short; fur soft, blackish-brown and white. Two and a half feet long. See MS. P.

\section{2-2. Motacilla. Spec. 200.}

luscina, (nightingale,) rufous-ash, white-ash be. neath; tail-feathers rufous-brown; bracelets cinereous. 6 inches long. Sings from April till fall.

modularis, (hedge-sparrow,) above grey-brown; wing-coverts tipped with white; breast bluishash. Five and a half inches long. Sings all winter.

alba, (tipe-up, wagtail,) breast blackish ; two lateral tail-feathers obliquely half white. Sometimes whitish and cinereous. About 7 inches long.

rubicola, (robin-redbreast,) grey; throat and breast ferruginous.

troglodytes, (wren,) grey ; eyebrows white ; wings waved with black and cinereous; bill dark brown. Three and a half inches long. see MS. P. 
4-4. MugiL. Spec. 5.

cephalus, (mullet, ) first dorsal fin 5-rayed.

See MS. P.

4-3. Mullus. Spec. 6.

surmuletus, (surmullet, cirri two ; body with four longitudinal yellow lines. From 6 to 24 inches long.

See MS. P.

4-1. Murena. Spec. 8.

ophis, (spotted sea-serpent, snake-eel,) body slender, spotted ; tail round, spear-form, naked. 3 to 4 feet long.

See MS. P.

\section{9-4. Murex. Spec. 182.}

tribulus, (thorny woodcock, shell ovate with a tripple row of setaceous spines ; beak elongat. ed, subulate, with spines.

erinaceous, (hedgehog oyster,) shell subangular ; whorls crowned with tubular and subspinous raised scales or points ; beak short and covered. See MS. P.

\section{1-4. Mus. Spec. 46.}

zibethecus, (musk rat,) tail long, compressed, lanceolate; feet cleft. A foot long.

decumanus, (norway rat, dock rat,) tail very long, scaly ; bodly bristly, grey above, whitish beneath. Body nine inches long, tail seven. Tail has about 200 rings.

rattus, (black rat, ship rat,) tail very long, scaly ; body black, hoary beneath. Eight inches long; tail same length. 
emericanus, (american rat,) tail long, scaly; head long; nose pointed ; upper jaw longest ; ears large, naked. About 8 inches long, or smaller. musculus, (house-mouse, tail long, nakedish ; forefeet four-toed, hind feet five-toed, thumb without a claw. 3 inches long.

sylvaticus, (field-mouse,) tail long, scaly; body yellowish-brown, white beneath, breast yellowish. Var. albus, entirely white. messorius, (harvest mouse, tail long, scaly ; body rusty-brown, belly white, colours divided by a straight line. virginianus, (pasture mouse, tail all hairy, thick at the base, long, tapering; body whitish or white, nose black.

amphibius, (water rat,) tail middle length ; ears hardly above the fur ; feet three-toed, with the appearance of a fourth. Sometimes hind feet five-toed. Dark or blackish. Body 7 inches long, tail three.

See MS. P.

8-12. Musca. Spec. about 530. domestica, (house-fly,) with two short feelers; sucker with a single bristle without sheath; hairy, black; thorax with five pale lines ; abdomen tessilate, pale at the base beneath. cadaverina, (carrion eater, body polished; thorax blue; abdomen green. Feelers and suckers like domestica.

mortuorum, (death fly, epidemic fly, thorax black; abdomen green bronze; legs black ; thorax with a few faint lines. Feelers and suckers like domestica. 
futris, (maggot fly,) black ; wings white with a black rib. Feelers and suckers like domestica. Deposits eggs, which become the common white skipper.

See Ms. P.

2-2. Muscicapa. Spec. 97.

striata, (fly-catcher,) green-ash ; back streaked with black, yelluwish beneath; chin and sides of the neck spotted with brown; three outermost tail-feathers tipped with white. 5 inches long.

canad'ns's, (northern fly-catcher,) cinereous, paleyellow beneath; lores yellow; crown spotted with black. 4 inches long.

atra, (bee-catcher,) olive-ash ; breast cinereous ; belly whitish-yellow ; head, tail and quillfeathers black, the secondaries at the edge and outmost tail-feathers on the outer webs white. See MS. P.

8-9. Mutilla. Spec. 38.

curopea, (wingless fly, black ; thorax rufous : segments of the abdomen with white margins. See MS. P.

$$
\text { 9-3. Mya. Spec. about } 60 .
$$

Remarks. This genus and Mytilus have been cut up into several new genera. Unio is the prin. cipal genus taken from Mya. Alasmadonta, Monodonta, \&c. are proposed. But the unsettled state of the numerous proposed subdivisions, even among some of the best zoologists of our times, demonstrates the absurdity of the modern rage for innovation. Perhaps future naturalists will fix the boundaries of these subdivisions on definite 
grounds; it will then be early enough to adopt them. I have retained the original name, and made sertions of the genera, which appear to be unsettled.

All the species, here described, are found in our fresh waters, excepting the first. Taken from Say in Nicholson, and Barns in Silliman.

Sec. A. Shell without cicatrices.

margaritifera, (false pearl oyster,) shell ovate, a little contracted in the middle of the thinner margin ; primary tooth of the hinge conic ; protuberant part near the hinge decorticated.

Sec. B. Shell with three deep cicatrices. Shell transverse; hinge with a strong irregular tooth and two lateral ones. UN10 of Bruguieres. cornuta, (horned muscle,) shell sub-spheroidal, divided longitudinally by a regular row of large distant tubercles. Shell thick, rounded behind ; cardinal teeth furrowed; pearly-white and irridescent within. Dimensions an inch and threefourths by an inch and a half. verrucosa, (warted muscle,) shell subtruncate before, irregularly tubercled ; the tubercles transversely cumpressed; brownish-red within. Subquadrangular, thick, rounded behind; beaks elevated and recurved; cardinal teeth crenate or furrowed ; cavity of the beaks deep. Dimensions about two inches by one and two thirds.

nodosa, shell subquadrangular, emarginate before, knotted, ridgy, corrugated; lateral tooth terminating abruptly ; shell thick and heavy ; beaks distant, eroded; hinge margin straitish ; 
epidermis horn-colour ; surface irregularly corrugated and tubercled; tubercles largest near the center of the disk, and often eroded ; cardinal teeth furrowed and crenulated ; lateral teeth short, thick, crenate. Dimensions three inches by two and a half.

tuberculata, shell long-ovate, surface corrugated, undulate-tubercled, ribbed ; disks compressed, base falcate; shell thick and rugged; beaks flat near the posterior end ; hinge-margin straitish ; epidermis dark brown or horn-colour ; elongated tubercles are thickly scattered over the surface ; cardinal teeth crenated, lateral ones long and striated; pearly white, with irregular greenish spots within. Dimensions about four inches by two and a fourth.

rugosa, shell broad-ovate; surface wrinkled tuberculated, ribbed, undulated ; disks swelled ; base falcate; shell compressed and thin before; beaks slightly elevated ; hinge-margin compressed, keeled ; epidermis dark brown, pearly white under it ; surface rough and scaly, wrinkled transversely and undulated lengthwise. Dimensions two inches and a quarter by three. crassa, (thick-shell muscle,) shell varying in form and surface, very thick and heavy ; epidermis horn-colour, different shades of brown and black; beaks carious, often much eroded, pure pearly or silvery white. Dimensions sometimes four and a half inches by three. purpurea, (purple muscle,) shell suboval, and somewhat compressed; smaller wrinkles between larger ; colour dark-brown; beaks carious, not prominent, near to one end ; often waxyellow under the epidermis; reddish purple 
within, varied with green; no cavity under the beak. Dimensions two abd a half inches by one and two thirds.

ovata, shell but middling, subovate, convex, not remarkably thick, horn-colour, not radiated, flattened and fuscous on the anterior margin ; beaks decorticated and placed nearer central ; boss prominent ; pearly within ; cavity of the beak capacious; primary teeth very oblique, almost parallel to the posterior margin and much compressed. Dimensions four inches by three.

cariosa, shell but middling thick, long forward, short back of the beaks; olive-green, sometimes radiated with green and with interrupted wrinkles in longitudinal rows ; beaks somewhat prominent, distant, carious, wax-yellow beneath the epidermis ; concavity bluish-white ; teeth often subconic and crenate. Dimensions two inches and a quarter by one and a half. ochrocea, shell thin, fragile, translucent, subovate; hinge margin straitish ; pale-olive or orange; often with green wrinkled radii ; anterior margin wrinkled ; beaks decorticated and near, with two or three concentric undulations; bluishwhite or yellowish within, reddish near the base ; teeth very oblique and much compressed. Dimensions an inch and a quarter by an inch and three quarters.

nasuta, shell thin, oblong, compressed, beaked, horn-colour or fuscous, wrinkled, with green radiations ; bluish-white within ; teeth crenate; scarcely any back-cavity. Dimensions about one inch by two and a half. 
alata, shell moderately thick, subtriangular, generally gaping at the back part of the base, fus cous, wrinkled; beaks near the back part, decorticated ; base straitish ; hinge-margin oblique with a winged process ; red-purple within; teeth crenate. Dimensions five inches and a half by three and three fourths.

cylindrica, shell very thick, subcylindric, emarginate forward ; pale horn-coloured and greenish; hinge-margin undulated obliquely across the wrinkles ; rough on each side; beaks broad and prominent ; pearly within; teeth thick and crenate; cavity of the beaks very deep. Dimensions three iuches and a quarter by one and

a quarter.

undulata, shell subrhombic, with undulations, which radiate from the beaks; shell thick, obtusely rounded behind ; hinge -margin somewhat winged ; epidermis blackish.

plicata, shell subquadrangular, tumid, sinuous before with distant oblique folds ; hinge-margin elevated, compressed, keeled; shell thick. undata, shell subtriangular, very tumid, undulated ; lateral teeth two in each valve; shell thick, beaks projecting backwards ; epidermis horn-colour approaching yellowish-green ; teeth deeply furrowed and crenate, lateral teeth two in each valve.

cllipticu, regularly oval, thick, convex, glabrous ; beaks depressed ; teeth elevated, triangular, striated; shell long before and short behind; epidermis yellowish-brown, obscurely rayed; teeth deeply divided, finely striated; pearly white, iridescent or flesh-colour within. Dimensions about four inches by two and a half. 
carinata, shell oblong-oval, two-angled before, rayed, hinge-margin strait, compressed, keelform ; teeth finely striate; shell elongated transversely ; epidermis greenish-yellow with broad dark-green rays ; surface glabrous ; white, iradescent within. Dimensions about three inches by two.

pralonga, shell much elongated transversely, nar* row, thick, tumid, beaks flat ; lateral tooth long, thin ; purple within ; epidermis blackish. brown with fine interrupted wrinkles in longitudinal rows. Dimensions about three inches by one and a quarter.

gibbosa, shell elongated transversely, thick gibbous; lateral toulh very thick, incurved; purple within ; shell thick and heavy, suddenly narrowed so as to appear beaked before, narrow and rounded behind, so as to appear subcylindric ; epidermis blackish-brown finely striated and deeply wrinkled transversely; purple within; lateral tooth very thick. Dimensions about four inches by two.

cuneata, shell ovate, wedgeform, thick, gibbous ; disks tumid, anterior lunule furrowed ; lateral tooth thin ; purple inside ; shell elongated, subtriangular, thick and heavy; beaks low and distant ; epidermis blackish-brown, subferruginous, surface in fine wrinkles. Dimensions three inches and three quarters by two and a quarter.

radiata, shell broad-ovate, thin, finely striated, glossy rayed; bluish-white within, or tinged with red; shell with the anterior side broad thin, fragile; beaks slightly elevated and ap 
proximated ; epidermis greenish-yellow or olive-brown, with dark-green rays finely striated transversely ; surface smooth and shining. Dimensions about one inch and a half by two and a half.

mucronata, shell ovate, broader behind ; base compressed, falcate ; beaks small, elevated, acute ; purple within ; anterior lunule long, posterior one small ; epidermis horn-colour and obscurely rayed, smooth. Dimensions one inch and a quarter by two and a quarter.

inflata, shell oval, thick, tumid ; beaks broad obtuse behind, wedge-form before; pearly-white within; epidermis yellowish-green, rayed. Dimensious one inch and three quarters by three and a quarter.

ventricosa, shell large, thick, triangular, ovate, convex ; bosses large, round, prominent ; beaks recurved ; cavity capacious ; epidermis yellowolive, with green rays; surface smooth and shining ; pearly-white within. Dimensions about three inches by four.

siliquoidea, shell long-ovate, subcylindric, thick, regularly rounded, rayed; beaks elevated ; cavity small ; inside white; epidermis yellowisholive, rayed with distant dark-green lines. Dimensions two inches by three and a quarter. plana, shell rhomb-oval ; thin, beaks depressed ; disks flattened compressed ; teeth slightly elevated, smooth; epidermis brown-yellow, deeply wrinkled Dimensions two inches and three fourths by four and three fourths. triangularis, shell triangular, gibbous-inflated, rayed, gaping; anterior slope flattened, ribbed, can*19 
cellate, white within ; epidermis yellowishgreen, rayed with dark-green, finely striate transversely. Dimensions three fourths of an inch by an inch and a quarter.

gracilis, shell triangular-ovate, very thin and fragile, hinge-margin elevated into a wing; valves connate ; ligument concealed ; epidermis seagreen, obscurely radiated; bluish-white within and tinged with violet. Dimensions two inches and a half by four.

parva, shell oblong-ovate, small, convex, sides rounded; beaks slightly elevated; pearly-white and iridescent within ; epidermis brownish; very brilliant within. Dimensions one inch by two thirds of an inch.

Section C. Hinge with prominent cardinal teeth, but without lateral ones ; posterior cicatrice compound. Alasmodonta of Say.

arcuata, shell ovate, elongated transversely, thick ; base arched, ligament elevated, beaks depresserl, cicatrices rough ; epidermis brownish-black ; surface smooth in the young state, eroded and scabrous when old; teeth two in the right and one in the left valve; bluish-white within. Dimensions two inches by four.

rugosa, shell oblong-oval, anterior side with deep diverging folds ; epidermis chesnut-brown with a silky lustre; surface of the fore part folded in a pinnate form ; cicatrices smooth ; pale fleshcolour in the center within, pearl white on the margin with a dark narrow border. Dimen sions two inches by three and a half. complanata, shell ovate-quadrangular, hinge-margin elevated into a large wing; valves connate : 
ligament concealed ; epidermis brown, glossy, surface w rinkled and striated transversely; bluish-white and iridescent within. Dimensions three inches by five.

See MS. P.

8-5. Mycetophagus. Spec. 14. quadrimaculata, thorax and shells black, striate, the latter with two rufous spots; body rufous. See MS. P.

\section{2-5. Mycteria. Spec. 3.}

americana, (jabiru,) white ; quill and tail-feathers purplish-black. 5 or 6 feet long.

See MS. P.

\section{1-4. Mroxus. Spec. 4.}

muscardinus, (dormouse,) body tawny ; throat whitish; hind thumbs without claws. 3 inches long.

See MS. P.

8-8. Mrrmelon. Spec. 16.

formicarius, (lion-ant,) wings clouded with brown, with a white marginal spot behind. See MS. $P$.

1-5. Mrrmicophaga. Spec. 7. jubata, (ant-eater,) four toes on the fore feet, five on the hind feet; tail bushy.

See MS. $P$.

9-3. Mrtilus. Spec. about 70.

Sec. A. Compressed and slightly eared. inargaritiferus, (pearl oyster, mother-of-pearl,) shell flattened, suborbicular, with a transverse base imbricate with toothed tunics. 
Sec. B. Convex or ventricose. Shell transverse; hinge simple, destitute of teeth; shell with three obsolete muscular impressions. Anodonta of Bruguieres.

cataractus, (toothless muscle,) shell thin, fragile, translucent, oblong-oval, convex; covered with a radiated olive-green epidermis ; pearly within; beaks nearly central ; front margin brown. Length about two inches and a half, breadth four and a half.

marginatus, shell very thin, fragile, somewhat compressed, translucent, subovate ; epidermis olive-green, paler on the disk and greener before; anterior margin fuscous ; beak nearer to the posterior end ; bluish-white within, edges whitish.

See .MS. P.

\section{N. \\ 5-3. NaIS. Spec. 10.}

proboscidea, with single lateral bristles and very long proboscis. Three-fourths of an inch long. In clear water an inch long. serpentaria, body serpentine, with red spiral intestines and triple black collar. In stagnant water. An inch long.

vermicularis, without lateral bristles ; chin bearded. In stagnant water. One-sixth of an inch long.

See MS. $P$.

9-4. Nautilus. Spec. 31.

pompelius, (nautilus, aperture of the shell cordate, with obtuse and swooth whorls. Pearly within.

See MS. $P$. 
8-5. Necydalis. Spec. 39.

major, (carrion eater,) shells ferruginous, without spots; antennse short; head black; wings longer than the body.

see MS. P.

8-7. Nera. Spec. 14.

cinerea, (water scorpion,) tail ending in two bristles, half as long as the body; body ovate, brown.

See MS. P.

5-2. Nereis. Spec. 30.

oroctiluca, body blue-green, with twenty-throe seg: ments; scarcely visible to the naked eye. In sea.

See MS. P.

9-4. Nerita. Spec. 76.

glaucina, shell smooth, glossy ; spine somewhat obtuse; umbilicus partly closed by the pillar lip, which is gibbous and two-coloured. See MS. P.

8-7. Notonecta. Spec. 17.

striata, (boat $f y$, ) upper wings pale brown, with. numerous dots and streaks of dark-brown. All the species swim on the back. See MS. P.

2-4. Numidia. Spec. 4.

meleagris, (guinea-hen,) caruncles at the gape doubled; no gulor fold ; breast white. Sometimes the whole body is white ; but it is generally speckled. About eighteen inches long.

see MS. P. 


\section{o.}

4-1. Odontognathus. Spec. 1. aculeata, compressed; lower jaw longest. See MS. P.

\section{8-12. OEstrus. Spec. 12.}

bovis, (gad-fly,) wings brown without spots; $a b$ domen with a black band in the middle, and orange-yellow hairs at the tip. Deposites its eggs under the skin of cattle, which causes them to run and bellow when in the larva state. equi, (leg nitter,) wings whitish with a black band in the middle and two dots at the tip. Deposites its eggs on the hairs of horses' legs in the the summer months.

hemorrhoidalis, (lip nitter, wings brownish without spots ; abdomen black, the base white and fulvous at the tip. Deposites eggs on the lips of horses.

veterinus, (throat nitter, bot-fly,) wings without spots; body ferruginous; sides of the thorax and base of the abdomen with white hairs. A little smaller than the leg nitter. Deposites eggs under the skin of the throat of horses in September.

Remarks. The three last species are the nitters so well known in this country ; particularly the leg and throat uitters. It is the received opinion that the nits on the legs of horses, are taken into the mouth of the horse, conveyed into the intestines, and at length become the bot larva. This is a very extravagant conjecture and requires proof. 
From some observations which I have made, $I$ am inclined to the following opinion ; but I confess it wants farther proof. That the eggs deposited under the skin, near the inner angle formed by the horse's head and neck, are the only eggs or nits, which produce the bot larva. That when they pass into the larva state, they are very small, and make their way directly into the alimentary canal, and soon grow to size sufficient to injure or destroy the horse. This hypothesis is more conformable to analogy, if we study the habits of other animals, not intestinal, which inhabit the bodies of large animals, while in the larva state.

If on further observation this opiniou should be established, horses may be saved from the mortal malady, called the bots, by fastening a piece of oil-cloth under the throat, for three or four weeks; commencing on or about the last week in August. As my observations are confined to one year, $I$ would invite all students in zoology to make careful observations on this insect; and, if possible, to hatch out a bot larva, and see whether the veterimus is, or is not, the only species which causes such destruction among the most valuable of all animals.

See Mis. P.

\section{9-1. Onchidium. Spec. 1.}

typha, borly convex above, ash-colour, tubercled ; flat and smooth beneath. An inch long, or more when creeping.

Sec $\mathbf{M}>$.

6-2 to 5. Oviscus. Spec. 43. armadillo, (sowbug, feelers unequal, hind ones 
longer; antennæ filiform; tail obtuse entire ; body of ten segments, with white edges. Under stones.

assellus, (wood-louse,) feelers and antennæ as in the last; tail obtuse, with two simple styles. In walls and rotten wood. See MS. P.

\section{4-3. Ophicephalus. Spec. 2.}

gunctatus, body and beak entirely covered with large scales; gills 5-rayed; body subcylindric. See MS. P.

\section{4-1. Ophidium. Spec. 4.}

barbatum, lower jaw with four cirri. A foot long. imberba, jaws without cirri ; tail bluntish. See MS. P.

\section{2-2. Oriolus. Spec. 51.}

phoeniceus, (oriole, red-shouldered blackbird,)

black; wing-coverts tawny. Sometimes with red shoulders.

ferrugineus, (rusty blackbird,) black ; edge of the wings rusty; head and neck purplish-black. Seven inches long. niger, (corn blackbird,) totally black.' About 9 inches long. Female greenish-brown. See MS. P.

4-5. Ostracion. Spec 12.

triqueter, (trunk-fish,) body triangular, unarmed. See Ms. P.

9-3. Ostrea. Spec. 137.

Section A. Valves furnished with ears and radiate. Pecten of Bruguires.

maxima, (scallup,) ears equal ; shell with about 
14 rounded and longitudinally striate rays. 5 inches long.

jacobæa, having 14 angular rays.

Section B. Rough, and generally plaited on the outside. The proper Oyster.

edulis, (common oyster,) shell suborbicular, rugged, with undulate imbricate scales; one valve Hat, entire. Extremely variable in form, size and colour.

plicatula, (fan-shell oyster,) shell with longitudinal wrinkled plaits; the lower valve a little less and fiatter. Generally cinereous with a mixture of violet, sometimes bluish-white. See MS. P.

\section{2-5. Otis. Spec. 11.}

iarda, (bustard,) wave-spotted with black and rufous, whitish beneath; head (of the male) and throat each side crested. 4 feet long. See MS. P.

1-\%. Ovis. Spec. 4.

cries, (sheep,) horns compressed, lunate. See MS. P.

Varieties.

Hornless. Horns none or mere rudiments ; tail reaching as low as the knees.

Black-face. Horned; tail short, wool short and coatise.

Merino. Horns spiral and extended outwards: wool fine and plentiful. This variety secretes so much oily matter upon the wool that muche dust adheres to it.

See MS. P. 


\section{P.}

2-5. Palamedea. Spec. 2.

cornuta, (screamer,) wings with two spines at the bend ; front horned. 3 feet long.

See MS. $P$.

\section{1-6. Palceotherium. Spec. 5.}

equinum, (extinct species,) bones in some particulars resembling those of the horse.

See MS. $P$.

8-8. Panorpa. Spec. 9.

communis, wings of equal length, spotted with black.

See MS. $P$.

$$
\text { 8-10. Papilio. Spec. } 1272 .
$$

Remarks. The larva, or caterpillars, liare twelve eyes on the head (or rather twelve lenses, ) body in twelve segments, with nine spiracles on each side, and is generally beset with prickles. The caterpillar becomes a chrysalis or pupa, which is scarcely capable of motion; and is distinguished from that of the phalæra genus, by never being provided with a web. It is toothed, often having golden spots, and is suspended by its posterior extremity.

All the species fly in the day time only; and when sitting have their wings erect. For convenience in analyzing, Linneus distributed butterflies into five divisions or families. See Gore's Blumenbach, p. 202. The larva of this genus are mostly harmless.

1. Div. Equites, (knights,) upper wings louger from the posterior angle to the tip, than to the 
base; antennæe often filiform. This division is subdivided into 1. Trojans, which are generally black, with sanguineous spots on the breast: 2. Greeks, which have an ocellate spot at the angle of the tail, and no sagguineous spots on the breast.

See $M S$. $P$.

2. Div. Haliconir, wings narrow, entire, often naked or, semi-transparent; upper ones oblong; lower ones short.

See MS. $P$.

3. Div. Danar, wings very entire. This division is subdivided into 1. Candidi, with whitish wings : 2. Festivi, with variegated wings.

See MS. $\boldsymbol{P}$.

4. Div. Nymphales, wings denticulate. This division is subdivided into 1. Gemmata, having wings with ocellate spots: 2. Phalerati, having wings without ocellate spots.

See MS. $P$.

5. Div. Plebeir, small ; the larva often contracted. This division is subdivided into 1. Rurales, having wings with obscure spots; 2. Urbicolæ, having wings mostly with transparent spots. See MS. $P$.

Remarks. Not only the sections and subsections, have historical names, but the genera are named upon the same plan. Those which fall under the subsection, Trojans, for example, have Trojan names; under Greeks, Grecian names. A vast and beautiful genus.

2-2. Paradisea. Spec. 12.

apoda, (paradise bird,) chesnut; neck gold-green 
beneath ; feathers on the sides longer than the body ; two middle tail-feathers very long, bristjy.

See MS. P.

14-2. Paramecium. Spec. 7.

aurelia, compressed, longitudinally plaited towards the forepart, acute behind. In ditches and infusions.

Sce MS. P.

2-5. Parra. Spec. 16. dominica, (jacana,) claws moderate ; legs yellow. . See MS: $P$.

\section{2-2. Parus. Spec. 31.}

americanus, (titmouse,) bluish ; temples, breast and back yellowish ; flanks purplish. ater, (colemouse, head black; back cinereous ; hind-head and breast white. Sec MS. $P$.

9-4. Patella. Spec. 239. Section A. Having an internal lip.

fornicata, (limpet,) shell oval, obliquely recurved behind; lip placed behind and concave. On oysters, \&c.

Section B. Having no internal lip.

fissura, (knee-pan,) shell oval, conic, with reticulate strix, cleft on the fore part ; crown recurved.

See MS.P.

8-5. Pausus. Spec. 5.

ruber, reddish; thorax jagged before.

See MS. $P$. 


\section{2-4. Pavo. Spec. 4.}

cristatus, (peacock, head with a compressed crest ; spurs solitary.

See MS. P.

13-1. Pedicellaria. Spec. 3. globifera, head spherical; neck none. see MS. P.

8-3. Pebiculus. Spec. 65.

humanus, (louse,) abdomen lobed, cinereous.Found on the heads of children; also on the heads and clothes of uncleanly full-grown persons.

See MS. P.

4-6. Pegasus. Spec. 3.

draconis, (dragon-fish,) snout conic ; fin-rays simple. 3 inches long.

See MS. P.

2-6. Pelecanus. Spec. 31.

Section A. Bill without indentations.

onocrotatus, (pelican,) white, with a pouched gullet.

carbo, (corvorant,) tail rounded; body black;

head subcrested. 3 feet long.

graculus, (shag, crane bird,) tail rounded; body

black, brown beneath ; tail-feathers twelve.

Section B. Bill indented or serrate.

bassanus, (gannet,) tail wedge-form ; body white; bill and primary quill-feathers black; face blue. Sce MS. R. 


\section{2-4. Penelope. Spec. 4.}

cristata, (guan, curassow,) head with an erect crest ; temples violet.

See MS. $P$.

13-2. Pennatula. Spec. 18.

phosphorea, (shining sea-pen,) stem fleshy, with a rough midrib and imbricate ramifications.

See MS. $P$.

4-3. Perca. Spec. 60.

Section A. Dorsal fins two, distinct.

Fiuviatilis, (river perch,) second dorsal fin with 16 soft rays. Sometimes two feet long.

americanus, (red perch,) red ; second dorsal fin with 13 rays. In brackish water.

labrax, (basse, second dorsal fin with 14 rays :

back dusky, tinged with blue; belly white. Body shaped like a salmon.

Section B. Dorsal fin single; tail undivided. marina, (sea perch,) red, with transverse dusky lines on the sides; gill-covers with a black spot; dorsal spines fifteen. A foot long. nobilis, body silvery, with eight brown bands.

Section C. Dorsal fin single; tail forked.

cernua, (ruffe,) dorsal fin 27-rayed, spines 15. 6 inches long.

nigra, (black.fish, ) body narrow, with small scales. 15 inches long.

See MS. $P$.

4-6. Petromyza. Śpec. 4. marinus, (sea-lamprey,) mouth papillose withiu; 
second dorsal fin distinct from the tail. 3 feet long.

fuviatilis, (river-lamprey,) second dorsal fin angulate. A foot long.

brancialis, (dwarf lamprey, second dorsal fin linear; mouth lobate. 6 inches long. Sce MS. $P$.

2-4. Phasianus. Spec. 15.

gallus, (hen,) comb on the crown, and two compressed wattles on the chin; ears naked; tail compressed, erect.

\section{Varieties.}

Crested hen. Crown with a thick downy crest. Darking hen. Feet 5-toed, two behind. Frizzled hen. Feathers all turned contrary.

Persian hen, Rumpless hen. Destitute of rump. and tail-feathers.

Creeper. Legs very short.

Banta hen. Shanks feathered, small.

Turkish hen. Colours curiously variegated.

Paduan hen. Body twice as large as common hen. Negro hen. Having black crest, wattles and chin. Crowned hen. Having a tuberous crown.

Horned hen. Having a crown so divided as to appear like horns.

Silk hen. Feathers resemble hairs; large. colchicus, (pheasant,) rufous ; head blue ; tail wedge-form; cheeks papillose. Colour various. See NS. $P$.

2-6. Pheton. Spec. 3.

cthereus, (tropic bird,) white; two middle tailfeathers black at the base ; bill red,

See MS. $P$. 
8-10. Phaldena. Spec. $15 \% 1$.

Remarks. This is the most extensive genus among insects. The larva are mostly hairy, and in many other particulars resemble those of the butterfly. They generally occupy a silky bag, when in the crysalis state, which they previously prepare from a tenaceous fluid contained in two pouches, placed along the back, beneath the stomach. This fluid they spin into very fine threads, by means of a tube placed behind the mouth. These constructions are remarkable in some instances, for their apparent artificial formation, and in some, (as the silk worm, for their great utility. See Gore's Blumenlach, p. 207. The larva of this genus prey voraciously on the leaves of plants, and are thus more injurious to fruit trees, than any other genus. All the species fly in the evening or night only.

The following are the divisions into which the species of this genus are distributed. Some alterations of the Linean divisions are here adopted from the improvements of Gmelin, Fabricius, \&c.

1. Div. Bomвxx, antennæ filiform ; feelers two, compressed, refiected ; tongue short, membranaceous, obtuse, bifid ; larva 16-footed, often hairy ; chrysalis pointed at the tip. Wings either, 1. expanded ; 2. reversed ; 3 . deflected ; 4. incumbent; or 5, convolute. A distinct genus, Bombyx, is made of this section. It includes about 280 species.

Ste MS. $P$.

2. Div. Geometra, antennæ filiform ; feelers cylindrical ; tongue projected, membranaceous, setaceous, bifid; larva 8 to 10 -footed, 6 of which 
are pectoral, 2 caudal, and sometimes 2 subcaudal ; chrysalis pointed at the tip. 1. Antennæe pectinate ; 2. setaceous; 3 . the wings are forked and connivent. Genus Phalæna of Fab. Contains 430 species.

See MS. $P$.

3. Div. Noctua, antennæ setaceous ; feelers compressed, hairy, the tip cylindrical and naked; tongue projecting, horny, setaceous, bifid ; larva 16-footed; chrysalis pointed at the tip. 1. Wings expanded; 2. flat incumbent, with a smooth thorax ; 3. wings flat incumbent, with a crested thorax ; 4. wings deflected, with a smooth thorax; 5. wings deflected, with a crested thorax. This division contains 400 species.

See MS. $P$.

4. Div. HyвLæA, antennæ setaceous ; feelers projecting, compressed, dilated in the middle; lip projecting, acute. This division contains 6 species.

See MS. P.

5. Div. Hepialus, antennæ moniliform; feelers two, reflected, hairy, between which is the rudiment of a bifid tongue; larva 16 -footed; feeding on the roots of plants ; chrysalis folliculate, cylindrical, and pointed at the tip. This division contains 10 species.

See MS. $P$.

6. Div. Cossus, antenna short, filiform ; feelers two, very short, cylindrical, reflected; having no spiral tongue. This division contains 6 species. 
7. Div. Pyralis, antennæ filiform ; feeler's two, equal, almost naked, cylindrical at the base, the middle dilated into an oval, and subulate at the tip ; tongue projected, setaceous, bifid ; wings very obtuse and slightly curved at the exterior margin ; larva 16-footed, and rolling up the leaves to which it attaches itself. This division contains 183 species. It is the genus Tortrix of Grmelin.

See MS. $P$.

8. Div. Tinea, antennæ setaceous ; feelers four, unequal ; larva found in houses among linnen and woollen clothes and furniture, in which it eats holes. This section contains 190 species. See MS. $P$.

9. Div. Alucita, antennæ setaceous; feelers two, divided to the middle; the inner divisions very acute. This is the genus Tinea of Gmelin. It contains 53 species.

See MS. $P$.

10. Div. Prerophorus, antennæ setaceous ; feelers two, linear, naked; tongue exsert, membranaceous, bifid; wings fan-form, divided down to the base, and generally subdivided as far as the middle ; larva 16-footed, ovate, hairy ; chrysalis naked, subulate at the tip. It is the genus Alucita of $G$ melin. It contains 13 species. See MS. $P$.

7-2. Phalangium. Spec. 19.

Sec. A. Mouth with a conic tubular sucker. grossipes, (sea graybeard,) feelers four, the upper ones chelate ; body minute, cylindric, glabrous ; 
shoulders tuberculate; legs very long; body dirty red. Enters muscle shells. Ealaenarum, (land greybeard,) feelers two; body ovate, red on the back.

See MS. P.

Sec. B. Mouth without a sucker.

opilio, (shepherd, common graybeard,) abdomen ovate, grey, whitish beneath ; feelers projecting, incurved. Wanders about at night. cornutum, (spot-greybeard,) abdomen depressed ; mandible conic, ascending; feelers resembling legs; body grey-brown above with a darker rhombic spot in the middle.

See MSS. P.

\section{8-6. Phasira. Spec. 1.}

rossin, (spectre) without wings, excepting the mere rudiments, green, yellowish or dark ashcolour ; antennæ very short.

See MS. P.

\section{1-3. Proca. Spec. 19.}

barbata, (seal,) head smooth, without external ears; body blackish. Sometimes twelve feet long.

vitulina, (common seal, sea calf,) head without external ears ; neck smooth ; body brown. Sleeps on stones projecting above water. See MS. P.

2-5. Phœnicopterus. Spec. 2.

nuber, (red flamingo,) quill-feathers black; colour passing from ash to scarlet as it advances in age. See MS. P. 


\section{9-2. Pholas. Spec. 12.}

dactylus, (pierce-stone, shell oblong, with reticulate subspinous striæ on the upper part. Five inches long. Shines by night. See MS. P.

8-8. Phryganea. Śpec. 55.

bicaudata, (water-moth,) wings reticulate, brown ; body brown with a yellowish line on the head and thorax. Larva in water inclosed in tubes made of sand, scraps of wood, \&c.

See MS. P.

12-2. Physsophora. Spec. 3.

hydrostatica, oval ; with numerous lateral 3.lobed vesicles, open outwardly ; middle intestine and four longer tentacula red. Resembles a Medusa.

See MS. P.

\section{1-8. Physeter. Spec. 4.}

macrocephalus, (white whale, cachelot,) no dersal fin; spiracle on the neck. Sometimes blackish. About 60 feet long.

See MS. P.

2-2. Phyтotoma. Spec. 1.

rara, (ra-ra,) bill thick, indented ; borly duskyash above, paler beneath. See MS. P.

2-2. Prcus. Sipec. 58.

pileatus, (great woodpecker, black ; crest red ; temples and wings spotted with white. 12 to 18 inches long.

hirundinaceus, (red-cap woodpecker,) black ; cap 
scarlet; shoulders dotted with white. Five and a half inches long.

erythrocephalus, (red-headed woodpecker,) head wholly red; wings and tail black; belly white. 6 to 9 inclies long.

major, (spotted woodpecker, variegated with black and white; vent and hind-head red. 9 inches long. See MS. $P$.

\section{9-3. Prnna. Spec. 18.}

muricata, (sea-wing,) shell striate, with concave, ovate, acute scales. 3 to 9 inches long. See Mj. P.

2-2. Pipra. Spec. 31.

rupicola, (manakin, rock-hen,) crest erect, edged with purple ; body saffiron-colour; tail-feathers truncate. 10 inches long. See MS. $P$.

\section{1-2. Planaria. Spec. $4 \%$.}

fusca, (eyed worm,) hlack-brown with a semipellucid whitish spot above the tail. Resembles a bloodsucker.

See MS. P.

$$
\text { 1-5. Platy pus. Spec. } 1 .
$$

anatinus, (duck-bill,) body depressed, covered. with soft fur, dark above, lighter beneath. See MS. P.

\section{2-5. Platalea. Spec. 3.}

leucorodia, (spoonbill,) body white ; chin black; hind-head subcrested. 2 feet long. See MS. P. 


\section{4-4. Platystachus. Spec. 3.}

verrucosus, having a very short tail.

See MS. P.

4-3. Pleuzonectes. Spec. 29.

Sec. A. Both eyes on the right side of the head. hippoglossus, (hollibut,) body perfectly smooth; tail lunate. All sizes. Specimens have weighed 400 pounds.

Alessus, (flounder,) lateral line rough ; short spines on the right side of the fins. Largest weigh five or six pounds.

solea, (sole,) body oblong, rough ; upper jaw longer. Sometimes two feet long.

Sec. B. Eyes both on the left side of the head.

maximus, (turbot,) body rough ; fins yellowish with black points and spots. Sometimes weighs 30 pounds.

See MS. P.

2-2. Plotus. Spec. 3.

anhinga, (darter,) head smooth ; belly white. Near three feet long.

See MS. $P$.

8-2. Ponura. Spec. 32.

signata, (common springtail,) subglobular, brown; abdomen with fulvous spots at the sides; antennæ as long as the body.

viridis, (buckwheat springtail,) subglobular, green with a yellowish head.

See MS.P. 


\section{4-4. Polynemus. Spec. 4.}

quinquarius, appendages five, longer than the body.

See MS. P.

$$
\text { 4-4. Polypterus. Spec. } 1 .
$$

bichir, sea-green, covered with long scales ; dorsal fins 16 or more.

See MS. $P$.

2-6. Procellaria. Spec. 24.

obscura, (petrel,) black, white beneath ; membrane connecting the toes tawney. See MS. P.

2-5. Psophia. Spec. 2.

crepitans, (trumpeter,) black ; back grey ; breast shining blue-green; orbits naked, red. 20 inches long.

See MS. $P$.

3-4. Proteus. Spec. 1.

limodracus, (mud-dragon,) spotted, having a purple ruffle, or suit of gills, around the neck. After reading Dr. Mitchell's article on the subject in Silliman's Journal, the article in Cuvier, and in Long's Expedition, I have not been able to find any settled specific name for the Lake Erie Proteus. I have therefore adopted one for our students, as we have two elegant specimens in our collection--one presented by Mrs. General Porter, and the other by Maj. Frazer, of Black Rock. The former is seven, and the latter fourteen inches in length.

See MS. P. 
2-3. Psitracus. Spec. 170.

macoa, (red parrot,) red ; quill-feathers blue above, rufous beneath ; feathers of the shoulders variegated blue and green ; cheeks naked, wrinkled. Between 2 and 3 feet long.

severus, (common parrot,) green ; cheeks naked ; quill and tail feathers blue, purplish beneath. Sometimes dusky-green ; front brown ; crown greenish-blue. About 17 inches long. See aMS. $P$.

9-1. Prerotrachia. Spec. 4. coronata, abdomen and tail furnished with fins; liead with a round perpendicular proboscis, and a coronet of ten spines on the front. See MS. $P$.

8-5. Prinus. Spec. 39.

pulsator, (death-watch,) feelers clavate; lip entire; subvillous, dusky, with irregular greybrown spots. Makes a ticking noise in 7,9 or 11 strokes at a time. Resides in old woorlen ceilings, furniture, \&c.

fur, (plant-thief, testaceous; thorax four-toothed; shells with two white bands. Very destructive to collections in Natural Histury.

See MS. P.

\section{8-4. Pulex. Spec. 2.}

iritans, (flea,) proboscis shorter than the body. Makes its way under the hair of logs, cats, \&c. and under the cloathes of men.

penetrans, (toe flea,) proboscis as long as the body; reddish-brown. Creeps into the toes, \&c. See MS. P. 


\section{R.}

4-6. RaJA. Spec. 19.

pastinaca, (sting ray,) body smooth ; tail with a long sharp spine, serrate on the forepart, and another on the back. Sometimes having two back-spines ; and sometimes the body is covered with spots. From one to two and a half feet long, and two-thirds or three-fourths as. broad.

See MS. P.

2-5. Rallus. Spec. 31.

crex, (rail, crake, wings rusty-red; mostly rus ty-red or rusty-grey or brown.

fiorzana, (gallinule, spotted rail,) two middle tailfeathers edged with white; bill and legs pale olive.

See MS. P.

3-4. Rana. Spec. about 40.

Section A. Body warty, puffed up; legs shorter. Toads.

bufo, (common toad,) body lurid and brown. Sometimes brown-olive with a yellowish-red band; sometimes spotted with green, \&c. rubeta, (rain toad,) vent obtuse; a yellowish line on the back; body beneath spotterl with black. From one to two inches long. Body pimpled, dirty yellow.

Section B. Body smooth, more oblong; legs longer. Frogs.

sipens, (croaking frog; green with numerous ocellate spots, surrounded with a yellowish ring. *21 
Four to six inches long. Leaps to a great distance; croaks loudly in the spring season. temporaria, (common frog,) back flattish, subangular; sometimes dirty-olive above, with large warty spots, and very large. esculenta, (eatable frog;) body angular; back transversely gibbous; belly emarginate. Body green with three yellow lines. The male croaks at evening.

Section C. Hind feet very long; claws lenticulated. Chirping toads.

arborea, (tree-toad,) body greenish-brown, or cinereous, granulate beneath ; feet cleft, having obicular flattened claws secreting an adhesive mucus.

boans, (croaking chirper,) body smooth with contiguous dots beneath ; feet palmate. See MS. P.

$$
\text { 8-8. Raphidia. Spec. } 2 .
$$

ophiosus, thorax cylindric; wings without spots. See MS. P.

2-5. Recurvirostra. Spec. 3. americana, (avocet,) head and neck reddish ; back black, white beneath. see MS. P.

2-3. Rhampastos. Spec. 17. viridis, (toucan,) green; belly yellow ; rump red. About fourteen inches long. see MS. P.

1-6. Rhinoceros. Spec. 2. snicornis, (one-horned rhinoceros,) one horn on 
the nose, growing from the skin, like the briar prickle from the bark.

bicornis, (two-horned rhinoceros, horns two. See MS. P.

2-6. Rhynchops. Spec. 1.

nigra, (skimmer,) blackish, white beneath; bill red at the base.

See MS. P.

5-1. Sabella. Spec. 25.

alveolata, (case-worm, ) with numerous parallel tubes communicating by an aperture, forming in the mass the appearance of honey-comb. Two or three inches long.

3-4. Salamandra. Spec. 11. palustris, (warted newt,) body blackish; sides speckled with white; belly orange, with irregular black spots. lacustris, (swamp newt,) black ; tail lanceolate; spotted with white, black, yellow or saffron. aquatica, (water newt, ) tail roundish, middle-size; brown or yellowish.

salamandra, (proper salamander,) tail roundish, short; body porous, variegated with black and yellow, also sometimes brown or white. A small variety is brown and has the tail considerably compressed.

4-4. Salmo. Spec. 56.

Seetion A. Body variegated; teeth apparent. salar, (common salmon,) upper jaw extending beyond the lower ; first dorsal fin cinereous, spotted. All lengths, even to six feet. 
trutta, (salmon trout,) body with black spots encircled with brown; pectoral fin with six dots; palate with three rows of teeth. From one to two feet long.

fario, (common trout, ) body with purple-red spots ; lower jaw a little longer. Sometimes it has violet spots above on a brown ground; sides whitish-yellow with red spots surrounded with white, and a brown area; white beneath. About a foot long and moves with great velocity. Palate with three rows of teeth.

Section B. Teeth scarcely visible or none.

lavaretus, (lavaret, gwiniad,) upper jaw longer ; dorsal fin fourteen-rayed.

otsega, (otsego bass,) jaws without teeth ; dorsal fin with nine softish rays over the ventral fins, also a second dorsal fin over the anal ; caudal fin forked ; lateral line obscure; under lip bifid ; iris of the eye silvery. From one to two feet long. A new species proposed by Doct. Clinton, senior.

See MS. $\boldsymbol{P}$.

$$
\text { 9-1. SEALPA. Spec. } 11 .
$$

natata, body marked at one end with a brown spot. See MS. $P$.

$$
\text { 4-3. Scarus. Spec. } 8 .
$$

sivulatus, jaws continuous, smoothed, serrate, with minute teeth at the edges.

See MS. $P$.

$$
\text { 8-5. Scarabeus. Spec. } 544 .
$$

siercorarius, (clock beetle,) thorax and head with. 
out horns or prickles ; black ; shield rhombic; crown a little prominent; shells grooved. melolontha, (tree beetle,) thorax and head without horns or prickles; testaceous ; thorax hairy; tail inflected; a triangular white spot at each incisure of the abdomen. Feeds on leaves of trees; while in the larva state it remains in the earth about three years, and is very destructive to corn and other vegetables.

See MS. $P$.

4-3. Scizna. Spec. 29.

cirrosa, upper jaw much longer, lower one with a cirrus.

See MS. $\boldsymbol{P}$.

1-4. Sciurus. Spec. 38.

vulgaris, (common squirrel, ears bearded at the tip ; tail colour of the back.

niger, (black squirrel,) ears not bearded ; body black. Sometimes the nose, neck and tip of the tail are white.

cinereus, (grey squirrel,) ears not bearded ; body cinereous; belly white.

striatus, (ground squirrel,) body yellowish, with five brown longitudinal stripes. A variety has the body pale with four stripes. Five and a half inches long.

volucellus, (flying squirrel,) having a membrane (made by a doubling of the skin) extending from the ears to all the legs and tail ; being attached to the forelegs as far as the toes, to the hind. legs as far as the ancles. By spreading this membrane, the squirrel sails through the aif 
from the top of a tree, descending at an angle of 45 or 50 degrees to the ground. See MS. $P$.

11-2. Scolex. Spec. 2.

pleuronectidis, head with four auricles, pellucid. In fish.

See MS. $\boldsymbol{P}$.

\section{2-4. Scolopax. Spec. 50.}

arguata, (curlew, bill arched, blackish; legs blueish; wings blackish with snowy spots. Nearly two feet long.

fusca, (dusky snipe, bill bent in at the tip; body black, waved with white; rump and wings white beneath. About a foot long. Migratory. grisea, (brown snipe,) bill, legs, wing-coverts and quill-feathers brown; head, neck and shoulders brown-ash, spotted with black; back and belly white. 11 inches long.

nigra, (black snipe,) bill and legs red; body black. flavipes, (yellow-shank snipe,) bill black; legs yellow; body whitish spotted with black; throat and breast varied with black and white ; belly andi tail-coverts white. 11 inches long. rusticola, (wood-cock, ) bill straight, reddish at the base; legs cinereous; thighs covered; head with a black band each side. 15 inches long. Body sometimes white or pale straw-colour or spotted. Head sometimes reddish; wings brown or white. minor, (little wood-cock,) bill straight; legs brownish ; front cinereous; hind-head black, with four transverse yellowish lines; chin white : 
body black and tawny above, yellow beneath.

11 inches long.

gallinago, (common snipe,) bill straight, tubercu-

late ; legs browu; body varied with blackish and tawney, white beneath; front with four brown lines. About a foot long.

glottis, (greenshank snipe,) bill straight, the lower base red; body snowy beneath; legs green. ish. 14 inches long.

calidris, (redshank snipe,) bill straight, red ; legs scarlet; secondary quill-feathers white. A foot long.

tatanus, (spotted snipe,) blackish with white spots, white beneath ; lines on the breast, and bands on the lateral tail-feathers blackish; legs red. Sometimes the wings have triangular white spots. See MS. P.

8-1. Scolopendra. Spec. 13.

lagura, (flat centipede,) legs twelve on each side ; body oval; tail with a white pencil of hairs; body hrown, head black.

forficata, (centipede,) legs fifteen each side ; body reddish-brown.

gigantea, legs seventeen each side; tail with two hooked styles.

electrica, legs seventy each side ; body linear. occidentalis, (thousand legs,) legs 123 each side. See MS. P.

\section{4-3. Scomber. Śpec. 22.}

scomber, (mackerel,) spurious fins five. From 1 to 2 feet lons.

See MS. P. 
2-5. Scopus. Spec. 1.

umbretta, (umbre,) body brown ; tail obscurely barred. Twenty inches long.

See MS. P.

4-3. Scorpena. Spec. 9.

parcus, cirri near the eyes and nostrils.

See MS. P.

7-1. Scorpio. Spec. 10.

amcricanis, (scorpion,) combs with fourteen teeth ; hands subciliate with filiform claws; body spotted with brown.

See MS. P.

9-1. Scyllea. Spec. 2.

pelagica, body fixed; four extreme arms alike, the middle ones papillose. Among sea-weeds.

See MS. P.

2-3. Scythrops. Spec.1.

psittaceus, back, wings and tail cinereous; feathers mostly with dark dusky tips. 2 feet long. see MS. P.

$$
\text { 9-1. Seria. Spec. } 8 .
$$

-fficinalis, (cuttle-fish,) body without tail or appendage, and surrounded by a margin ; tentacula (longer arms) two.

loligo, (calamary,) body subcylindric, subulate, furnished with a flattish sharp-edged rhombic membrane at the tail each side. From one to two feet long.

See MS. P.

2-1. Serpentarius. Spec. 1. vulturoides, (snake-eater,) body black; hind-head 
crested ; tail-feathers white at the tips; legs very long. 3 feet high.

Ste MS. P.

\section{5-1. Serpula. Spec. 48.}

spirorbis, (spiral shell-worm,) shell regular, spiral, orbicular ; the whorls sliglitly caniculate above and inwardly, and growing gradually less towards the center.

See MS: $P$.

13-2. Sertularia. Spec. about 60.

operculata, (coral grass, coral wheat-heads,) denticles opposite, pointed and nearly erect, vesicles obovate, covered with a lid; branches alternate.

See MS. P.

8-1. Silpha. Spec. 122.

rugosa, (carrion beetle,) lip dilated, bifid; jaw one-toothed: hlackish; shells ridged with three raised lines; thorax ridged, sinuate be. hind. Sce MS. $P$.

Remarks. This genus is a remarkable fair specimen for affording the student an opportunity to compare the method of dividing an extensive grenus into sections, and that of cutting it up into new genera, according to Cuvier, Lamark, Latreille, \&c.

They stand thus :

Sec. B. Lip rounded, entire; jaw one-toothed. Or genus Mvcetophagus. 14 species. Sec. C. Lip harny, entire; jaw bifid. Or genus Scaphidium. 3 species. 
Sec. D. Lip emarginate, conic; jaw bifld. Or genus IPs. 16 species.

Sec. E. Lip cordate, emarginate, crenate. Or genus Nicrophorus. 5 species.

Sec. F. Lip square, emarginate. Or genus Spharintum. 80 species.

Sec. G. Lip long, entire; antennze serrate. $\mathrm{O}_{\mathrm{r}}$ genus HrPporhLeus. 6 species.

The question seems to be simply this : Is the introduction of these six new names a valuable acquisition to the science, without being accompanied with a new discovery or a new thought of any kind ; excepting that of a new combination of uncooth sounds? Nature decides in favor of some subdivisions of the Linnean genera; but vanity makes a score of new genera where nature and expediency hesitatingly decide in favor of one. Sce MS. $P$.

4-4. Silurus. Spec. 28.

glanis, (bearded-fish,) having six cirri or beards ; dorsal fin single, unarmed; head spatulate, dusky-green. All sizes up to 300 pounds weight.

See MS. $P$.

1-2. Simis. Spec. 64.

Section A. Without a tail. Apes:

satyrus, (orang-outang,) rusty-brown; hair of the fore-arms reversed, haunches covered; body erect generally. From three to five feet high. 
Section B. Tail short. Baboons.

sylvatica, (wood baboon,) face, hands and feet, naked, black, smooth; nails white. Body 3 feet high ; tail 3 inches long.

Sec. C. Tail not prehensile; cheecks pouched; haunches naked. Monkies.

diana, (spotted monkey,) bearded ; forehead projecting; heard pointed.

Sec. D. Tails prehensile; cheeks not pouched; haunches covered. Sapajous, or modest monkies.

capucina, (capucin monkey,) no beard ; skin brown; hair and limbs black; tail shaggy. Very docile. Size of a cat. sciurea, (orange monkey,) no beard, greenish-grey; hind part of the head prominent; nails of the four smaller toes angulate; haunches covered. Very beautiful and graceful in its movements. Always look percons in the face who speak to it.

Sec. E. Tails not prehensile, cheeks not pouched; haunches covered. Sagoins, or playing monkies.

rosalia, (silk monkey,) beardless; head hairy ; outer edge of face and feet red ; nails subulate: body yellowish-white. Body 8 inches long, tail 13.

See MS. P. 
10-2. Sipunculus. Spec. 2.

nudus, (tube-worm, body covered with a close skin, and globular at the lower end. In the ser and under stones. 8 inches long.

saccatus, body covered with a loose skin and rounded at the lower end. Appears as if enclosed in a bag.

See MS. P.

$$
\text { 3-4. Sinex. Spec. } 1 .
$$

Eacertina, (siren,) body eel-form ; branchix ramified. From 8 to 18 inches long. It is said that Capt. La Conte has discovered another species in Louisiana, and that another was discovered in Maj. Long's Expedition. Sce MS. P.

$$
\text { 8-9. Sirex. Spec. } 26 .
$$

gigas, (tailed wasp,) abdomen yellow at the base and tip ; body black-blue. See MS. P.

\section{2-2. Sitta. Spec. 12.}

europoen, (nuthatch, cinereous, beneath redlish ; tail-feathers black, the four lateral ones beneath tipped with white. 6 inches long.

canadiensis, (american nuthatth,) cinereous, pale, rufous beneath; eyclids white. 5 inches long. See Ms. P.

$$
\text { 9-3. S̈оLzi. Spec. } 23 .
$$

vagina, (razor-sheath,) shell linear, straight. roundish, one end margined; linge with a sin. gle opposite tooth in each valye. 6 or 7 inches long.

Sie MS. P. 


\section{1-3. Sorex. Spec. 17}

cristatus, (shrew-mouse,) nostrils carunculate ; tail short. 4 inches long.

aquaticus, (water shrew, hind feet palmate ; fore

feet white ; tail short, white. Size of a mole. bicolor, (swaimp shrew,) tail middle length, nakedish; body blackish, cinereous beneath; toes fingered. 4 inches long.

See MS. P.

4-6. Spatularia. Spec. 1 or none.

[A bad genus, taken from Squalus.] $S \in$ MS. P.

$$
\text { 4-3. Spirus. Spec. } 39 .
$$

auratus, (gilt-head, ) a semi-lunar golden spot between the eyes. Sometimes weighs 10 pounds. See MS. I'.

4-1. Sphagebranchus. Spec. 1.

rostratus, (pike-nose,) the nose extended so as to have the appearance of a beak.

Sce MIS. P.

$$
\text { 8-9. Sгнкх. Spec. } 129 .
$$

maculata, (solitary-wasp,) thorax spotted ; first segment of the abdomen with a white dot each side, second edged with white.

See MS. P.

8-10. Sphinx. Spec. 175.

Remarks. This genus resembles the genas Phalæna, and approaches the Papilio. All the species of Papilio fly in the day time only; those of the Phalæua in the night; and of this genus, *22 
early in the morning or near erening. The larra have sixteen feet, and are pretty active.

ocellata, (hawk-moth,). wings angular, lower ones rufous with a blue eye-spot. Chrysalis dark chesnut-brown.

See MS. $P$.

\section{9-3. Spondyutus. Spec. 4.}

gaderopus, (thorney oyster,) shell slightly cared and spinous; one valve extends hack beyond the other ; colour variable. See MS. $P$.

13-2. Spongia. Spec. 49.

officinalis, (common sponge,) irregular or subghobular, porous, tough, lobed, woolly. Linneus supposed that the large serpentine cavities in this species were made by marine animals gnawing their passages into it ; though their regularity and the prominences at their superficial terminations seem to indicate that they are an essential part of the organic structure of the animal.

prolifera, (branched sponge,) hase flat, spread; branches numerous, suhpalmate, ending in finger-like divisions. Grows in large bunches upon oyster shells, \&c.; sometimes six inches high.

fluviatilis, (river sponge, green, erect, fragile, consisting of numerons irregular branches. Very abundant in the upper lake on Catskill mountain, near the Mountain House. Has a fishlike smell.

See MS. $P$. 
14-6. Sequalus. Spec. 34.

zygoena, (hammer shark, head broad, resembling: a hammer. 6 feet long. Rapacious.

vulpes, (fox shark,) upper lobe of the tail as long as the body. 7 feet long. Exceedingly voracious.

slaucus, (blue sliark, sides of the tail smooth : lower part of the back with a triangular dent. 3 to 14 feet long.

carcharias, (white shark, teeth triangular, serrate. Grows to 30 feet long. Must clreadful of all sea animals.

SeC MS. $P$.

6-2 to 5. Śquilla. Spec. 6.

mantis, (false craw-fish,) hands with a single fang; compressed, falcate, serrate ; body subangular : tail serrate with spines. Eatable.

See M.S. P.

8-5. 'Staphylinus. Spec. 156.

murimus, (rove beetle, pubescent, cinereous, clouded with black; abdomen deep black; leg' black; shells blue.

See MS. $P$.

2-6. Sterna. Spec. 25.

hirundo, (swallow tern, two outer tail-feathers half black, ha!f white. Sometimes outer tailfeathers white. A foot long.

See MS. $P$.

4-1. Sternoptrix. Spec. 1. diaphana, (amber fish,) compressed, truncate be- 
fore, narrowed and silvery behiud ; eyes large, amber-colour.

See MS. $P$.

2-1. Strix. Spec. 50.

Sec. A. Eared owels.

bubo, (giant owl,) body tawny. A variety has brownish wings with dark body Another has naked legs. Another is blackish-yellow, variegated with white.

virginiana, (brown owl, ) body brown above, varied with tine zigzagr tawny and cinereous lines, pale ash beneath with transverse brown streaks; throat and sides of the breast orange, streaked with brown.

asio, (red owl, body ferruginous above, cinereous. beneath; wings with five white dots. 10 inches long.

americana, (american owl,) head and body cinereous above, rusty beneath; rump white spotted with hlack; wings and tail rusty with cinereous and grey transverse lines.

otus, (long-eared owl, ) feathers of the ears six.

A variety is much darker, another smaller. It is about 14 inches long:

brachyatos, (short-eared owl,) horns short; body brown above, feathers edged with yellow; beneath pale yellow, with longitudinal dusky streaks. 14 inches long.

noevia, (mottled owl,) body grey, paler beneath, spotted with black and rusty; feathers of the head and breast dotted with black. 11 inches

long.

sife MS. P. 


\section{Sec. B. Earless owls.}

nyctea, (snow-owl,) body whitish, with a few brown lunate spots. Often snow-white in the winter. 2 feet long.

nebulosa, (clond owl, head, neck, breast, back and wing-coverts brown, spotted with white; belly dirty white, streaked with brown; tail with brown and whitish bands, and whitish at the tip. 2 feet long.

flammea, (common owl,) body pale yellow above with white dots, whitish beneath with blackish dots. 14 inclies long.

ulula, (speckled owl,) body brown above, spotted with white; tail-feathers with linear white

bands. 14 inches long, but often much smaller. funerea, (canada owl,) body bruwn above with a few large white spots, white beneath with trans. verse narrow brown bars ; tail long with broad brown and narrow iwhite bars.

acadica, (acadian owl,) body bright bay, spotted with white above, dirty white mixed with rusty

beneath. 7 inches long.

passerina, (sparrow owl, yuilt feathers with five rows of white spots. About 8 inches long. A smaller variety has the eyes surrounded with white circles; and a larger variety has a white chin and variegated wings.

albifrons, (white-faced owl,) body rusty-brown, paler beneath ; forehead white; quilt-feathers barred with black and white. 5 inches long. See MS. $P$.

4-1. S'tromateus. Spec. 3.

paru, (stromat,) back golden, helly silvery ; body 
slender, covered with small deciduous scales. See MiS. P.

9-4. Strombus. Spec. 53.

gigas, (dinner-horn,) lip rounded and very large; shell crowned ; belly and spire with conic expanded spines. 10 inches long, 9 broad. See MS, $P$.

\section{1-1. Strongylues. Spec. 1.}

equinus, (horse glass-worm,) head opake ; intestine black. Inhabits the stomachs of horses. Sce MS. P

\section{2-5. Struthio. Spec. 4.}

camelus, (black ostrich,) feet two-toed; feathers of the body lax. black, decomposite, webs equal each side; quill and tail-feathers snowy, waved, long, here and there black on the edge or tip. Lays 40 or 50 eggs, each as large as a child's head. 7 to 9 feet long.

casuarius, (cassowary ostrich,) feet three-toed : helmet and dewlaps naked; feathers brownishblack, lax. 5 feet long.

See MS. $P$.

2-2. Strurnus. Spec. 17.

vulgaris, (starling, stare,) bill yellowish ; body black, with white dots. A variety is white; another cinereous with black legs and bill. One white variety las a black crown, neck, wings and tail; snother has two black spots above the eyes near the bill. 9 inches long. Sse MS. P? 


\section{4-1. Struephorus. Spec. 1.}

chordatus, (thread-tail fish,) body gradually diminishing as it approaches the tail, which terminates in a process or string of enormous length.

10 inches long; tail process 22 inches.

See MS. P.

8-11. Struors. Spec. 2.

gallica, living on wasps.

See MS. 1.

\section{1-6. Sus. Spec. 5.}

scrofu, (commion hog,) tail hairy ; ears oblong, acute; back bristly. In the will state the bristles are very long on the forepart of the back, and the ears are roundish.

porcus, (guinea-hog,) back prickly on the hindparts; tail reaching to the ground ; naval cistiferous. Some have erect ears a little pointed, and a tail reaching nearly to the ground; body reddish. S naller than the scrofiu. tajassu, (mexican hog;) tail none; back with a glandular orifice. 3 feet long. Runs wild in woods and does not wallow in mud.

africanus, (cape hog,) two fore teeth in the upper jaw ; body covered with long fine bristles; tail slender, tufted.

ethiopicus, (ethiopian hog,) no fore teeth; a soft wrinkled pouch under the eyes; body thick, broad, nakedish, with bunches of blackish-brown bristles; skin lax, black under the eyes, from which hangs down a large broad, flat, tube; tail naked. Of hideous appearance, fierce and swift. Four feet and a half long ; burrows under ground. 
babyrussus, two crooked tusks piercing through the upper part of the face ; body slender, greybrown; hair almost woully ; tail long, twisted, tufted at the tip.

See MS. '?.

\section{4-5. Sygnatuus. Spec. 5.}

typhle, (pipe-fish, ) caudal, anal, and pectoral fins,

radiate; body six-silled. A foot long.

acus, (needle-fish,) caudal, anal and pectoral fins

radiate ; body seven-sided. 2 to 3 feet long.

See MS. P.

\section{4-1. Synbizanchus. Spec. 2.}

marmoratus, (surinam eel,) head thick, snout rounded; teeth obtuse.

See MS. $P$.

\section{$\mathrm{T}$. \\ 8-12. Tabanus. Spec. 52.}

bovinus, (ox-fly,) eyes greenish ; back of the abdomen with white triangular longitudinal spots. Sce MS. P.

11-2. T正XIA. Spec. 100.

Sec. A. Heud armed with hooks; found in other parts besides intestines; furnished with a vesicle behind. Hydatids.

visceralis, (swelling hydatid,) per-form, enclosed in a vesicle; broad on the forepart and pointed behind. In tumid riscera.

Sec. B. Head armed with hooks; found only in the intestines; not furnished with a terminal vesicle. Tape-wornis.

solium, (great tape-worm,) articulations long and 
narrow with narginal mouths, one on each joint, and generally alternate ; ovaries arborescent. Inhabits human intestines. Sometimes 60 feet loug:

vulgaris, (common tape-worn,) articulations short and broader, with a mouth in the centre of each joint; ovaries stellate round the month. Inhabits human intestines, three or four together; sometimes 15 feet long. If cut or broken into parts, each part will live.

See MS. $P$.

$$
\text { 1-3. Talpa. Spec. } 4 .
$$

auropoca, (mole,) tail short; feet five-toed. White; yellow, cinereous, variegated, brown, \&c. : head lengthened into a long snout; fore feet broad ; eyes small.

See MS. $P$.

$$
\text { 2-5. Tanagira. Spec. } 48 .
$$

estiva, (tanager,) red; bill yellowish. 6 inches long.

rubra, (red tanager,) red; wings and tail black; tail-feathers tipped with white. Sometimes the tail is not tipped with white. 6 inches long. See MS. $\boldsymbol{P}$.

$$
\text { 2-5. Tantalus. Spec. } 23 .
$$

igneus, (ibis,) heal and neck black; legs green; body varied with glos.y-blue, blackish, green and claret; dark rufous beneath ; quill and tailfeathers green-gold. 3 inches long. Sec MS. P.

$$
\text { 1-6. Tapir. Spec. } 1 .
$$

americanus, (tapir, snout long, extensile, flexible: hisses. 


\section{9-3. Tellina. Spec. 100.}

Section A. Ovate and thickish.

fragilis, (brittle tellina,) shell ovate, white; gibbous with transverse recurved stria; beaks yellowish. An inch broad.

Section B. Ovate, compressed.

radiata, (radiated tellina,) shell oblong, with faint longitudinal strix, polished ; suture behind the beaks caniculate; whitish with red rays. Sometimes with unequal sides, large, white, brown, yellow, \&c.

Section C. Suborbicular. Genus Crclas of Bruguieres.

similis, shell suborbicular, convex, base a little flattened; having nearly equi-distant raised concentric lines, giving a furrowed appearance to the surface ; epidermis brownish ; hinge with minute oblique teeth, lateral ones distinct, elongated. Length the third of an inch, breadth a little less. Americau fresh water shells. dubia, shell oblique, subovate, convex, wrinkled concentrically, whitish with a darker band; beaks nearer one end, whitish within ; primary teeth distinct, two divaricating ones in one valve, and in the other one. Length one-fourth of an inch, and breadth a little less. American fresh water shells.

See MS. P.

8-5. Texemio. Spec. 90.

molitor, (meal worm,) oblong, piceous ; shells 
striate. Often found in meal and breall from large bakeries.

See .MS. $P$.

8-9. Tenturedo. Spec. 152.

lutea, (yellow saw-fly,) antenna yellow; abdomen yellow, the second segment black.

See MS. $P$.

\section{9-1. Tетнуs. Spec.2.}

fimbria, membrane or lip crenulate or pointed ; body white ; lip rounded, spread over the forepart of the hearl and broader than the body.

Sec MS. $P$.

\section{4-5. Tetrodon. Spec. 12.}

levigatus, (globe fish,) belly dilatible and prickly before the anal fin. 1 or 2 feet long. See MS. $P$.

$$
\text { 9-4. Teredo. Spec. } 3 .
$$

navalis, (ship-worm,) shell thin, cylindrical, smooth.

See MS. $P$.

\section{8-8. Trrmes. Spec. 10}

fatale, (white ant, wood-cater, ) body brown above; thorax with three segments ; wings pale, with a testaceous rib. This species live in communities, and build mole-hills twelve feet high. A family of them will gnaw a beam, 12 feet long and 2 feet in diameter, to a mere shell not thicker than paper in one day. pulsatorium, (false death-watch,) nearly or quite apterous; abdomen oblong; mouth red; eyes yellow. The female beats like the ticking of a 
watch, which is her call for the male. Inhab. its old wainscoting and wooden furniture.

See MS. $P$.

3-1. Testudo. Spec. 35.

Section A. Legs fin-form, the foremost longest. Sea-turtles.

coriacea, (leather-shell tortoise, shell coriaceous,

longitudinally groover. Sometimes tuberculate. Sometimes 6 feet long and three broad. Not eatable.

mydas, (green turtle, ) fure part two-clawed; hind feet solitary ; shell oval. Beak broad or narrow. Flesh eatable, green.

imbricata, (shell tortoise, fore and hind feet two. clawed ; shell plates lax, lying over each other. These small plates are the tortoise-shells of the shops.

Section B. Feet palmate; shell joined to the chest by a membrane, and propped each side in the middle, by two processes of the chest.

clausa, (woods turtle,) scutels of the disk keeled; under shell closing, so that the whole body is shut in a water-tight box.

pensylvanica, fore feet five-clawed, hind ones four : tail tipped with a sharp horn.

Section C. Feet clavate, clawed; shell convex; joined to the chest by bony commissures.

denticulata, (heart tortoise, ) feet subdigitate ; shcll round-cordate, with the margin irregularly scooped. meleagris, (speckled tortoise ${ }_{2}$ ) feet digitate; shelk 
oval, smootl, sjeckled with aumerous yellow dots. 5 or 6 inches long.

$$
\text { 2-1. Tetiao. Spec. } 73 .
$$

Section A. Spots over the eyes natied; legss doreny. Grous.

urogalius, (grous, ) tail rounded ; armpit white. 2 feet 9 inciues lons.

cupido, (small grous,) back of the neck with winglike appendages. Less than a partridge. umbellus, (american grous, variegated with brown, rufous and black, A foot and a half long.

Sec. B. Orbits granulated ; legs naked and spurred. Partridges.

perdix, (common partridge,) a naked scarlet spot under the eye ; tail ferruginous ; breast brown : legs white. Coloar various. 13 inches long:

Śec. C. Orbits granulated; leggs naked and not spurred. Quails.

virginiomıs, (american quail,) a black band above and below the eyes; crown with a tawny line. marylandus, (white-eyed quail,) eyebrows white: neck dotted with black and white. see MS. P.

$$
\text { 8-7. Thrips. Spec. } 8 .
$$

physapus, (wheat fiy,) upper wings glaucous : body black. Iarva yellow, six-footed. See MS. P.

\section{8-12. Tipula. Spec. 134.}

pecticornis, (father long-legs,) antenna pectinate: wings with a black spot; abdomen rufous at tho 
base, barred with yellow in the middle and tipped with black.

clavipes, (crane.fly, brown ; tarsi annulate with white, ovate and thickened in the middle.

See MS. P.

2-2. Tonus. Spec. 16.

obscurus, (tody, olive-brown, yellowish-white beneath; chin pale; quill and tail-feathers edged with grey.

See MS. P.

4--3. Trachichturs. Spec. 1.

anstralis, scales fringed and covered with small spines; tail strongly forked. 5 inches long. See MS. P.

4-2. Trachinus. Spec. 1.

draco, (weever, sting-fish,) under jaw longer, back straight, brown. One foot long:

See MS. P.

1-3. Trichechus. Spec. 4.

kosmarus, (morse, tusks in the upper jaw remote, projecting. Weighs about 30 pounds. durong, (walrus,) lusks in the upper jaw projecting, approximate.

See M. P.

\section{4-1. Trichures. Spec. 2.}

Lepturus, lower jaw longer than the upper. Three feet long. Body naked, silvery.

See MS. P.

11-1. Trichocephalus. Spec. 6.

hlominis, (hair-head worms,) body slightly crenate above, smooth beneath; very finely striate on 
the fore part. Inhabits intestines of sickly children. 2 inches long.

See MS. $P$.

\section{4-2. Trichoda. Spec. 60.}

sol, (hair-head sun,) globular, and every where radiate with hairs.

See .MS. $P$.

4-3. Trichopus. Spec. 1.

trichopterus, iris golden; pectoral fins thin, anal and caudal spotted with white. 4 inches long. SeQ MS. P.

$$
\text { 4-3. Trigla. Spec. } 14 .
$$

lyra, (gurnard, piper,) appendages three; nostrils tubular; tail lunate. Two feet long.

See MS. $P$.

$$
\text { 2-5. Tringa. Spec. } 48 .
$$

vanellus, (lapwing,) legs red, crest pendent; breast

black. Colours greatly variegated; flesh and egges delicious.

interpres, (turnstone, sea dottrel,) legs red; body

black varied with white and ferruginous ; breast and belly white.

novcébracensis, (sandpiper, ) dusky, white beneath; breast spotted with brown ; tail cinereous ; tail with black and white lines.

lobata, (phalarope,) bill subulate, bent in at the tip ; feet piunate; breast waved with white; feet lobate.

cinclus, (sanderling, purre, stint,) bill and lege black; lores white; bolly and rump grey and brown. Seven and a half inches long. See MS. P. 


\section{9-1. Triton. Spec. 1.}

littoreus, (water salamander,) body oval ; heat oblong; proboscis long. In sea.

See MS. $P$.

4-1. Triurus. Spec. 1.

trifurcus, (tripple-tail, ) the last fin above and below extending beyond the tail, gives the appearance of three tails.

See MS. P.

2-2. Trochlus. Spec. 65.

colubris, (american hum.bird,) green gold ; tailfeathers black, the thres lateral ones ferruginous tipped with white; chin flame-colour. 3 and a half inches long. The female is brown. above and whitish beneath.

See MS. P.

9-4. Trochus. Spec. 133.

magus, (top-shell,) shell obliquely umbilicate and convex; the ridges of the whorls rising into obtuse tubercles. Shell with zigzag red stripes.

See.MS. $P$.

$$
\text { 2-3. Trogon. Spec. } 9 .
$$

curucui, (curuke, green gold, tawny beneath; chin. black. 10 inches long. Colours variable. See .MS. $P$.

13-2. Tubipora. Spec. 10. serpens, (pipe coral,) with erect cylindrical very short distant axillary tubes, and a creeping. dichotomous divaricate base. Minute, white or pale red. Adheres to fuci, \&c.

see MS. $P$. 


\section{3-2. Tubularia. Spec. 26.}

fistulosa, (coral whistle,) stems dichotomous, with small cylindrical joints, and lozenge-form cells.

5 inches long.

See MS $P$.

9-4. Turbo. Spec. 151.

corticaria, (wreath snail,) shell dextral, cylindric, obtuse at the apex ; whorls fine smooth ; aperture suborbicular; a tooth on the pillar near the outer angle ; inner angle with an angular projection. The tenth of an inch long. Under bark. The Odostoma of some. An American shell.

See $M S: P$.

\section{2-2. Tundus. Spec. 136.}

minor, (little thrush,) tawny, white beneath ; breast yellowish, with black spots. 7 inches long. migratorius, (redbreast thrush,) grey ; belly rufous; eyelids white; outermost tail feathers white on the inner tip. 9 inches long.

polyglattus, (mocking thrush,) dusky-ash, beneath pale ash ; primary quill-feathers white on the outer balf.

novoboracensis, (thrush,) waved with black and pale ferruginous, blackish beneath ; wings and tail glossy-green, a black stripe above and below the eyes. Size of a black-bird. fiscus, (brown thrush,) olive-brown; breast and belly whitish, spotted with brown; primary quill-feathers and legs black. See MS. P. 
U.

2-2. Upupa. Spec. 10.

epeps, (hoopœ, ) variegated with blackish and rufous-white, reddish-white, beneath ; crest paleorange tipped with black; tail black with a white bar. A foot long.

See MS. P.

4-2. Uranoscorus. Spec. 2.

scabex, (star-gazer, back smooth ; head sprinkled over with minute warts. A foot long. S.e M.S. P.

\section{1-3. Ursus. Spec. 10.}

arctos, (common bear, ) blackish-brown ; tail short ; thumb narrower than the after toes. Colour varies, even to white.

maritimus, (white bear, polar bear,) white ; tail short; head and neck lengthened; fur long and soft.

americamus, (american bear,) black ; throat and cheeks rusty-brown ; ears longer; snout sharper.

meles, (badger, ) body cinereous above, black beneath; a longitudinal black stripe including the eyes and ears; tail the colour of the body, 2 feet long.

lotor, (raccoon,) tail annulate; a black transverse stripe by the eyes. Sleeps by day and goes out at night. Destroys indian corn rapidly in the field.

luscus, (wolverene,) tail long; body rusty-brown; snout blackish. gulo, (glution,) tawny-brown, tail same colour; middle of the back black.

See MS. P. 


\section{V.}

2-5. Vaginalis. Spec. 1.

alba, (white sheath-bill,) bill black at the base; sheath a yellow or black horny plate nearly covering the nostrils; feathers white. 15 inches long.

See MS. P.

$$
\text { 4-3. Vandellius. Spec. } 1 .
$$

corpensis, (sword-body,) slender, compressed laterally.

Sce MS P.

9-3. Venus. Spec. 154.

mercenaria, (common clam, round clam,) shell thick, strong, with slight transverse strix and covered with a brown cuticle, (which sometimes becomes pavonine, ) pale violet or white within; depression on the outside behind the beaks ovate or subcordate ; margin crenulate. Shell four inches by three, and about two inches thick. A very cheap and good article of food among the indigent class in New-York and other seaports in the northern states. Twenty-five cents for clams, and five cents for potatoes, will furnish a comfortable meal for fiftcen persons, with no seasoning excepting a little common salt.

Sce MS. P.

$$
\text { - 8-9. Vespa. Spec. } 213 .
$$

crabro, (hornet,) thorax black the fore part rufous without spots ; incisures of the abdomen with a double contiguous black dot. Nests are attached to house and barn timbers, \&c. 
vulgaris, (common wasp,) thorax black with an interrupted yellow line each side; scutel with four yellow spots ; abilomen yellow, the incisures with distinct black dots. Live in large societies, and construct a pendent cone with wuody fibres in an incipient siate of decay. The fibres are manufactured into thin concentric membranes, laid over each other at a distance sufficient to leave a passage between them. The combs are placed in the base of the cone.

Remarks. Five of the genera abdopted by Latreille are the sections of this genus. Thus : Sec. B. Lip vate, as long as the jaw, is the Mellinus. 8 species.

Sec. C. Lip compressed, rounded, longer than the jaz, is the Phllantuus. 14 species. Sec. 1). Lip short, horny, is the Crabro. 56 species.

Sec. E. Tongue bifid, retractile, is the Masaris.

2 species.

Sec. F. Tongue inflected, five-cleft, is the BEMBEx. 17 species

Each of these might be subdivided again and again ; and so might every genus in every department of natural history, if it contains more than one species.

See MS. P.

\section{1-3. Vespertilio. Spec. 25.}

murinus, (commou bat,) tailed; nose and mouth simple; ears less than the head; mouse-colour tinged with red. Two and a half inches long. Flies at night only. Upper fore teeth four in number, lower six. 
Vespertilo, Viverra.

novoboracensis, (american bat,) tail long; nose short, acute; ears short, round ; bright tawny above, paler beneath; a white spot at the base. of each wing. Length same as the last.

Remark. Both of these species are torpid during the winter and hang up by their hind claws in caverns, \&c. They are found in the five caverns of the Helderbergh in Albany county every day in summer as well as winter, hanging in bunches like bees before swarming. They fly out during the night in the summer season.

See MS. $P$.

14-2. Vibiro. Śpec. 20.

nser, (goose animalcula,) oval with a long neck, and a tubercle on the back. In stagnant water where Lemna grows.

see MS. P.

$$
\text { 1-3. Viveria. Spec. } 52 .
$$

Remarks. Shaw, whom I have followed, consiller's the distinction between the Viverra and Mustela as not founded in nature. He has therefore included all the species of Mustela under the Viverra; excepting those of the Mustela, whose hind feet are palmate. These, including the otters, minks, \&c. constitute the genus LuTiR.

vulpecula, (southern weesel,) entirely chesnut; snout elongated. Odour filthy.

putorius, (striped weesel,) blackish, with five dorsal parallel whitish lines. Sleeps by day and prouls by night. Tail white at the tip. Odous: intolerable when irritated.

memphitis, (skunk,) back white, with a longitudinal black line from the middle to the tail. 16 
inches long. Defends itself by the most pungent and intolerable odour.

civetta, (ciret,) tail spotter above, brown towards the tip ; mane chesnut ; back spotted with cinereous and brown. Size of a cat. Produces the civit odour.

genetta, (genet,) tail annulate; body spotted,

blackish-tawny. 7 inches long.

martes, (martin,) body blackish-tawny; throat and breast yellow.

zibellina, (sable,) borly dark-tawny ; forehead

white; throat cinereous. Sometimes snow-

white; sometimes it has a collar of white or yellow spots.

foeticlus, (polecat,) body blackish-yellow ; mouth and ears white. Sleeps by day and wanders

by night. Emits a feticl oduur.

furo, (ferret,) cyes red, fiery ; body long, slender : pale yellow.

vu'garis, (white-bellied weesel,) body white, or tawny-brown above, white beneath; tail the colour of the body. Prowls by night. Fetid and dirty.

Sce US. P.

$$
\text { 9-4. Voluta. Spec. } 144 .
$$

pallida, (mitre, volute,) shell entire, oblong-ovate, with an elevated spire; pillar with four plaits. See MIS. $P$.

$$
\text { 14-1. Vowrox. Spec. } 9 .
$$

globator, (globe jelly, spherical, membranaceous, with varions sized homogeneous molecules. In staguant water and regetable infusions.

See MIS. $P$.

$$
\text { 14-1. Vorticrlat. \$pec. } 5 \% \text {. }
$$


and repy much branched, long pedicels. In stagnant waters.

See MS. P.

2-1. Vultur. Spec. $1 \%$

gryphus, (condor,) of vast size; a caruncle on the crown as long as the head; throat naked. Wings spread 16 feet in some cases.

aura, (carrion vulture,) body grey-brown; quillfeathers black; bill white. Fetid and lazy. See MS. P.

\section{X.}

8-11. Xenas. Spec. 2.

peckii, oval-oblon, without claws or rings, with the anterior end dilated in the form of a head. See MS, P.

$$
\text { 4-1. Xiphias, Spec. } 2 .
$$

gladius, (sword-fish,) dorsal fin falcate; back black, belly white; upper jaw four times as long as the under and pointed. 20 feet long.

See MS. P.

$$
\begin{aligned}
& \text { Y. } \\
& \text { 2-3. YUNX. Spec. } 1 .
\end{aligned}
$$

iorginilla, (wry-neck,) green, varied with brown and blackish spots; tail-feathers wared with black spots, streaks and bars.

See MS. P.

$$
\text { Z. }
$$

4-3. Zeus. Spec. 10.

sallus, (doris,) tenth ray of the dorsal, and second ray of the anal fin longer than the body. See MS. P. 


\section{$(280)$}

\section{SUMMARY.}

Four hundred and sixty-one genera are described in this text-book. These embrace every known species of the Animal kinglom. Lecepede, Cuvier and others of the Freuch School, have subdivided most of these genera, until their list is extended to thousands, including their subgenera. In numerous cases they have merely given Greek and Latin names to the Linnean sections of species. The student should be told at the outset of his course, that all the animals are embraced under these 461 genera, which are included in the Frencl genera.

The genera described in this text-book are â" ranged according to the classes of Cuvier, as follows : Under Class 1, are 54 genera-Class 2, 91 -Class 3, 16-Class 4, 92-Class 5, 10-Class 6, 4-Class 7, 4-Class 8, 88-Class 9, 48Class 10, 5-Class 11, 14-Class 12, 4-Class 13, 16-Class 14, 15. Total 461.

At the commencement of the present century, about 21,300 species had been described. I have set down the number of species described at that time under each genus, as nearly as it could be ascertained. Though the number has been encreased several thousands since that time; the student may form an estimate of the relative extent of each genus, by that number. The genera at that time stood thus, under the Linnean classes. Class 1, 49 genera-Class 2, 90-Class 3, 12Class 4, 72-Class 5, 123-Class 6, 118. Total 461. 


\section{$(281)$}

\section{DIRECTIONS FOR STUDEN'TS.}

This text-book embraces not only a system of to be used for ascertaining the names of animals; but also the most important elementary principles of the science of Zoulogy, given in a concise familiar manner.

The student should commence at page 7 and study the whole attentively to the middle of page 41. Then read the remarks on pages $53,62,76$, $79,91,94,96,98,111,118,120,123,125$ and 129. Also the directions on pages 133,134 and 135. Also the sections and remarks upon the species, under the generic names Silpha, p. 253, and Vespa, p. 275.

Several species of American fresh-water shells are described for the purpose of exercising students in the study of shells; chiefly from Say and Barnes, most of which they propose as new. More might have been copied from Say, in Long's Expedition. But I hink that most of these new species require reviewing. On comparing the characters with descriptions of European species, I should be in clined to recommend an exchange of specimens with European naturalists, before they are offered as new, and in some cases a comparison of the proposed new species with each other, especially some of the new species of Mya, of the section * 24 
Unio. They may all be tenable; and I would not in any case, set up my doubts against the convictions of these industrious naturalists. But $\mathbf{I}$ prefer delaying any farther adoption of their new species, until they have extended their collections and made farther comparisons. I have the same objections to the adoption of other proposed new species of animals from other naturalists, which I might have introduced for students' exercises. I consider this part of Natural History as very unsettled in America ; and that it is, as it were, just emerging from a chaotic state-it is so, at any rate, in my oven mind. 


\section{INDIX}

OF ENGLISH NAMLS AND OF ELEMENTARY TERMS.

N. B. The elementary terms are printed in ilalics.

\begin{tabular}{|c|c|c|c|c|c|}
\hline A. & 31 & & & & \\
\hline al fins, & $\begin{array}{l}31 \\
31\end{array}$ & $\begin{array}{l}\text { Barnacle, } \\
\text { Basse, }\end{array}$ & $\begin{array}{r}113,204 \\
241,248\end{array}$ & Byssus, & \\
\hline al ring & 31 & Bat, & 275 & C. & \\
\hline ell, & & & 55,274 & Cachelot, & 60,240 \\
\hline nta, & 222 & & 30 & fly, & 107 \\
\hline & 74,179 & ed fish, & 254 & & 252 \\
\hline & 202 & & 57,166 & & 60,161 \\
\hline h, & 82,259 & & 170 & sow, & 69 \\
\hline$o g y$ & 27 & & 108,142 & & 88,177 \\
\hline & 31 & er, & 215 & C & 225 \\
\hline$s$ parts & 28 & & $67,21 \mathrm{i}$ & & 34 \\
\hline & 123 & & 66,160 & orm, & 91,247 \\
\hline & 89,207 & 2,150 & $20^{\prime}$ & & \\
\hline rm, & 92,207 & sta, 182[ & {$[253,2 \approx 9]$} & & 56,18 \\
\hline & 224 & & 158 & & \\
\hline 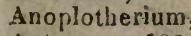 & 59 & & 71 & & \\
\hline 108 & $, 187,267$ & rd, & 64,228 & & 105 \\
\hline er, 58 & 23 & & 234 & fins, & 3 \\
\hline & & & 83 & & 16 \\
\hline & & ker, & 93,197 & pede, 98 & $3,201,25$ \\
\hline & 54 & & $, 105,162$ & C & 2 \\
\hline & 92 & & 225 & & $7 \%, 20$ \\
\hline $\mathrm{um}_{\text {, }}$ & 141 & & 86 & n birc & $1:$ \\
\hline & 29 & & 138 & 0 & \\
\hline & & & 75 & & 63,1 \\
\hline rl & 53 & Bo & $17 \varepsilon$ & le claros & \\
\hline & & & 54 & & 178 \\
\hline & 32 & & 226 & 0 & \\
\hline $\mathbf{s}$ & 77 & & 88 & & 56,2 \\
\hline & 31 & & 30 & 114 & $4,115,2^{n}$ \\
\hline & 29,30 & & 159 & $\mathrm{Cl}$ & 8,37 \\
\hline & 165 & But & & fication, & \\
\hline & & & 105 & & \\
\hline & & & & & \\
\hline & & & & $\mathrm{Co}$ & \\
\hline & & & & & \\
\hline & & & & & \\
\hline & & & 71,229 & roach, & \\
\hline & & $x^{2}$ & & & \\
\hline & & & 230 & & 17 \\
\hline & & Aiv & & & \\
\hline & & & & & \\
\hline
\end{tabular}




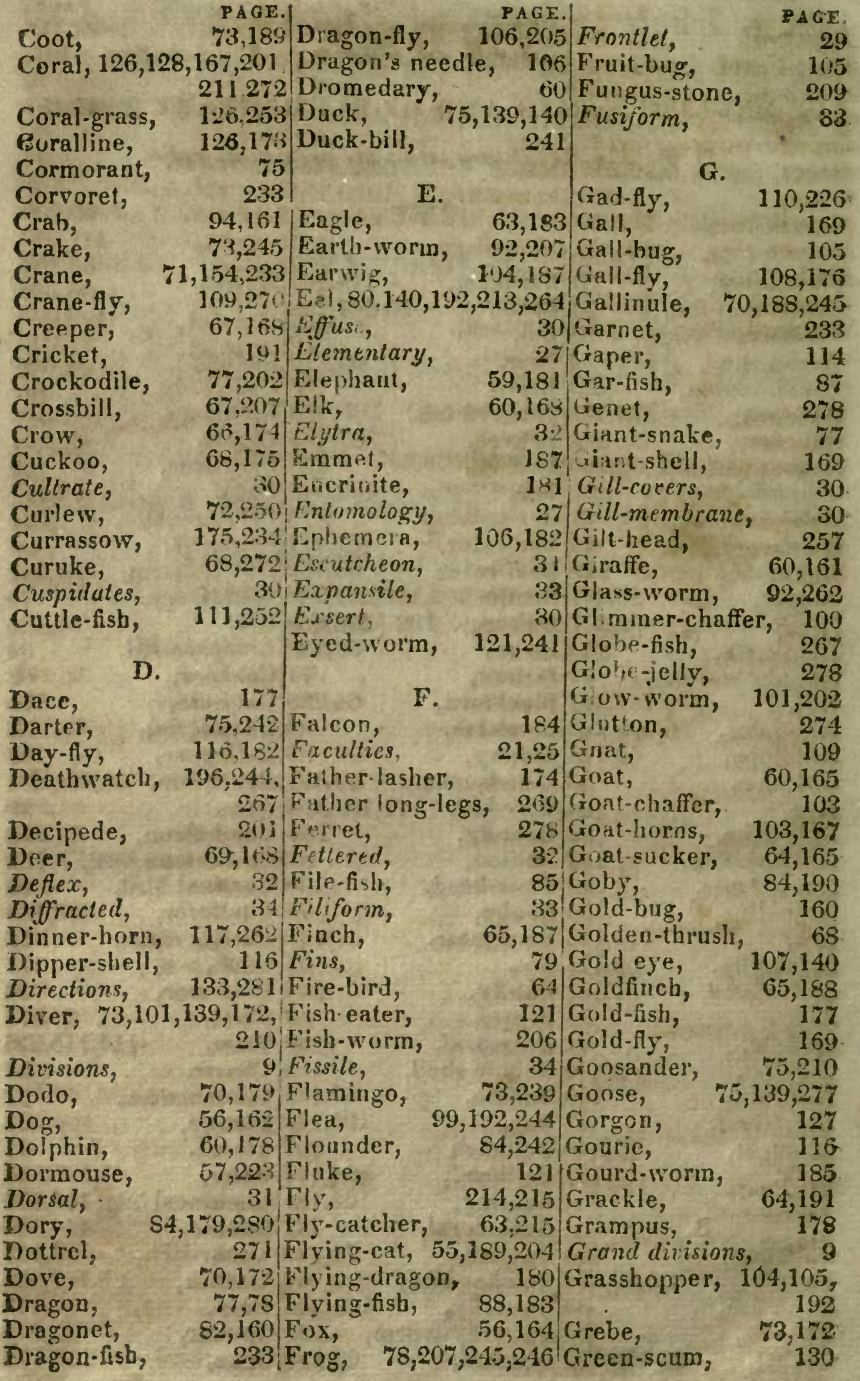




\begin{tabular}{|c|c|c|c|c|c|}
\hline & $\begin{array}{r}P A G E \\
2\end{array}$ & & $\begin{array}{r}\Delta G \mathrm{R} \\
31\end{array}$ & & $\begin{array}{l}\text { PAGE, } \\
\text { S1,138 }\end{array}$ \\
\hline $\begin{array}{l}\text { rey-beard, } \\
\text { rosbeak, }\end{array}$ & $\begin{array}{l}97,238 \\
65,207\end{array}$ & Hydatid, & 264 & Leather-chaffer, & $\begin{array}{l}r, \quad 101, \\
\quad 178\end{array}$ \\
\hline roundling, & 171 & I. & & Leech, & 93,197 \\
\hline & & Ihex, & 61 & & \\
\hline & 70,269 & Ibis, & 72,265 & Le & \\
\hline a-ben, & $\begin{array}{r}234 \\
70,225\end{array}$ & neumon, & $\begin{array}{r}1799 \\
201\end{array}$ & $\begin{array}{l}\text { Leop } \\
\text { Lepis }\end{array}$ & $\begin{array}{r}186 \\
99,204\end{array}$ \\
\hline pig, & 58,166 & Ichthyology, & 27 & & 117,232 \\
\hline & 74,203 & Idiot & & & 5,188 \\
\hline wi & $\begin{array}{r}86,271 \\
248\end{array}$ & et, & & ant, & $\begin{array}{r}50,180 \\
106,223\end{array}$ \\
\hline H. & & & & & $\begin{array}{l}77,202 \\
94,161\end{array}$ \\
\hline & 189 & & & & \\
\hline & 90,190 & & & & j,170,192 \\
\hline & 130,270 & $I_{1}$ & 34 & & \\
\hline air-snake, & 93,191 & & & Louse, 99,1 & 22 \\
\hline & & & & & \\
\hline & & & & & \\
\hline arc & 205 & & 72,232 & & \\
\hline & & & 182 & $M$ & \\
\hline & & & $\begin{array}{l}164 \\
17+4\end{array}$ & & 86,251 \\
\hline & 18 & kes & & & 66,174 \\
\hline & & & & & 34 \\
\hline & $, 138,235$ & & (1,191,166, & & 64,241 \\
\hline & & $\mathrm{Je}$ & 179 & & \\
\hline & & & & & $z 7,1$ \\
\hline & & $\mathrm{K}=$ & & & \\
\hline tamus, & & & & & 64,278 \\
\hline & 84 & & & & $\begin{array}{r}197 \\
59\end{array}$ \\
\hline & & & 32 & & \\
\hline & $y 150$ & & & & 166 \\
\hline & $\begin{array}{r}67,159 \\
108,275\end{array}$ & & 6 & $\begin{array}{l}M \\
M\end{array}$ & 8 \\
\hline & & & & & \\
\hline & & & 35 & & 10 \\
\hline & & ird, & & $A$ & \\
\hline & 11 & & 104,171 & & \\
\hline & & & & & 116,278 \\
\hline & 12 & & & & \\
\hline & & & & & 55,265 \\
\hline & & & & & \\
\hline & & & & & 54 \\
\hline & & & & & \\
\hline
\end{tabular}




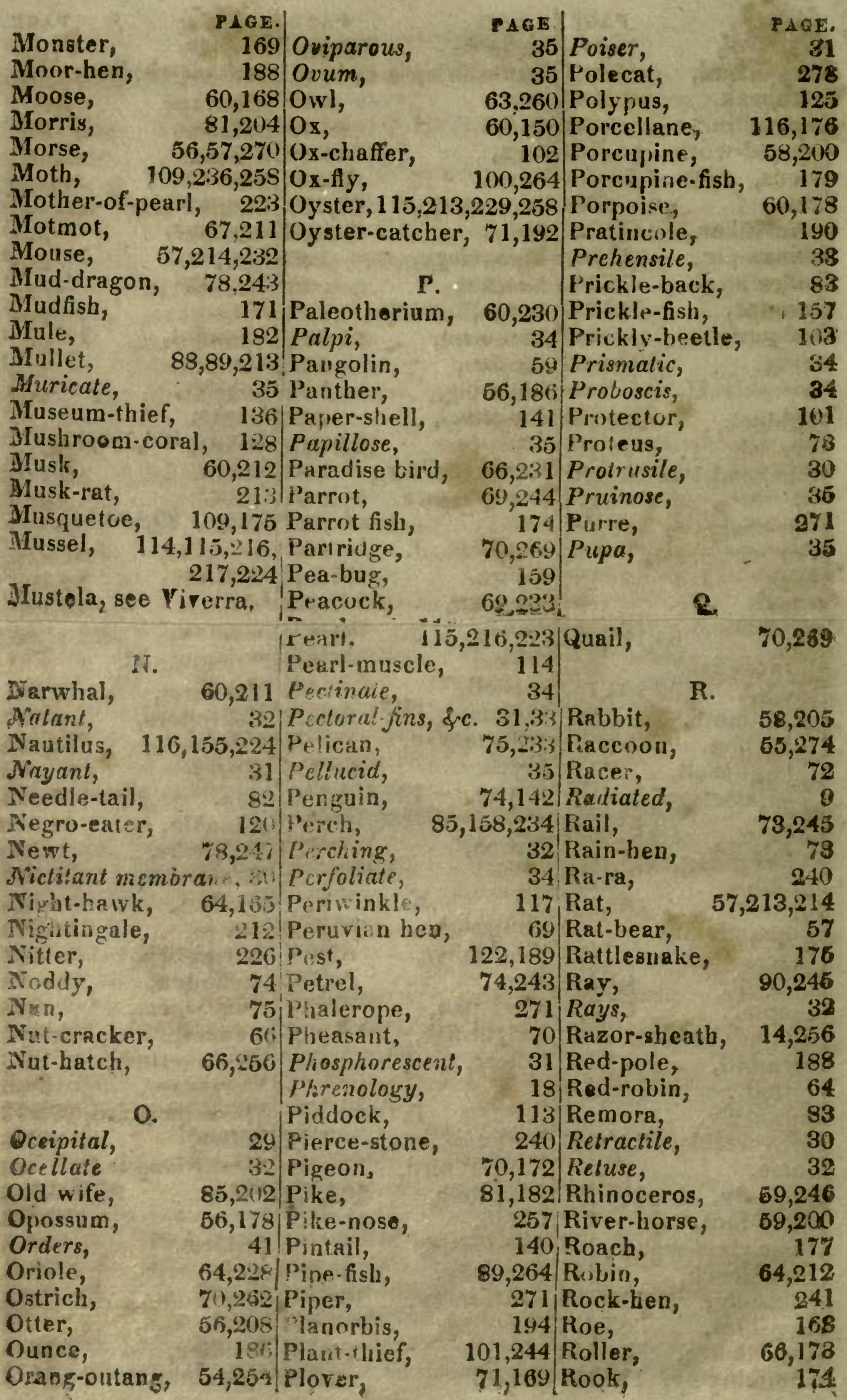




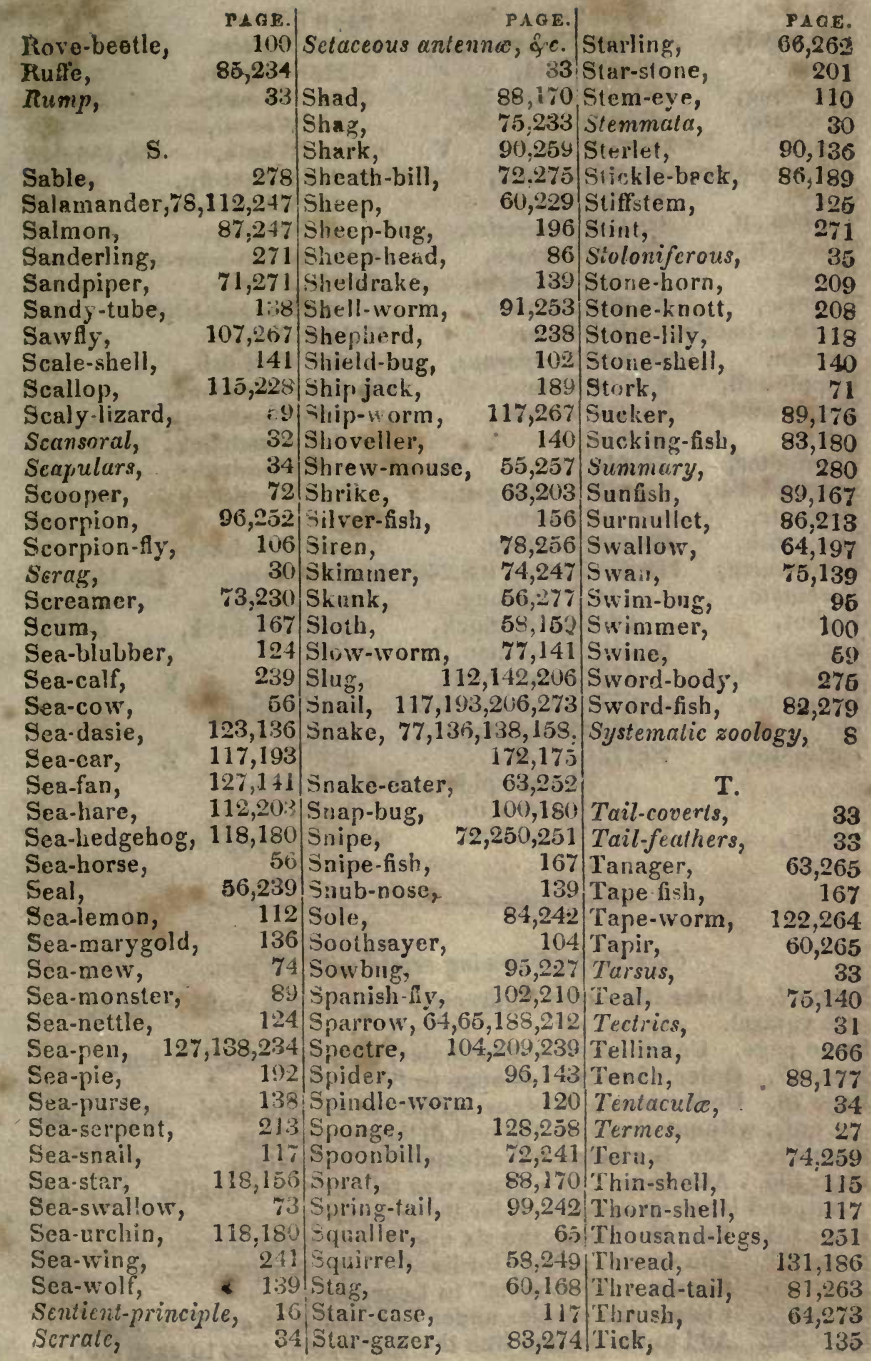




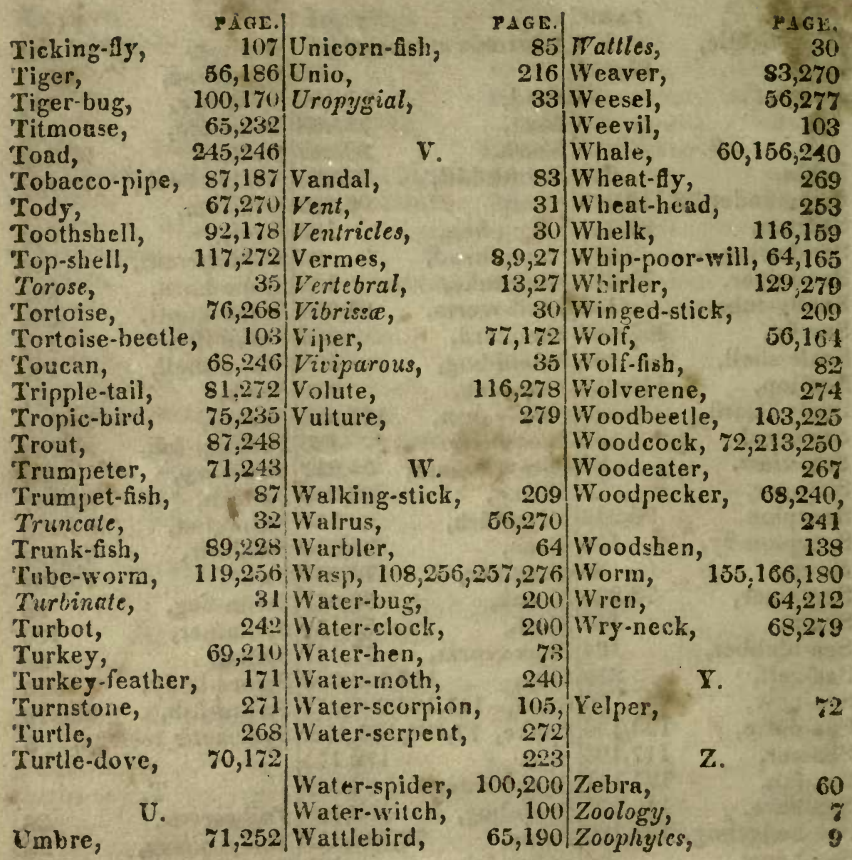

Correct the following errors with the pen.

Page 44. Under the order Thoracici, change the word "rertebral" to ventral.

Same page. Under order Abdominales, change "long" to bony.

Page 47. Order "Sutoria," change to Suctoria.

Page 78. Under genus Proteus, strike out all line third, and add the words, without claws, to the end of the description.

Page 100. Sec. B. change "luminated" to laminated.

Page 135. Acanthus. This genus was taken from Fringilla. Cross it out, and leave its species under the old genus.

Page 151. Sec. M. From the six upper dots strike out one pair.

Page 191. The species under Gordius, change to aquaticus.

Page 205. Change "Lencophia" to Leucophia.

Page 207. Change the species under Lucernaria to quadricornis.

Page 243. Add to the bottoun line the words, four toes to each foot. 
Nx iestarichave

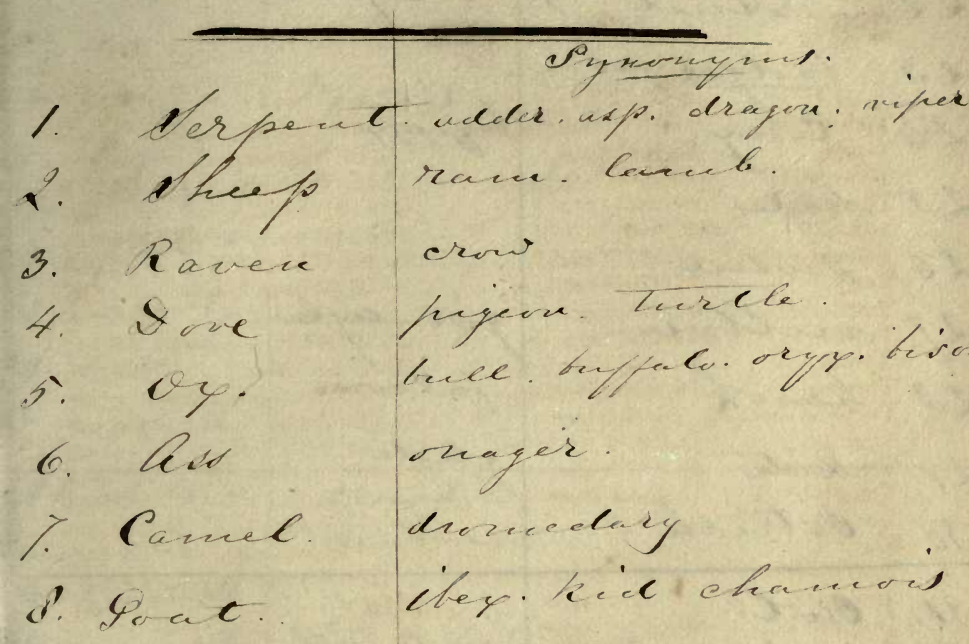

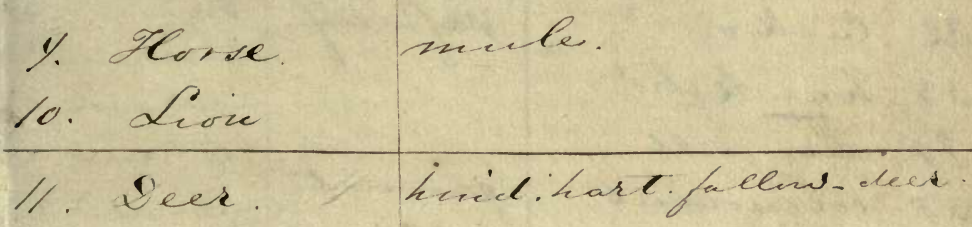

12. Italf.

13. If cille.

14. Inog

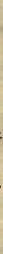

io dog

19 quace

(1) everat 4 


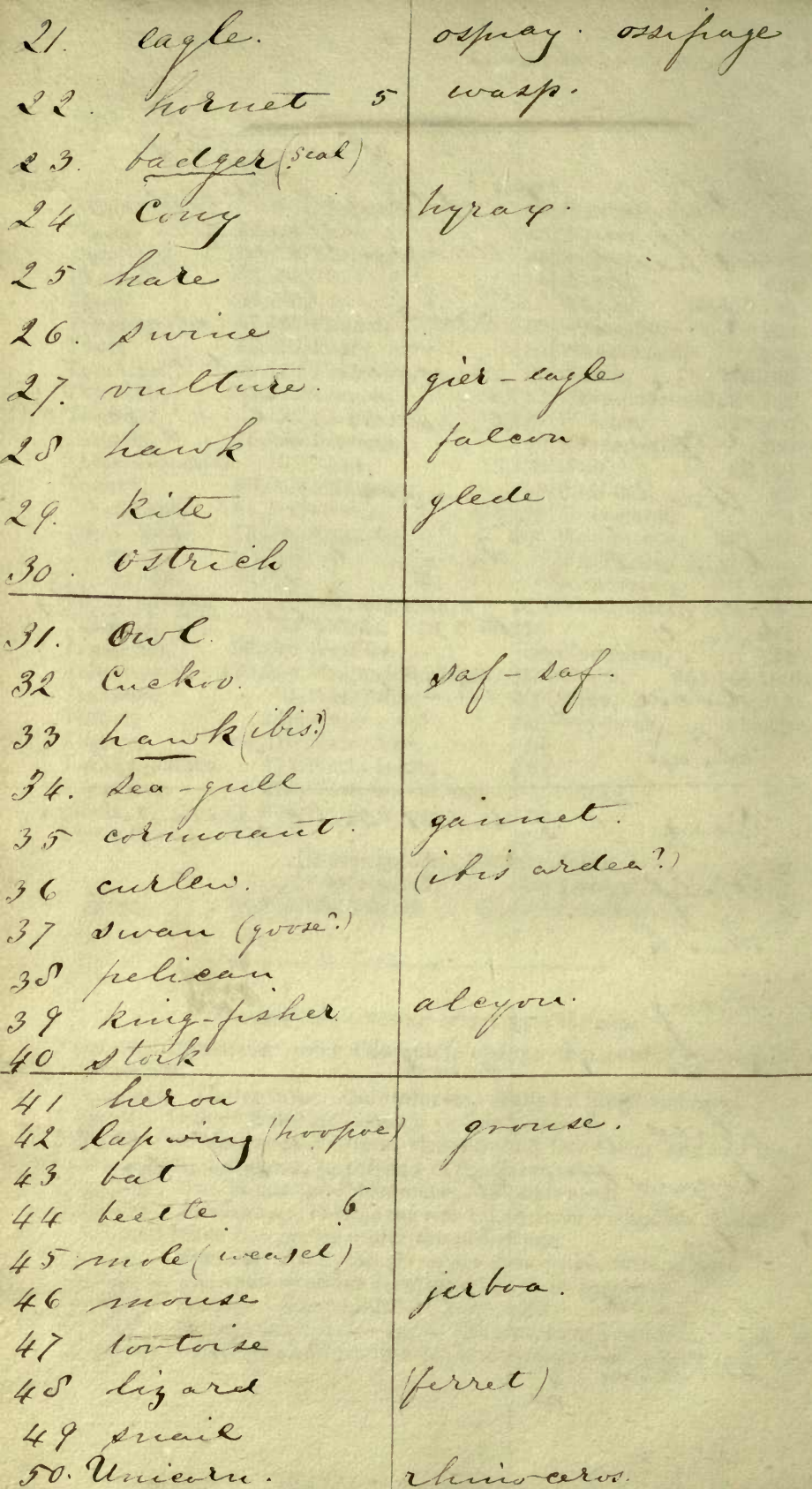


Yyer $Y$

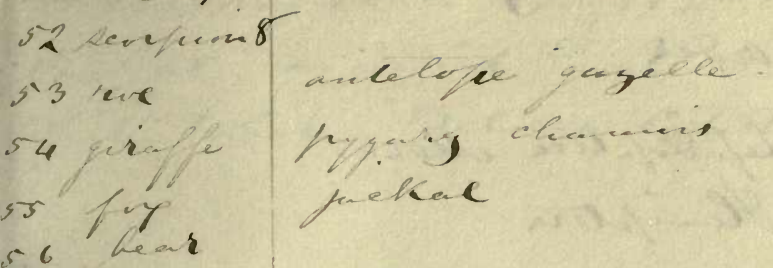

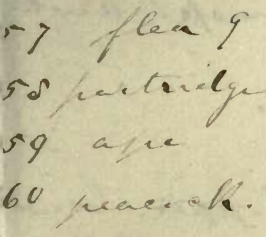

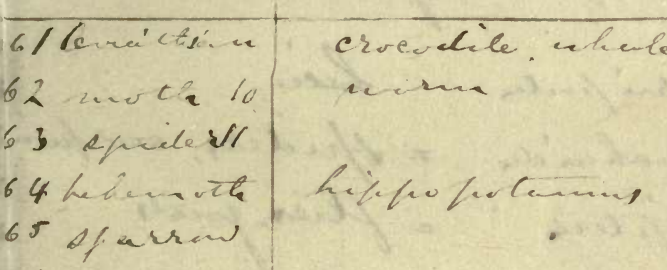

:6 Anvelens

6) a.c 12

Gs hape-Ceeds 13

693 bu

'o Cec/uaral

$\geqslant$ fictarn

72 crean

73 shinda" "whale"

14 Len

70 by ing

heokgekay?

), Inan

"s wetered tirel" 


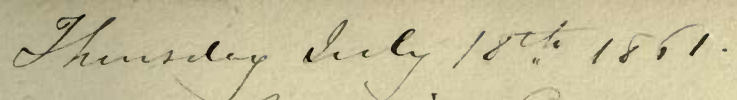

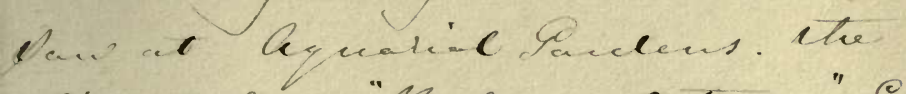

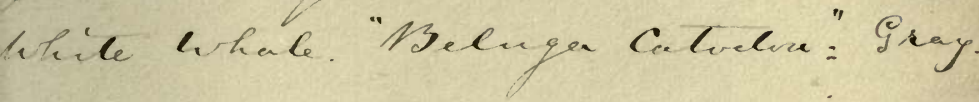





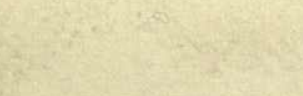







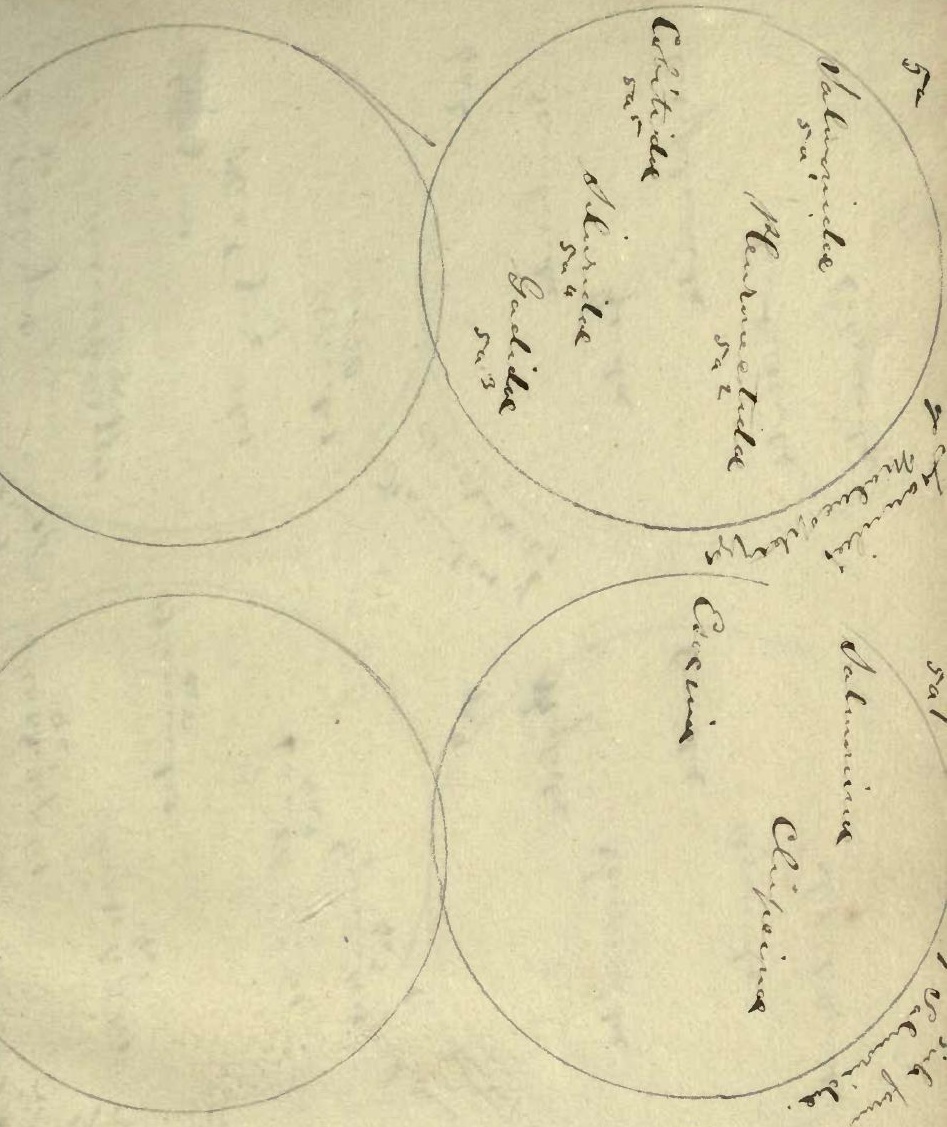




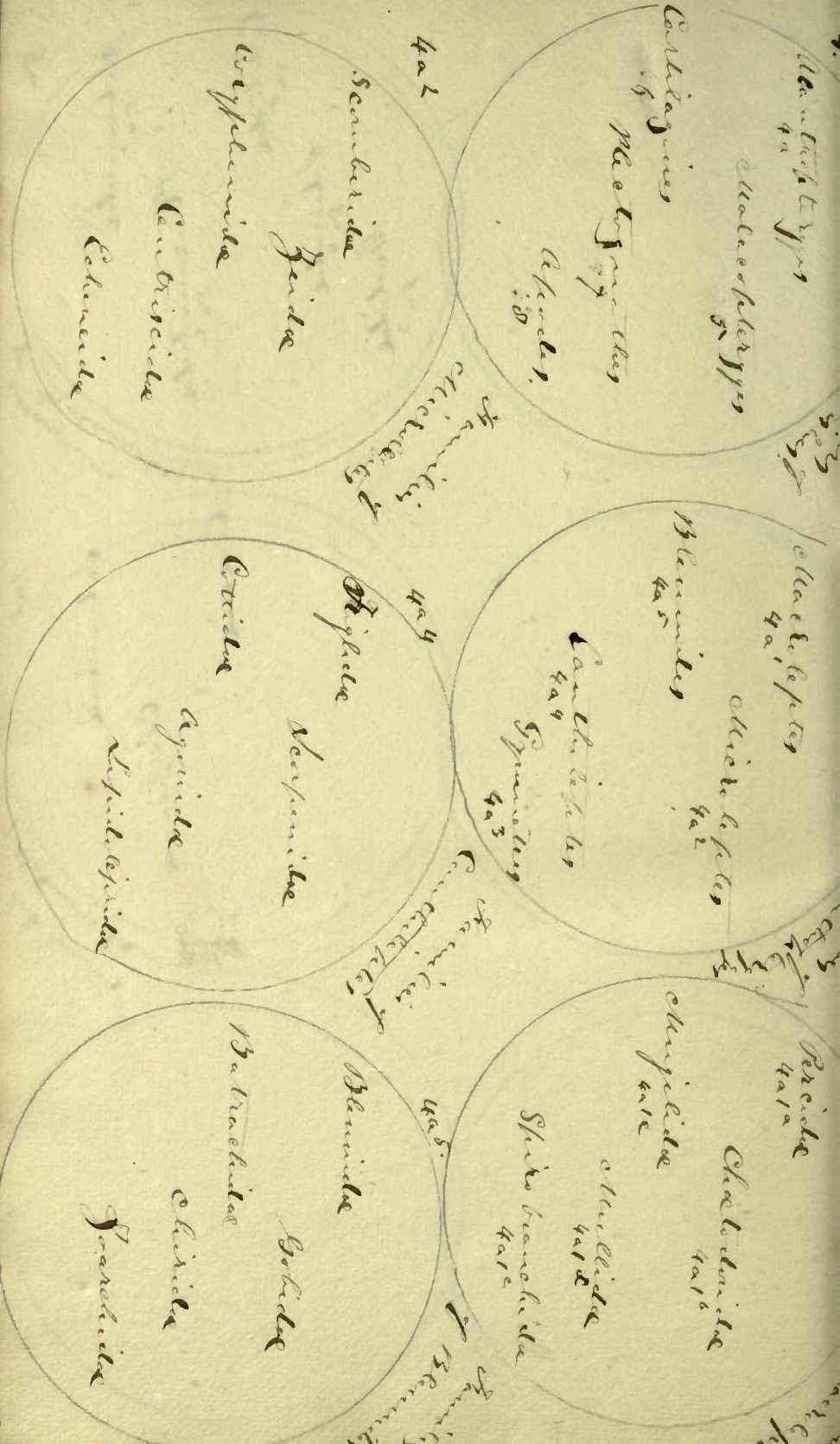


25

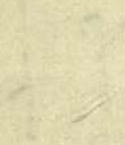




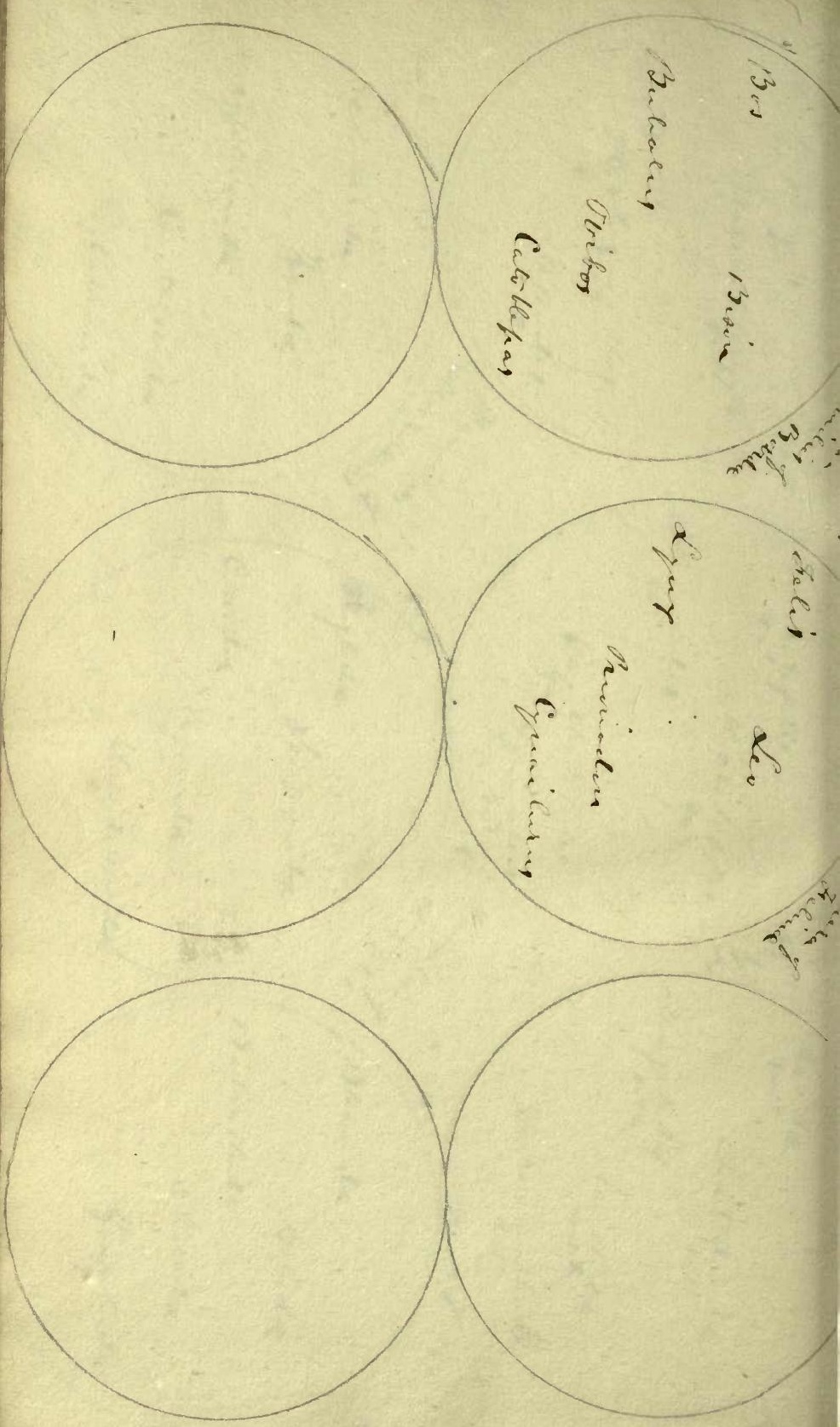




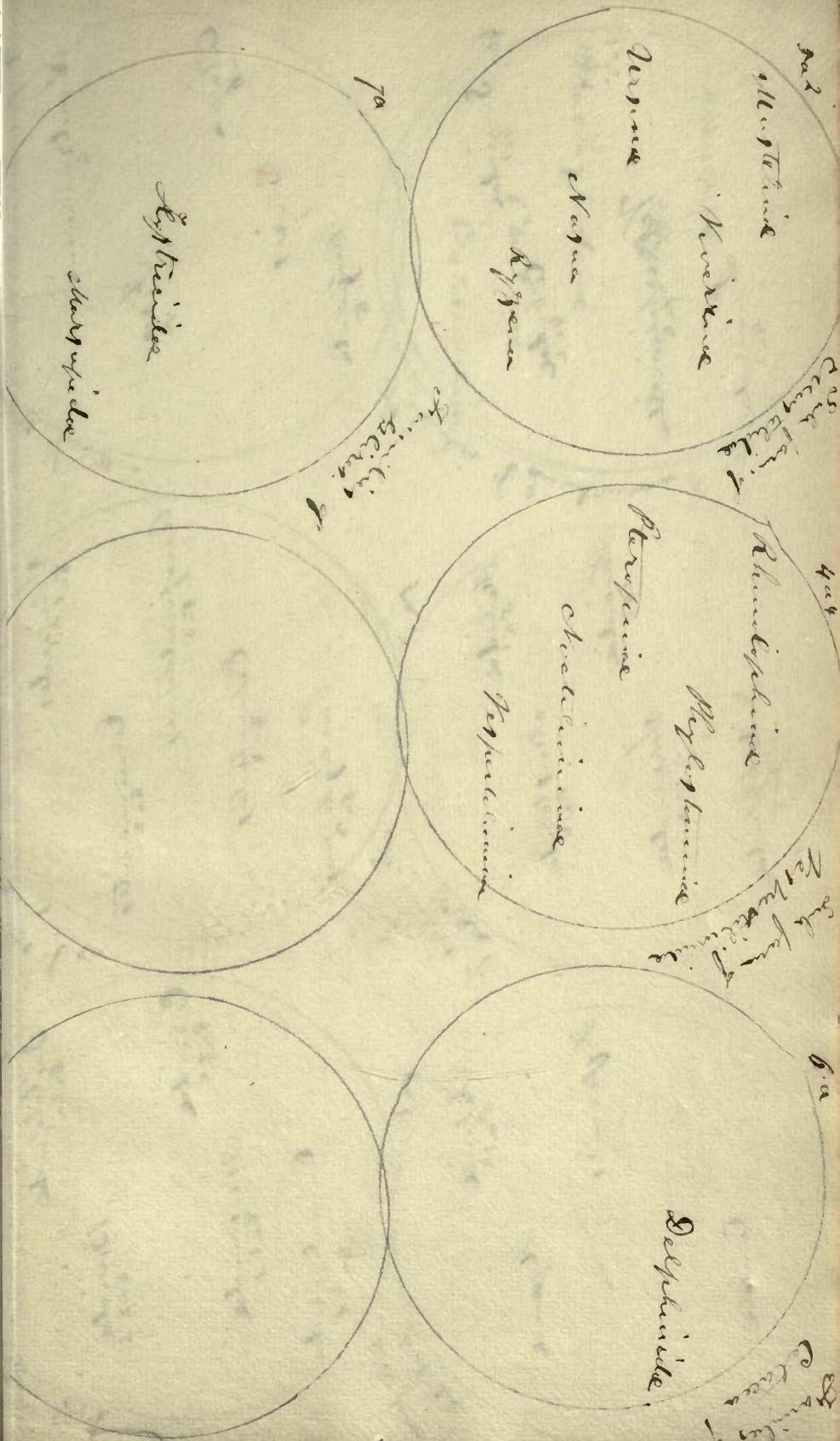




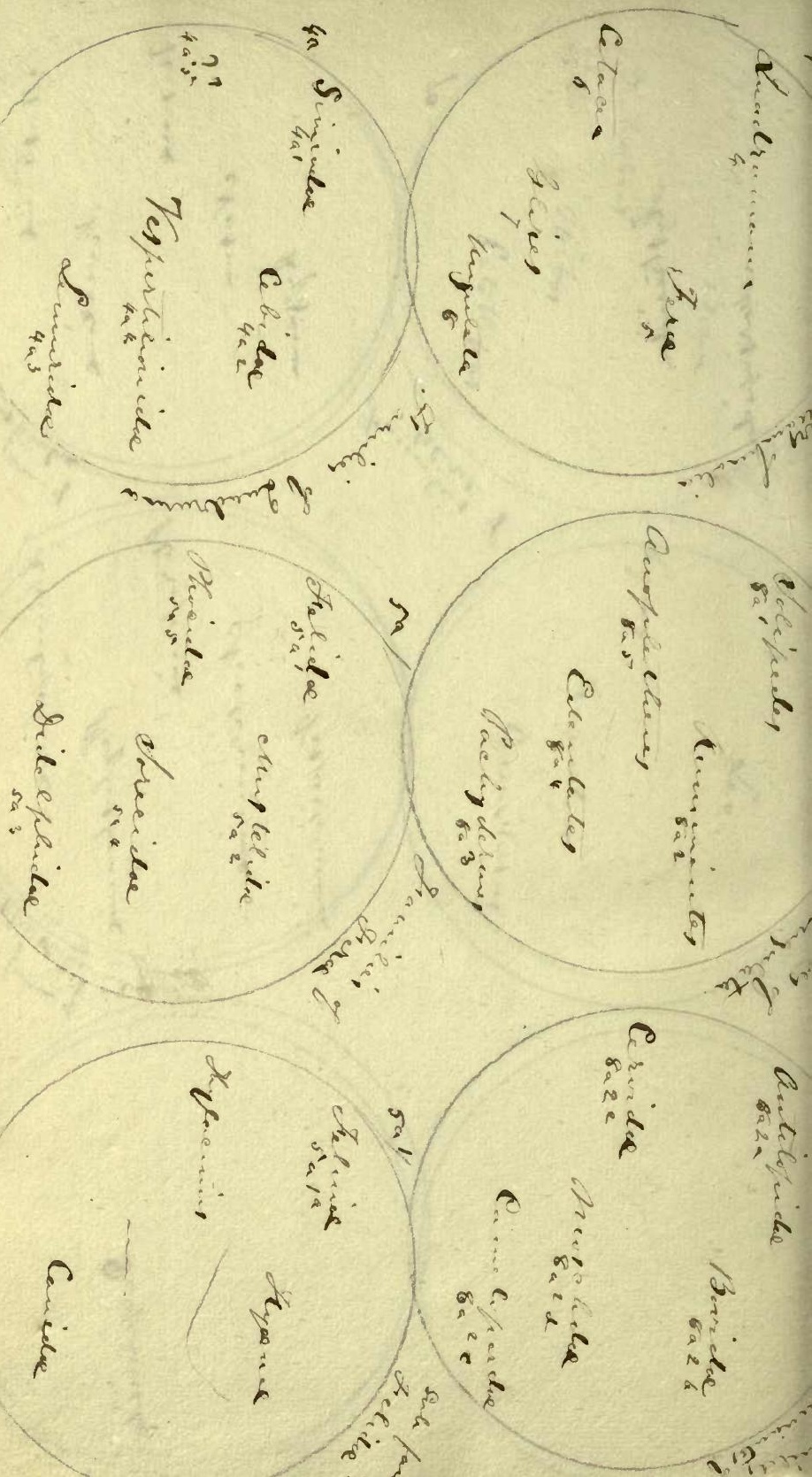




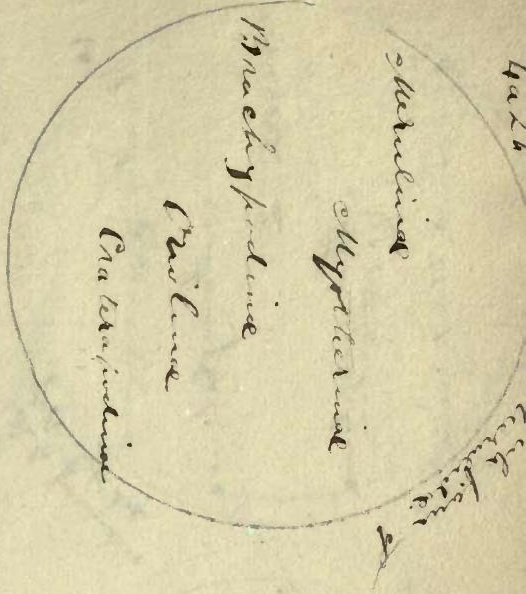




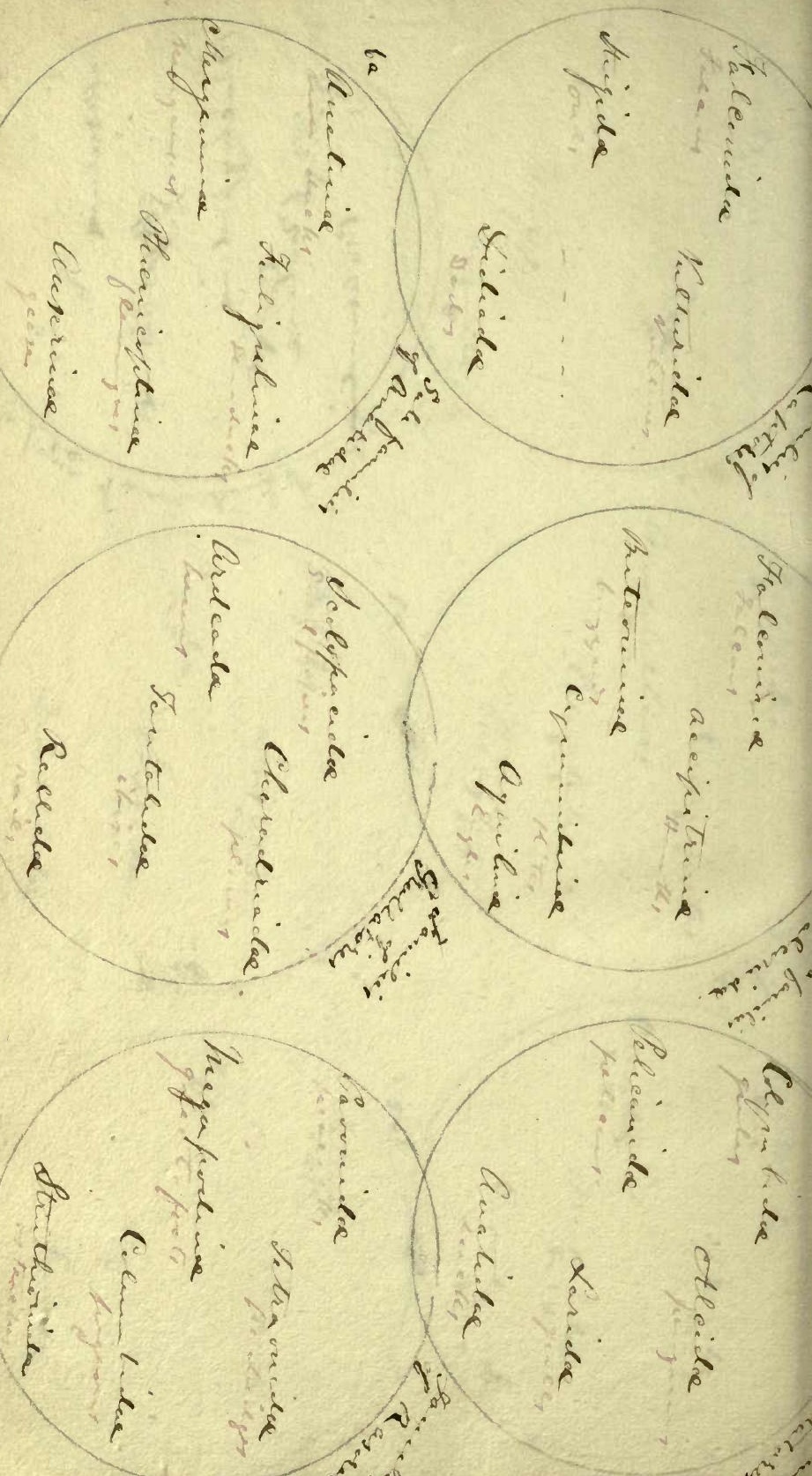




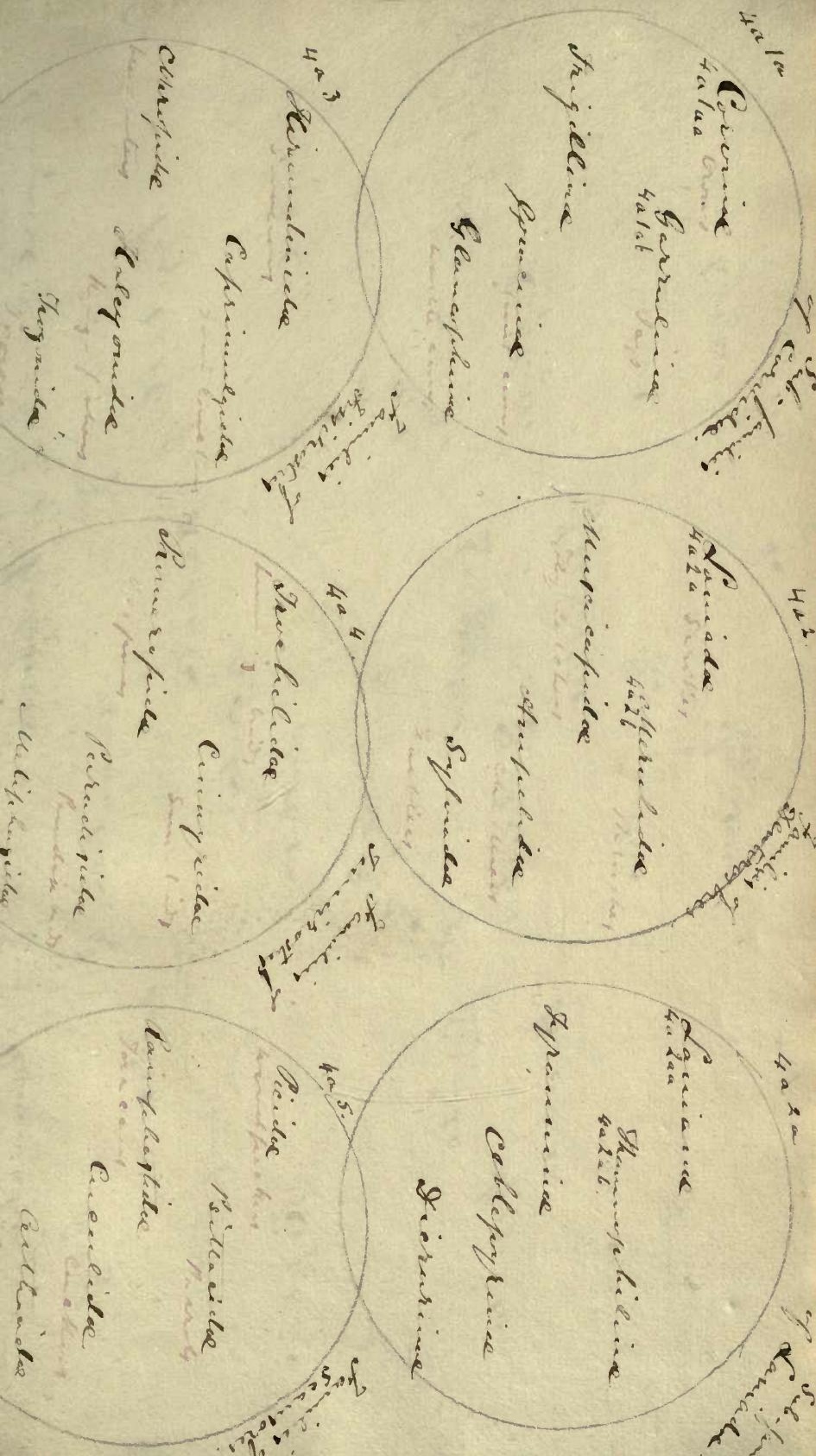



苜

?

ग

ก

든

.

.

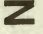

-

m

7

ग

政

皇

元 

